Maria Goretti Fernandes Izabela Souza da Silva

Insights Sobre Neuromarketing e Neurociência

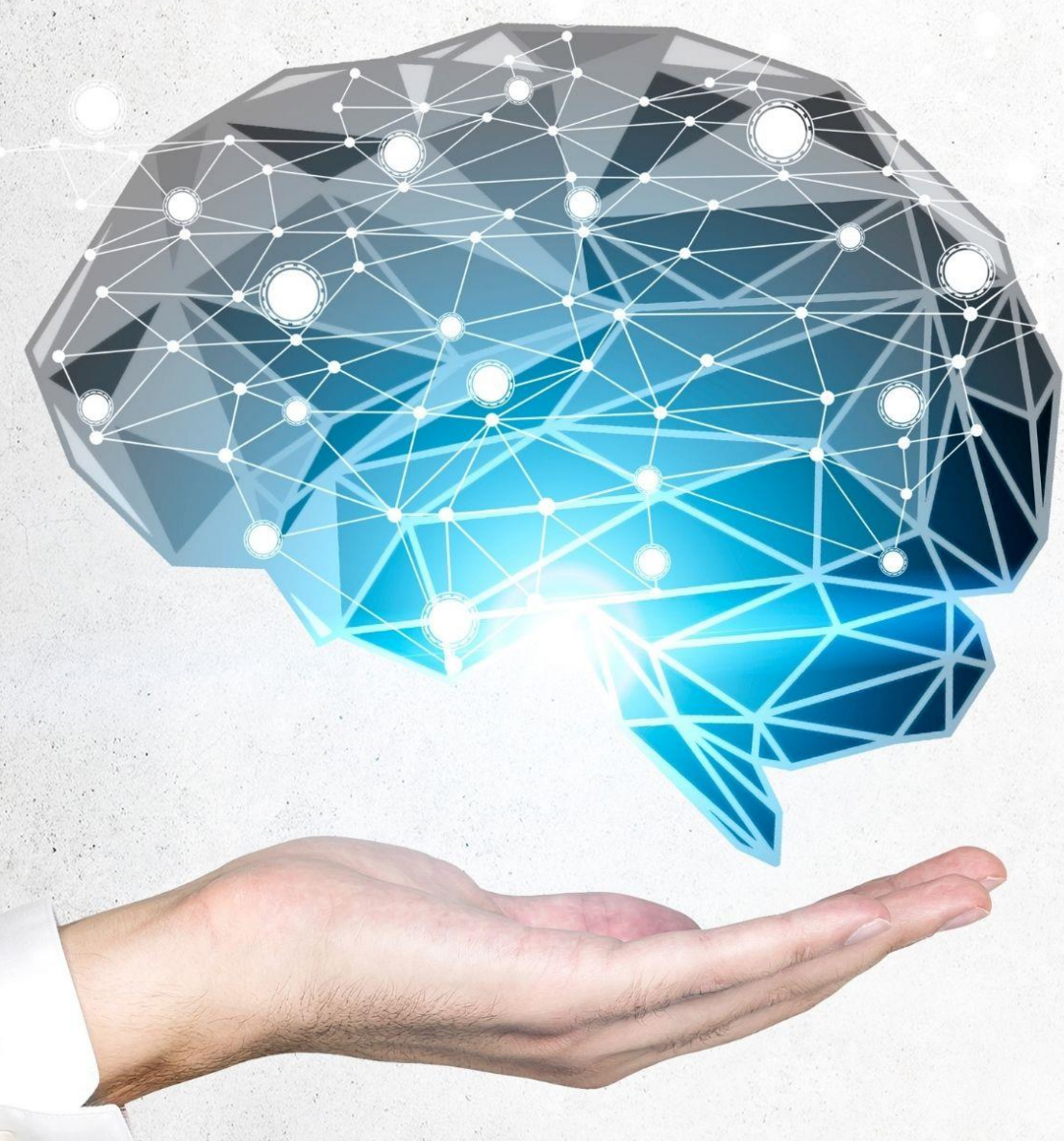

chawking 2021 
ORGANIZADORES:

MARIA GORETTI FERNANDES

IZABELA SOUZA DA SILVA

\section{INSIGHTS SOBRE NEUROMARKETING E NEUROCIÊNCIA}

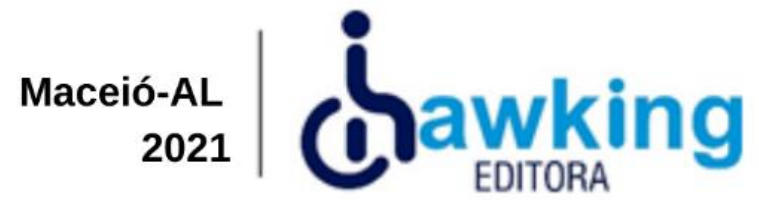


DIREÇÃO EDITORIAL: Betijane Soares de Barros REVISÃO ORTOGRÁFICA: Próprios Autores

DIAGRAMAÇÃO: Bruna Natalia de Freitas Silva

DESIGNER DE CAPA: Editora Hawking

IMAGENS DE CAPA: canva.com

O padrão ortográfico, o sistema de citações e referências bibliográficas são prerrogativas do autor. Da mesma forma, o conteúdo da obra é de inteira e exclusiva responsabilidade de seu autor.

\section{Cc) Compative $\begin{aligned} & \text { Todos os livros publicados pela Editora } \\ & \text { Hawking estão sob os direitos da Creative } \\ & \text { Commons }\end{aligned}$}

https://creativecommons.org/licenses/by/4.0/deed.pt_BR

\section{Editora HAWKING}

Rua Luiz Clemente de Vasconcelos, 725b. Clima Bom. Maceió-AL. CEP 57071-040

www.editorahawking.com.br

editorahawking@gmail.com

Dados Internacionais de Catalogação na Publicação (CIP)

Catalogação na publicação

Elaborada por Bibliotecária Janaina Ramos - CRB-8/9166

I59

Alexandre José Araújo Pereira; Ana Gabriela Lopes

Fernandes; Égon José Mateus Celestino; Elenilton Correia de Souza; Ivana Soares Barros; Ivan Lucas Duarte dos Santos; Izabela Souza da Silva; João Adriano Correia Santos; José Jailton Ribeiro; Maria Goretti Fernandes; Paloma Daniele de Oliveira Santos; Paulo Autran Leite Lima; Sílvia Pessoa de Freitas Pedrosa de Oliveira; Thiago Nunes de Azevedo Ferraz de Carvalho.

Insights sobre neuromarketing e neurociência / Maria Goretti Fernandes (Organizadora), Izabela Souza da Silva (Organizadora). Maceió: Hawking, 2021.

\section{Livro em PDF}


202 p.

ISBN 978-65-88220-18-4

1. Neurociência. 2. Neuromarketing. 3. Saúde. I. Fernandes, Maria Goretti (Organizadora). II. Silva, Izabela Souza da (Organizadora). III. Título.

CDD 612.8

Índice para catálogo sistemático

I. Neurociência: Neuromarketing 


\section{DIREÇÃO EDITORIAL}

Dra. Betijane Soares de Barros, Instituto Multidisciplinar de Maceió - IMAS (Brasil)

\section{CONSELHO EDITORIAL}

Dra. Adriana de Lima Mendonça/Universidade Federal de Alagoas - UFAL (Brasil), Universidade Tiradentes - UNIT (Brasil)

Dra. Ana Marlusia Alves Bomfim/ Universidade Federal de Alagoas - UFAL (Brasil)

Dra. Ana Paula Morais Carvalho Macedo /Universidade do Minho (Portugal)

Dra. Andrea Marques Vanderlei Fregadolli/Universidade Federal de Alagoas - UFAL (Brasil)

Dr. Eduardo Cabral da Silva/Centro Universitário Unifavip/Wyden (Brasil)

Dr. Fábio Luiz Fregadolli//Universidade Federal de Alagoas - UFAL (Brasil)

Dra. Maria de Lourdes Fonseca Vieira/Universidade Federal de Alagoas - UFAL (Brasil)

Dra. Jamyle Nunes de Souza Ferro/Universidade Federal de Alagoas - UFAL (Brasil) 
Dra. Laís da Costa Agra/Universidade Federal do Rio de Janeiro- UFRJ (Brasil)

Dra. Lucy Vieira da Silva Lima/Universidade Federal de Alagoas - UFAL (Brasil)

Dr. Rafael Vital dos Santos/Universidade Federal de Alagoas - UFAL (Brasil), Universidade Tiradentes - UNIT (Brasil)

Dr. Anderson de Alencar Menezes/Universidade Federal de Alagoas - UFAL (Brasil) 
IZABELA SOUZA DA SILVA - Psicóloga Clínica, Mestre em Ensino em Saúde e Tecnologia pela Universidade Estadual de Ciências da Saúde de Alagoas (UNCISAL), Doutoranda em Ciência da Propriedade Intelectual pela UFS - SE, Bolsista da CAPES.

MARIA GORETTI FERNANDES - Fisioterapeuta, Doutora em Ciências da Saúde pela Universidade Federal do Rio Grande do Norte (UFRN), Professora Adjunta da Universidade Federal de Sergipe (UFS), Professora da Disciplina de Administração e Marketing em Fisioterapia da UFS - SE. 
ALEXANDRE JOSÉ ARAÚJO PEREIRA - Psicólogo, Pós-graduado em Terapia Cognitivo Comportamental pela Faculdade Frassinetti do Recife, Especialista em Intervenção ABA para Autismo e Deficiência Intelectual pelo Centro Universitário Celso Lisboa.

\section{ANA GABRIELA LOPES FERNANDES -}

Fisioterapeuta, Especialista em Fisioterapia TraumatoOrtopédica pela Faculdade Integrada do Recife - PE, Título de Fisioterapeuta do Trabalho pelo Conselho Federal de Fisioterapia e Terapia Ocupacional.

ÉGON JOSÉ MATEUS CELESTINO - Doutorando em Ciências Contábeis pela UFPB, Mestre em Ciências Contábeis pela UFRN, Professor do Magistério Superior na Universidade Federal de Sergipe - UFS - SE.

ELENILTON CORREIA DE SOUZA - Doutorando pelo Programa de Pós-Graduação em Ciência da Saúde pela UFS - SE, Mestre pelo Programa de Pós-Graduação em Educação Física, UFS - SE, Professor Substituto do Departamento de Fisioterapia, UFS Campus Lagarto - SE, Professor de Fisioterapia e Ciências Aplicadas a Saúde UniAGES e Pesquisador em desordens músculo esqueléticas, envelhecimento e funcionalidade.

IVANA SOARES BARROS - Graduada em Direito pela Universidade Federal do Rio Grande do Norte (UFRN), Especialista em Direito Material e Processual do Trabalho 
pela Universidade Potiguar (UnP), Servidora TNS da Universidade Estadual do Rio Grande do Norte (UERN).

IVAN LUCAS DUARTE DOS SANTOS - Fisioterapeuta pelo Centro Universitário Estácio do Recife, (PE).

IZABELA SOUZA DA SILVA - Psicóloga Clínica, Mestre em Ensino em Saúde e Tecnologia pela Universidade Estadual de Ciências da Saúde de Alagoas (UNCISAL), Doutoranda em Ciência da Propriedade Intelectual pela UFS - SE, Bolsista da CAPES.

JOÃO ADRIANO CORREIA SANTOS - Fisioterapeuta pelo Centro Universitário UniAGES - Paripiranga (BA), Pós-graduado em Traumato-Ortopedia pela Faculdade Ibra/Fabras, Residente Multiprofissional em Saúde do Adulto e Idoso pelo HU - UFS/Ebserh - SE.

JOSÉ JAILTON RIBEIRO - MBA em Gestão Estratégia de Pessoa (LERGN), Especialista em Psicopedagogia Pela UNINASSAU - PE, Professor efetivo da rede municipal de Natal /RN - Professor Universitário no Estado do RN.

MARIA GORETTI FERNANDES - Fisioterapeuta, Doutora em Ciências da Saúde pela Universidade Federal do Rio Grande do Norte (UFRN), Professora Adjunta da Universidade Federal de Sergipe (UFS), Professora da Disciplina de Administração e Marketing em Fisioterapia da UFS - SE. 


\section{PALOMA DANIELE DE OLIVEIRA SANTOS -}

Fisioterapeuta graduada pelo centro Universitário Maurício de Nassau Aracaju - SE.

PAULO AUTRAN LEITE LIMA - Fisioterapeuta, doutor em ciência e engenharia de materiais pela Universidade Federal de Sergipe (UFS), pós-doutor em educação e psicologia pela Universidade de Aveiro (UA/Portugal), professor de cursos da saúde do Centro Universitário Maurício de Nassau (UNINASSAU-Aracaju) e professor colaborador do mestrado em Ciências aplicadas à Saúde (UFS)

\section{SÍlVIA PESSOA DE FREITAS PEDROSA DE} OLIVEIRA - Fisioterapeuta, especialista em Terapias Manuais pela UNISUAN, Mestre em Ensino em Saúde e Tecnologia pela Universidade Estadual de Ciências da Saúde de Alagoas (UNCISAL).

THIAGO NUNES DE AZEVEDO FERRAZ DE CARVAlHo - Mestre em Saúde da Criança e do Adolescente UFPE, Professor do Centro Universitário Estácio do Recife. Especialista em Terapia Intensiva Pediátrica e Neonatal, Faculdade Redentor - RJ. Fisioterapeuta Intensivista da Secretaria de Saúde do Estado de Pernambuco, Hospital da Restauração, Recife PE. 


\section{SUMÁRIO}

CAPÍTULO 1 1

A NEUROCIÊNCIA

Maria Goretti Fernandes

Izabela Souza da silva

Paloma Daniele de Oliveira Santos

Paulo Autran Leite Lima

CAPÍTULO 2 18

A HISTÓRIA DA NEUROCIÊNCIA E DO COMPORTAMENTO

Maria Goretti Fernandes

Izabela Souza da Silva

Paloma Daniele de Oliveira Santos

Paulo Autran Leite Lima

CAPÍTULO 3

AS INFORMAÇÕES E O INCONSCIENTE

Izabela Souza da Silva

Maria Goretti Fernandes

Ana Gabriela Lopes Fernandes

Silvia Pessoa de Freitas Pedrosa de Oliveira

CAPÍTULO 4

O MARKETING SENSORIAL, AS INFORMAÇÕES E O INCONSCIENTE

Izabela Souza da Silva

Maria Goretti Fernandes 
Ana Gabriela Lopes Fernandes

Alexandre José Araújo Pereira

CAPÍTULO 5

NEUROMARKETING E A PESQUISA

Izabela Souza da Silva

Maria Soretti Fernandes

Thiago Azevedo Ferraz

Ivan Lucas Duarte dos Santos

CAPÍTULO 6 65

NEUROECONOMIA, ECONOMIA E FINANÇAS COMPORTAMENTAIS

Maria Goretti Fernandes

Izabela Souza da Silva

Égon José Mateus Celestino

Ivana Soares Barros

CAPÍTULO 7 80

A NEUROCIÊNCIA E A PESQUISA DE COMPORTAMENTO ECONÔMICO

Izabela Souza da Silva

Maria Goretti Fernandes

Égon José Mateus Celestino

Ivana Soares Barros

CAPÍTULO 8 98

PESQUISAS DE NEUROMARKETING PARA A COMUNICAÇÃO VISUAL

Izabela Souza da Silva

Maria Goretti Fernandes 
Ana Gabriela Lopes Fernandes

Elenilton Correia de Souza

João Adriano Correia Santos

CAPÍTULO 9

ESTRATÉGIAS E RESULTADOS ATRAVÉS

DONEUROMARKETING

Izabela Souza da Silva

Maria Goretti Fernandes

Silvia Pessoa de Freitas Pedrosa de Oliveira

CAPÍTULO 10 146

PLANEJAMENTO ESTRATÉGICO COM BASE NO NEUROMARKETING

Izabela Souza da Silva

Maria Goretti Fernandes

José Jailton Ribeiro

Ana Gabriela Lopes Fernandes

Silvia Pessoa de Freitas Pedrosa de Oliveira

CAPÍTULO 11

158

INFORMAÇÃO E ESTIMULAÇÃO DO

NEUROMARKETING NA INTERNET

Izabela Souza da Silva

Maria Goretti Fernandes

Ana Gabriela Lopes Fernandes

Silvia Pessoa de Freitas Pedrosa de Oliveira 


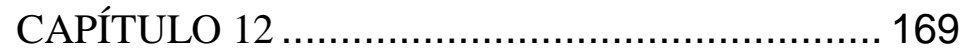

NEUROMARKETING NAS ÁREAS DO CONHECIMENTO (EDUCAÇÃO E SAÚDE)

Izabela Souza da Silva

Maria Goretti Fernandes

José Jailton Ribeiro

Ana Gabriela Lopes Fernandes 


\section{PRESENTAÇÃO}

Prezado leitor, a presente obra tem como temática central o neuromarketing e a neurociência que serão objeto de discussão de nosso estudo. Para você, a temática de neuromarketing $\mathrm{x}$ neurociência terá grande importância para qualquer profissão, principalmente para a sua atuação prática no mercado de trabalho. Tendo em vista que um dos principais objetivos das estratégias de marketing é entender melhor seu público-alvo para fornecer exatamente aquilo de que ele necessita, seja nas áreas da saúde, humanas ou tecnológica. $\mathrm{O}$ neuromarketing é a ciência que pretende entender o que se passa na cabeça das pessoas, assim como, a neurociência é o estudo científico do sistema nervoso.

Os conhecimentos adquiridos nesta edição estão diretamente ligados à necessidade de você entender como funciona a lógica do consumo dos produtos e serviços, pois é preciso compreender os desejos, os impulsos e as motivações que levam as pessoas a comprar, adquirir determinados produtos ou serviços, ou a escolher especificamente algumas marcas, assim como, é preciso estudar através da neurociência as reações que ocorrem no cérebro do consumidor ou do seu cliente.

A obra foi organizada com um pequeno resumo no final de cada capítulo para facilitar o aprendizado, contendo recomendações de leitura complementar e referências utilizadas para a elaboração do texto. Além disso, você irá aprender de forma simples como utilizar os conhecimentos do neuromarketing e da neurociência para o desenvolvimento organizacional das empresas ou do seu 
negócio (consultório, clínica, empresa, loja, estabelecimento comercial, instituição, entre outros) no que diz respeito ao planejamento estratégico e a tomada de decisões nas relações de consumo tradicionais ou no comércio eletrônico do mundo atual.

MARIA GORETTI FERNANDES IZABELA SOUZA DA SILVA 


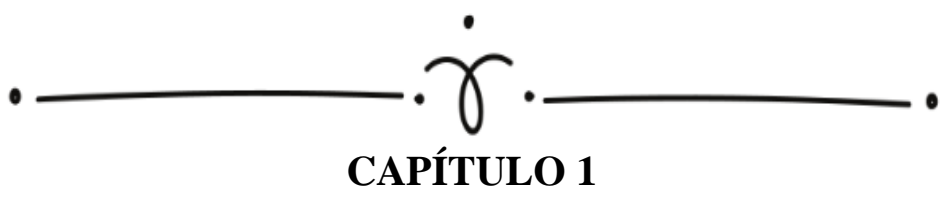

\title{
A NEUROCIÊNCIA
}

\author{
Maria Goretti Fernandes \\ Izabela Souza da silva \\ Paloma Daniele de Oliveira Santos \\ Paulo Autran Leite Lima
}

\section{INTRODUÇÃO}

Ao iniciar o estudo do neuromarketing é importante que você entenda um pouco sobre a neurociência, pois essa área do conhecimento estuda o sistema nervoso que está intimamente ligado ao objeto de estudo da nossa temática.

As bases da neuroanatomia e da neurofisiologia explicam como funciona o nosso cérebro do ponto de vista da neurociência. Portanto, você verá como os lobos e os hemisférios cerebrais funcionam correlacionando como os conhecimentos da neurociência, como ocorre o processo de aprendizagem no cérebro e o mecanismo de neuroplasticidade.

\section{1 - As bases neuroanatômicas e neurofisiológicas da neurociência}

O presente subtópico irá discutir sobre as bases neuroanatômicas e neurofisiológicas da neurociência, os conhecimentos anatômicos e fisiológicos aqui apresentados 
serão muito importantes para você, pois para entender a disciplina de neuromarketing será preciso conhecer um pouco do funcionamento do cérebro. Essa compreensão deve-se ao fato de que a neurociência investiga as funções, as estruturas e os processos de desenvolvimento do cérebro através do sistema nervoso.

O sistema nervoso apresenta três elementos importantes, que são o cérebro, a medula espinhal e os nervos periféricos (MACHADO, 2013). Todo o sistema nervoso é estrutura complexa, e o cérebro é extremamente importante para regulação de várias funções de estruturas que serão citadas posteriormente. A medula espinhal serve como meio de levar as informações do corpo para o cérebro e do cérebro para o corpo, além disso, realiza também atividades subconscientes e reflexas, esses estímulos não necessitam chegar até ao cérebro para que o comando seja processado. Já os nervos são estruturas que vão conduzir os impulsos. Todos eles trabalham em conjunto para um correto funcionamento do corpo (COSTANZO, 2014).

Segundo Meneses (2015), os nervos espinhais são compostos por 31 pares, sendo correspondentes aos segmentos medulares e os mesmos atuam em diversas regiões do corpo. 
Figura 1- Cérebro, medula e nervos.

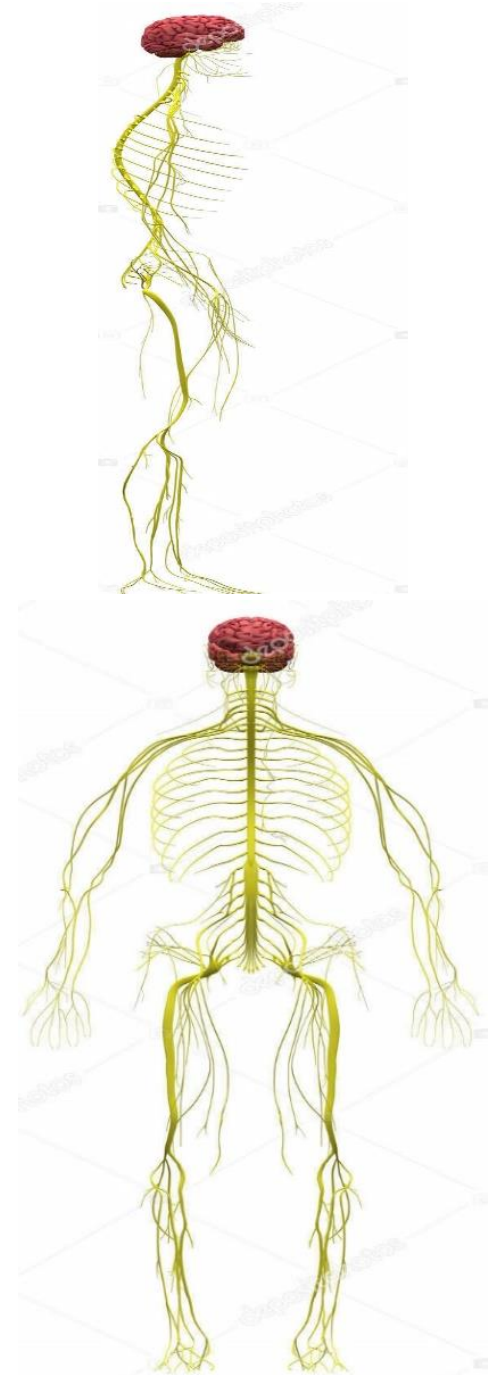

Fonte: pt.depositphotos.com 
Desta forma, qual seria o principal órgão da aprendizagem no ser humano?

O principal órgão da aprendizagem vem a ser o encéfalo que é composto por cerca de 86 bilhões de neurônios (células nervosas, que interagem entre si e com outras células) que formam as redes neurais para que possamos aprender o que é relevante para a vida. Os neurônios são células altamente excitáveis que se comunicam entre si ou com outras células por meio de uma linguagem eletroquímica (MACHADO, 2013).

\section{Figura 2- Vista Lateral do Encéfalo.}

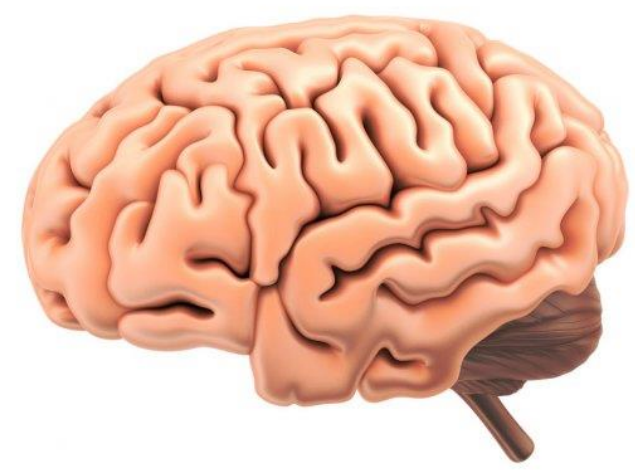

Fonte: pt.depositphotos.com

Estudando o cérebro é possível observar que na superfície do encéfalo há uma massa cinzenta composta por corpos de neurônios, essa região também chamada de córtex cerebral. Trata-se de uma região é de extrema importância, pois nela são armazenadas as informações, os 
sentidos são percebidos, os dados de estímulos externos são processados e as contrações musculares são estimuladas (VALLE, 2004).

Segundo Kolb e Whishaw (2002), as funções intelectuais, tais como: a memória, a linguagem, a atenção, as emoções, assim como ensinar e aprender, são produzidas pela atividade dos neurônios no nosso encéfalo.

\section{Figura 3- Neurônio: Dendritos, corpo e axônio envolvido pela bainha de mielina.}

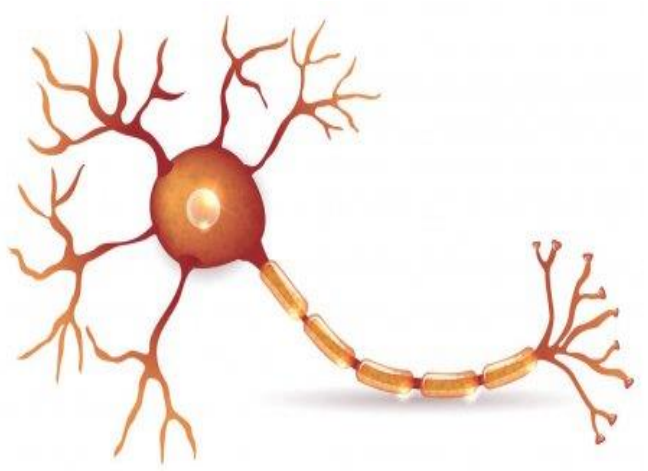

Fonte: pt.depositphotos.com

É importante destacar que o nosso comportamento depende do número de neurônios envolvidos na comunicação neural e dos seus neurotransmissores, que são substâncias químicas que modulam a atividade celular, acentuando ou inibindo a comunicação entre os neurônios. Geralmente os neurônios possuem três regiões responsáveis por funções especializadas: corpo celular, dendritos e axônios (MACHADO, 2013). 
Em geral, os dendritos recebem os impulsos que são encaminhadas para o corpo celular, local onde essa informação é processada e enviada para os axônios que por sua vez, garante com que os impulsos sigam para o próximo neurônio (SILVERTHORN, 2017). Outra estrutura importante para o neurônio é a bainha de mielina que tem função de isolante elétrico do neurônio, entre a bainha existem os nódulos de Ranvier que proporcionam o efeito saltatório dos impulsos nervosos e, consequentemente levando a informação a passar mais rápido através do axônio.

Segundo Guyton (2011), as sinapses são formas de comunicações entre os neurônios, as sinapses químicas são a maioria e acontecem por meio de um neurotransmissor que é lançado na fenda sináptica, local de encontro entre os neurônios, e em seguida é conectado ao receptor do neurônio seguinte. Já as sinapses elétricas acontecem através de junções comunicante que se ligam diretamente entre os neurônios que passam as informações pelos íons.

Essas sinapses são as conexões entre as células nervosas que compõe as diversas redes neurais e vão se tornando mais complexas, à medida que o homem interage com o meio ambiente interno e externo (GUERRA, 2011). 
Figura 4- Sinapses entre os neurônios.

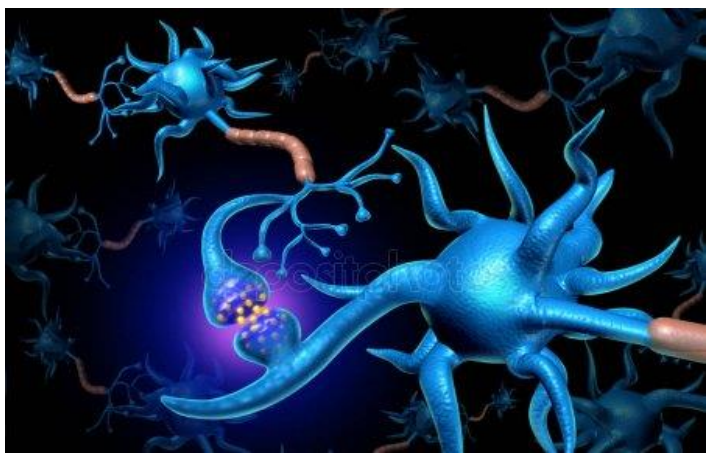

Fonte: pt.depositphotos.com

Existem três tipos de neurônios classificados quanto a sua função, os neurônios sensitivos, que recebem a informação e leva via aferente para ser processada, os neurônios motores que levam a ação até o local, e os neurônios associativos que estão presentes no sistema nervoso e estão entre os neurônios fazendo a comunicação entre eles. Já em sua forma anatômica, podemos citar os neurônios unipolares, os neurônios bipolares, os neurônios pseudounipolares e os multipolares (LENT, 2010).

\section{Figura 5- Tipos de Neurônios}

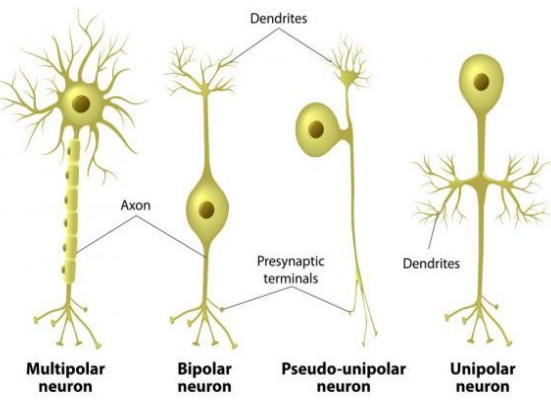

Fonte: pt.depositphotos.com 
Você pode estar se perguntando, somente os neurônios fazem parte do sistema nervoso no homem?

Não, além dos neurônios, Lent (2010) descreve que outras células também fazem parte do sistema nervoso. Elas são chamadas de células da glia e possuem funções importantes, tais como: suporte, defesa, auxílio na transmissão do impulso nervoso, produção de líquor, entre outras. No sistema nervoso central, além dos 86 bilhões de neurônios, existem 85 bilhões de células da glia, que são os astrócitos, oligodendrócitos micróglia e células ependimárias.

Figura 7- Células da Glia
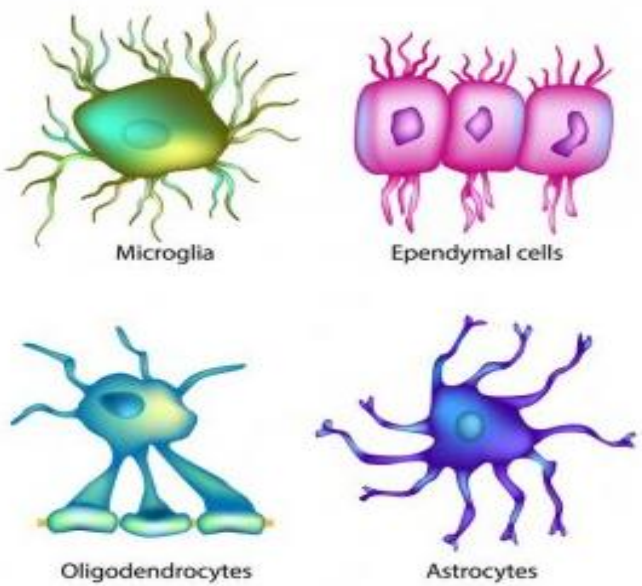

Fonte: pt.depositphotos.com

Após o que estudamos até aqui, você poderia se perguntar: Será que as células do nosso sistema nervoso possuem também funções específicas para cada uma das mesmas? 
Isso mesmo, as células da glia possuem funções variadas e específicas. Os astrócitos captam o excesso de neurotrasmissores e dão suporte para o estabelecimento dos neurônios em seus devidos lugares durante o desenvolvimento. Enquanto os oligodendrócitos produzem bainha de mielina, uma substância isolante lipoproteica que reveste os axônios, facilitando e acelerando a transmissão do impulso nervoso nos neurônios. A micróglia atua como célula de defesa, enquanto as células ependimárias produzem o líquor ou líquido encéfalo-espinhal, que reveste todo nossosistemanervoso, funcionando como uma barreira mecânica contra impactos (LENT, 2010).

A seguir veremos algumas estruturas importantes do cérebro tais como os lobos cerebrais e a divisão do cérebro em hemisférios.

\subsubsection{Os lobos cerebrais}

Segundo Machado (2013), todas as células, sejam elas neurônios ou células da glia compõem o tecido nervoso e este é a base de construção do encéfalo. $O$ encéfalo humano é um órgão formado pelo cérebro, cerebelo e o tronco encefálico. $\mathrm{O}$ encéfalo é todo o conjunto de estruturas localizadas no interior do crânio. O cérebro é responsável pelas emoções, raciocínio, aprendizagem, é a sede das sensações e movimentos voluntários. Ele possui áreas responsáveis por funções específicas e globais. O cérebro humano possui cinco divisões anatômicas chamadas de lobos cerebrais que são: lobo frontal, lobo parietal, lobo occipital, lobo temporal e lobo insular, este 
último é encontrado internamente e só poderá ser visualizado quando realizado um corte sagital do cérebro.

As regiões posteriores do córtex (os lobos occipitais) são especializadas na visão; as regiões laterais (os lobos temporais) são responsáveis pela audição e linguagem; as partes superiores (os lobos parietais) são responsáveis pelo tato e informações sinestésicas e as áreas situadas na parte anterior, isto é, os lobos frontais, estão mais bem relacionados a funções motoras e planejamento e execução de comportamentos complexos (RELVAS, 2005).

\section{Figura 8- Lobos Cerebrais.}

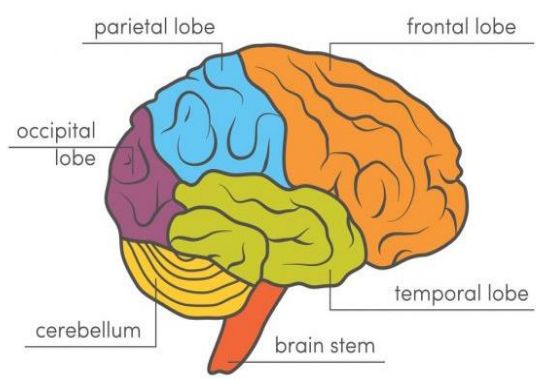

Fonte: pt.depositphotos.com

Além desta divisão anatômica, a superfície do cérebro humano apresenta depressões denominadas sulcos, que delimitam os giros cerebrais. A existência dos sulcos permite considerável aumento de superfície sem grande aumento do volume cerebral e sabe-se que cerca de dois terços da área ocupada pelo córtex cerebral estão escondidos nos sulcos (MACHADO, 2013). 


\subsubsection{Os hemisférios do cérebro}

O cérebro é formado por duas metades chamadas de hemisférios cerebrais. A metade esquerda controla o lado oposto do organismo, ou seja, a ordem dos movimentos dirigidos para o lado direito do corpo humano parte do hemisfério esquerdo. Por exemplo, uma pessoa será canhota se o hemisfério dominante dela é o lado direito do cérebro (GUERRA, 2011).

Carneiro e Cardoso (2009) explicam que apesar do cérebro trabalhar em conjunto e com os lobos interligados, cada hemisfério tem relações de aprendizagens específicas. O hemisfério esquerdo está mais ligado a raciocínio lógico, entendimentos matemáticos, explicações de questionamentos, linguagem oral, entre outras funções. $\mathrm{O}$ hemisfério direto está relacionado as emoções, a autoimagem, música, linguagem visual, criatividade e a arte.

\section{Figura 9- Hemisférios cerebrais.}

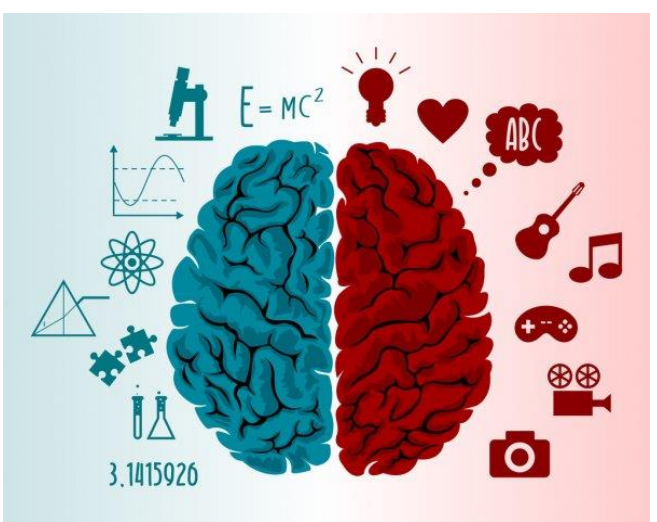

Fonte: pt.depositphotos.com. 
Pode-se dizer que o nosso cérebro é o centro de todos os nossos comportamentos, sendo que o hemisfério direito e o hemisfério esquerdo, mantêm conexões recíprocas. Já sabemos que cada tipo de habilidade ou de comportamento é relacionado a uma área do cérebro em particular (RELVAS, 2005).

\subsubsection{Aprendizagem através do cérebro e a neuroplasticidade}

O processo de aprendizagem do cérebro é bastante complexo e ao discutirmos sobre qualquer disciplina ou capítulo, temos uma grande preocupação como o conteúdo será aprendido. Nesse conteúdo, você irá aprender como esse processo ocorre, irá ficar por dentro de um termo muito atual que tem profunda correlação com a aprendizagem e que recebe o nome de neuroplasticidade.

\section{Você, já pode ter se perguntado, como é o processo de aprendizagem no cérebro humano?}

Podemos responder a essa questão com o seguinte exemplo: uma criança que não foi estimulada durante a sua infância poderá apresentar dificuldade de aprendizagem. Neste caso o encéfalo dessa criança não se desenvolveu plenamente e não pode alcançar toda a sua potencialidade. No futuro essa criança, para alcançar os seus objetivos de desenvolvimento e competência, precisará de estímulos bem direcionados e de estratégias alternativas de aprendizagem para poder ter chances de desenvolver as habilidades que não foram desenvolvidas em sua formação (COCH; ANSARI, 2009). 


\section{Figura 10- Criança e processo de aprendizagem}

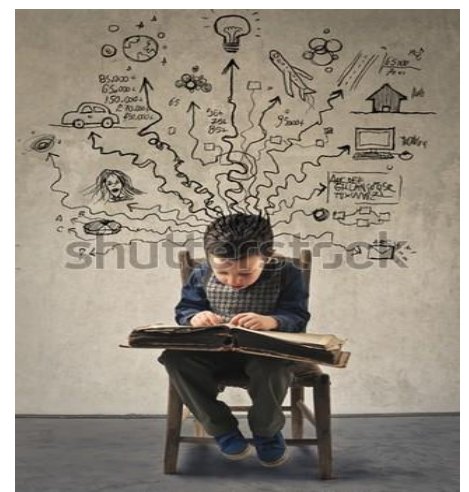

Fonte: shutterstock.com

Segundo Guerra (2011) a neuroplasticidade é a capacidade que o encéfalo possui em se reorganizar ou readaptar frente a novos estímulos, sejam eles positivos ou negativos. As sinapses ou conexões entre os neurônios se modificam durante o processo de aprendizagem, quando há evocação da memória, quando adquirimos novas habilidades. Então, a neuroplasticidade possibilita então a reorganização da estrutura do encéfalo e constitui a fundamentação neurocientífica do processo de aprendizagem.

Quando realizados estímulos repetitivos em determinada região, o sistema nervoso entende aquele estímulo como necessário, guarda na memória e passa a ativar novas áreas cerebrais para realiza-lo. Esta capacidade é importante em diversos contextos, inclusive, para pessoas que tiveram lesão em determinada região do sistema nervoso (LUNDY-EKMAN, 2004). 
As estratégias de aprendizado devem utilizar recursos que sejam multissensoriais, para ativação de múltiplas redes neurais que estabelecerão associação entre si. Se as informações/experiências forem repetidas, a atividade mais frequente dos neurônios relacionados a elas, resultará em neuroplasticidade e produzirá sinapses mais consolidadas. Aprender, entretanto, não depende só dos neurônios em suas redes neurais, das células da glia e do cérebro com seus lobos, mas, sim também, do estado de saúde em que a pessoa se encontra. É importante destacar que alguns fatores contribuem para que uma pessoa tenha $o$ encéfalo saudável: praticar regularmente atividade física; fazer uso de uma alimentação balanceada, incluindo proteínas, carboidratos, gorduras, sais minerais e vitaminas; ter um sono tranquilo, regular e satisfatório; praticar o bom humor e otimismo e manter a mente em constante funcionamento, aprendendo algo novo a cada dia $(\mathrm{COCH}$; ANSARI, 2009).

\section{O que vimos neste conteúdo?}

- A neurociência construiu as suas bases na neuroanatomia e neurofisiologia do cérebro;

- O estudo funcional do cérebro possibilita uma melhor compreensão do sistema nervoso;

- A neuroplasticidade é a capacidade que o encéfalo possui em se reorganizar ou readaptar frente a novos estímulos, sejam eles positivos ou negativos; 
- As estratégias de aprendizado devem utilizar recursos que sejam multissensoriais, para ativação de múltiplas redes neurais.

\section{Leitura complementar}

COHEN, H. S. Neurociências para fisioterapeutas, incluindo correlações clínicas. 2. ed. São Paulo: Manole, 2001.

Esse livro é importante para aprofundar os conhecimentos sobre o cérebro.

DAMASIO, A. R. O erro de Descartes: emoção, razão e o cérebro humano. São Paulo: Companhia das Letras, 1996.

Os capítulos dessa obra explicam a correlação do cérebro com a emoção e a razão.

\section{REFERÊNCIAS}

CARNEIRO, R. R.; CARDOSO, F. B. Estimulação do desenvolvimento de competências funcionais hemisféricas em escolares com dificuldades de atenção: uma perspectiva neuropsicopedagógica. Revista Psicopedagogia, São Paulo, v. 26, n. 81, p. 458-469, 2009.

COCH, D.; ANSARI, D. Thinking about mechanisms is crucial to connecting neuroscience and education. Cortex, v. 45, n. 4, 546-547, apr. 2009. 
COSTANZO, L. S. Fisiologia. Tradução de Denise Costa Rodrigues. 5. ed. Rio de Janeiro: Elsevier, 2014.

GUERRA, L. B. O diálogo entre a neurociência e a educação: da euforia aos desafios e possibilidades. Revista Interlocução, Belo Horizonte, v. 4, n. 4, p. 3-12, 2011.

GUYTON, A. C.; HALL, J. E. Tratado de Fisiologia

Médica. 12. ed. Rio de Janeiro: Elsevier, 2011.

KOLB, B. WHISHAW, I. Neurociência do

comportamento. São Paulo: Manole, 2002.

LENT, R. Cem bilhões de neurônios? Conceitos fundamentais de neurociência. 2. ed. São Paulo: Atheneu, 2010.

LUNDY-EKMAN, L. Neurociência: Fundamentos para a Reabilitação. 2. ed. Tradução de Fernando Diniz Mundim e Vilma Ribeiro de Souza Varga. Rio de Janeiro: Elsevier, 2004.

MACHADO, A. B. M.; HAERTEL, L. M.

Neuroanatomia funcional. 3. ed. São Paulo: Atheneu, 2013.

MENESES, M. S. Neuroanatomia Aplicada. 3. ed. Rio de Janeiro: Guanabara Koohan, 2015. 
RELVAS, M. P. Fundamentos biológicos da educação: despertando inteligências e afetividade no processo de aprendizagem. Rio de Janeiro: Wak, 2005.

SILVERTHORN, D. U. Fisiologia Humana: uma abordagem Integrada. 7. ed. Porto Alegre: Artmed, 2017. VALLE, L. E. L. R. do; CAPOVILLA, F. C. Capítulos multidisciplinares de neuropsicologia e aprendizagem. Ribeirão Preto: Tecmedd, 2004. 


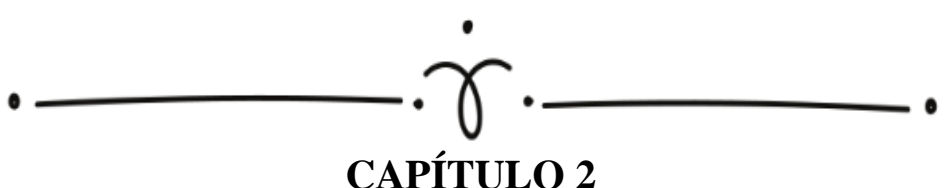

\title{
A HISTÓRIA DA NEUROCIÊNCIA E DO COMPORTAMENTO
}

\author{
Maria Goretti Fernandes \\ Izabela Souza da Silva \\ Paloma Daniele de Oliveira Santos \\ Paulo Autran Leite Lima
}

\section{INTRODUÇÃO}

No primeiro capítulo abordamos as questões referentes à neuroanatomia e a neurofisiologia cerebral com o intuito de fazer você compreender melhor como funciona o cérebro. O propósito desse capítulo é discutir a história da neurociência e o comportamento do cérebro para que você tenha um melhor entendimento sobre a neurociência e como ocorreu a evolução das descobertas nessa área. As informações sobre a evolução da neurociência também são importantes para a correlação no estudo do neuromarketing.

\section{1 início da história da neurociência}

Este é um campo de estudo relativamente novo, entretanto, possui influências de longas datas históricas que são pautadas em estudos científicos e não científicos descritos desde a filosofia grega até os modernos exames de imagens atuais. 


\section{Mas, o que de fato é neurociência?}

A neurociência é o estudo do sistema nervoso como um todo englobando várias matérias como neurologia, psiquiatria, psicologia, anatomia, radiologia, farmacologia e patologia, sendo importante na área da saúde, educação e tecnologia (VENTURA, 2010). Através da trajetória dos estudos sobre o cérebro, existiram diversas teorias de como esse sistema estaria ligado ao que acontecia com o corpo e como isso estava ou não relacionado com a alma (LENT,2008).

\section{Você, leitor, pode já ter se perguntado: Como a mente interage com o corpo?}

Esse questionamento vem gerando interesse há muitos séculos e estimulou a realização de muitas pesquisas que constituíram alicerces importantes do que hoje se entende hoje por neurociência. Os estudiosos que querem estudar os fundamentos cerebrais da atividade psicológica, devem estar preparados para estudar tanto o cérebro quanto o sistema de atividade de forma profunda (LURIA, 1992).

Segundo Finger (2001), estudiosos do século XIX tomaram conhecimento da existência de papiros egípcios com escritos médicos que descreviam 48 casos de danos causados na cabeça que poderiam alterar a coordenação motora dos lados, e, em casos mais graves afetava ambos os lados do corpo. Iniciava-se ali a história da neurociência. Para melhor entendê-la iremos estudar os fatos mais marcantes. 


\subsubsection{Grandes nomes da neurociência:}

A história da neurociência não se iniciou nos dias de hoje, mas ela tem suas bases na antiguidade quando Sócrates em 370 a.C. citou a seguinte frase: "Conhece-te a ti mesmo, pois dentro de ti reside toda sabedoria". Desse modo, a neurociência lançou seus fundamentos no método introspectivo: olhar-se para dentro de si mesmo. Contudo, sabemos que nem tudo reside dentro de nós, pois há muita coisa que aprendemos de fora que, precisamos na realidade entender como se processa essa linha divisória entre o mundo interno e o mundo externo, muitas vezes, confuso e complicado (PRESA, 2006).

De acordo com Moraes (2009), a neurociência é descrita e investigada há muitos anos, o cérebro sempre despertou interesse aos estudiosos. Na obra desse autor conhecida como o "Livro do Cérebro", há um relato cronológico dos primeiros estudos e descobertas relacionadas à área.

Agora poderemos ver grandes estudiosos de diversas áreas que colaboraram para a evolução da neurociência e suas conquistas:

- Imhotep (2650-2600 a.C): Dentre os vários conhecimentos, destacou-se na medicina, onde ficou conhecido pelos egípcios como primeiro grande médico. Sua colaboração para esta área é através de papiros que muitos autores acreditam que foram feitos pelo próprio Imhotep, onde eram descritas lesões em várias regiões do corpo, incluindo na cabeça. Além disso, descreve diversas 
estruturas da região cerebral e tem o sistema nervoso central como regulador das funções corporais, demonstrando a importância das estruturas (CORRADI; YOUNG, 2016). Apesar desta informação é notável através dos achados que os egípcios não acreditavam que o cérebro tinha tamanha importância já que, no processo de mumificação o mesmo era retirado através das narinas e dissolvido, os egípcios acreditava mais na importância do coração (TIEPPO, 2019).

- Hipócrates (460-370): Médico grego, considerado o pai da medicina, autor de diversos tratados médicos sobre o cérebro. Além de citar, através de suas obras os distúrbios relacionados a fala, o movimento e paralisias outras patologias neurológicas, levando a um conceito que o cérebro era responsável por afecções do corpo, também descreveu a trepanação como cura para lesões no crânio (CASTRO; LANDEIRA-FERNANDEZ, 2011).

- $\quad$ Platão (427-347 a.C): Filosofo que acreditava que a alma era dividida em três partes (lógica, espirituosa e apetite) (PLATÃO, 2014).

- Aristóteles (384-322): Acreditava que a consciência estava no coração e não no cérebro (ARISTÓTELES, 2020).

- $\quad$ Herophilus (335-280 a.C) e Erasistratus (310-250 a.C): eram anatomistas e médicos, tiveram grande papel no estudo da anatomia por meio de dissecções de cadáveres humanos e de animais, fazendo comparações e se 
aprofundando no cérebro, criando teorias sobre os ventrículos cerebrais, além de estudos sobre os nervos. Herophilos ficou conhecido como pai da anatomia, enquanto Erasistratus como pai da fisiologia (REVERÓN, 2008).

- $\quad$ Galeno (130-201 d.C.): esteve muito ligado aos estudos de Herophilus e Erasistratus. Reuniu conhecimentos sobre a anatomia que perduraram por vários anos e serviu como base para diversos nomes conhecidos, porém, não esteve ligado a dissecção humana. Questionou, assim como outros estudiosos, a função dos ventrículos cerebrais, relacionando-os com espíritos animais, que seria uma forma de descrever a funções mentais. Também estudou sobre as meninges, nervos, tendões e diversas outras regiões (CASTRO; LANDEIRA-FERNANDEZ, 2011).

De acordo com os estudos de Zimmer (2004), Galeno acreditava ter encontrado a sustentação do trio de almas de Platão. Ele considerava a alma vegetativa do fígado, como sendo responsável pelo prazer e pelos desejos, a alma vital do coração, produtora das paixões e da coragem e a alma da cabeça era racional. Em torno de 199 da era cristã, a medicina de Galeno foi absorvida pelas doutrinas do Cristianismo que, por sua vez, acreditavam que a alma, era a própria vida, residindo no sangue e desaparecendo por ocasião da morte. Muitos filósofos de Roma não aceitavam as ideias de Galeno sobre o cérebro, preferindo as teorias sobre o coração da autoria de Aristóteles. Eles gostavam de 
chamar a atenção para o fato de que a fala vinha do peito, o que significa que sua origem deveria estar no coração.

Estudiosos como Galeno, Nemesius (Bispo de Emesa), Gregor Reisch (Escritor) entre outros, questionaram a real função de locais como os ventrículos cerebrais, eles são muito citados como região que servia como ligação com espíritos e com a alma, sendo comparados pelo clero da igreja como apresentando ligação com a santíssima Trindade (LENT, 2008).

É notável que o estudo entre a mente, coração, corpo e alma chamam atenção desde muitos séculos atrás e que isso ocorreu em diferentes civilizações importantes. A necessidade de sempre compreender todos os aspectos das características humanas foi crescendo cada vez mais até se tornar hoje o que chamamos de neurociência. Continuaremos vendo outros nomes importantes para esse crescimento.

- Leonardo Da Vinci (1472-1519 d.C): Realizou pinturas realistas sobre o corpo humano, descreveu as estruturas o crânio, ligava o ventrículo anterior como responsável pela imaginação, o ventrículo mediano como responsável pela cognição e o ventrículo posterior responsável pela memória (LENT, 2008).

- Andreas Vesalius (1514-1564): Médico anatomista, corrigiu erros de Galeno através de dissecções de cadáveres e publicou o livro De Humanis Corporis Fabrica, que elevou sua popularidade na época (GOMES; MOSCOVICI; ENGELHARDT, 2015). 
- Thomas Willis (1621-1675): Médico Inglês, autor em um importante livro da neurociência denominado Cerebri Anatomie, que explorou assuntos além da anatomia. Apesar do conceito de que os espíritos animais estavam nos ventrículos, firmava que a memória e as funções cerebrais estavam sendo controladas pelos giros, o que dava uma atenção maior ao córtex (LENT,2008).

- $\quad$ Franz Gall (1758-1828): Com conceitos mais perto da atual realidade, esse anatomista, dividiu o cérebro em 27 regiões, onde atribuiu funções afetivas e intelectuais, abrindo espaço sobre a localização das atribuições a áreas cerebrais especificas, mesmo não agradando a outros estudiosos na época, seus conceitos foram muito mais atuais (LENT,2008).

- Paul Broca (1824-1880): Em 1861 descobriu a localização da área responsável pela linguagem, local mais tarde conhecido como área de broca no córtex lateral esquerdo, na qual uma lesão causa uma afasia motora. Seus trabalhos estavam ligados aos sucos, giros e afasias. Também foi responsável por nomear pontos anatômicos craniométricos (GUSMÃO; SILVEIRA; CABRAL FILHO, 2000).

- $\quad$ Karl Wernicke (1848-1905): Assim como Paul Broca, descreveu problemas na fala, porém, através de lesão em outra área que mais tarde seria denominada como área de Wernicke, diferente de Broca, a afasia demonstrada por Wernicke seria sensorial e não motora (TIEPPO, 2019). 
- $\quad$ Camillo Golgi (1843-1926): Famoso histologista que em 1872 descobriu a técnica de impregnação por prata, isso permitiu um avanço na visualização microscópica dos neurônios (LENT, 2008).

- Ramón y Cajal (1852-1934): Histologista espanhol que aperfeiçoou a técnica de Camilo Golgi para visualização dos neurônios, levando os dois a ganhar o prêmio Nobel. Também foi responsável por descrever os axônios e por mostrar que o cérebro não era uma rede continua e sim conjunto de unidades celulares (LENT, 2008).

- $\quad$ Theodor Shwann (1810-1882): O pai da biologia celular que descreveu a bainha de mielina e afirmou que todos os tecidos são compostos por unidades básicas, a célula (LENT, 2008).

- $\quad$ Charles Scott Sherrington (1857-1952): Pai da sinapse, descobriu o sistema inibitório e os reflexos. Ganhador do prêmio Nobel de medicina (TIEPPO, 2019).

Você já parou para pensar que foram preciso muitos séculos para que o homem pudesse iniciar uma melhor compreensão a respeito do funcionamento do cérebro?

Sim, até chegar à década dos anos 90, onde o médico psicanalista, Sigmund Freud, inicia sua jornada no inconsciente, muita coisa aconteceu.

- Korbinian Brodmann (1868-1918): Médico na área de psiquiatria e neurologia. Descritor das áreas de 
Brodmann, região composta por 52 áreas funcionais, onde 43 estão presentes no cérebro humano. Essas regiões foram identificadas através da coloração feita por técnicas de coloração de Nissl (LOUKAS et al.; 2011).

- $\quad$ Giacomo Rizzolatti (1937): Em 1992, descobriu os neurônios espelhos, sendo observado que o macaco realizava a mesma tarefa que outro individuo estivesse realizando (MORAES, 2009).

Outros nomes que são mencionados nos estudos, vale a pena citar Han Berger que esteve responsável pelo desenvolvimento dos primeiros encefalogramas; Wilder Penfield e Theodore Rasmussen que fizeram um mapeamento cortical; Roger Wolcott estudou as funções dos hemisférios e através disso, ganhou o prêmio Nobel em 1981, chegando até os dias atuais em que pesquisas continuam sendo feitas para melhor entendimento sobre a área (MORAES, 2009).

Percebe-se, com esta leitura, que através dos anos os conceitos e teorias foram mudando e melhorando, saindo de algo ligado a um ser superior e assuntos mais espirituais, evoluindo para um melhor entendimento das funções cerebrais e chegando a uma era de comprovações cientificas, indo muito além de teorias.

\subsubsection{Os marcos históricos da neurociência}

O Paciente H.M: Após uma cirurgia realizada para remover os lobos temporais e parte do hipocampo, com o objetivo de melhorar o quadro epiléptico, o paciente Henry 
Molaison perdeu completamente a capacidade de guardar as memorias do que aconteceu após a cirurgia. A inteligência e as capacidades do paciente estavam normais, afetando somente a memória presente, ele passou por diversos estudos durante sua vida, gerando diversos trabalhos para a neurociência (BOCCHI; VIANA, 2012).

O caso de Phineas Gage: Acidente onde Phineas Gage foi atingido por uma barra de ferro, na região abaixo do olho esquerdo, afetando os lobos frontais. Os relatos sobre o caso, afirmam que no momento do acidente Phineas teve convulsões, porém, após alguns minutos voltou a consciência mesmo com a abertura no crânio, ele foi atendido pelos médicos, onde foram retirados os fragmentos dos ossos do cérebro e a lesão foi coberta, teve complicações, mas em pouco tempo voltou ao trabalho. Apesar de passar por um acidente e aparentar estar bem, ele teve mudanças de comportamento, antes era uma pessoa amigável e após o acidente, tornou-se uma pessoa totalmente diferente, grosseiro e impaciente. Este caso levou os estudos a confirmarem posteriormente que, a personalidade, as emoções e o intelecto estariam ligados aos lobos frontais (MARANHÃO-FILHO, 2014).

\section{Os Primeiros Implantes Cerebrais: Experimento} realizado em 1964 por um neurologista espanhol, chamado José Delgado, onde no foi colocado um implante cerebral em um touro para que Delgado o controlasse através de ondas de rádio, essa experiência também foi realizada com outros animais testando mudar o comportamento deles (MORAES, 2009). 


\subsubsection{Os estudos em neurociência nas décadas atuais}

Apesar de tudo o que foi estudado até agora, faz-se necessário sempre evoluir. O sistema nervoso do ser humano possui funções ainda não descobertas e torna-se importante manter-se sempre atualizado aos estudos com neurociência. Com mais estudo e entendendo melhor a evolução desta área do conhecimento, novos padrões serão analisados e a compressão deste sistema se tornará menos complexo.

É importante salientar que estudos de comportamento e de neurociência possuem grandes avanços científicos. Isso foi possível através de tecnologia para mapeamento cerebral e também sobre os processos e necessidades neuropsicobiológicos (GROSS, 2009).

Atualmente, a neurociência busca aprimorar conhecimento sobre o funcionamento do sistema nervoso e a interação das suas diversas funções. Portanto, compreender como o córtex cerebral funciona é um dos passos mais importantes para aperfeiçoarmos suas funções, intervindo no processo de aprendizagem.

\section{O que vimos neste conteúdo?}

- A história deixa clara que estudar a neurociência não foi uma tarefa fácil para os pesquisadores e que desde a antiguidade com o filósofo Sócrates, o homem tem se empenhado no estudo do cérebro.

- Foram necessários milhares de anos para que algumas questões fossem desmistificadas e outras fossem 
realmente esclarecidas, uma delas era que a alma se encontrava no coração, pois a mente localizada na cabeça do homem não demonstrava capacidade para pensar, sendo incapaz de abrigar o funcionamento da alma.

- No "Livro do Cérebro", há um relato cronológico dos primeiros estudos e descobertas relacionadas à área de neurociências.

- $\quad$ O estudo do comportamento e da neurociência tem apresentado grandes avanços científicos ao longo dos anos e atualmente os estudiosos estão buscando mapear a rede neural.

\section{Leitura complementar}

CHAVAGLIA NETO, J. Neuromarketing: o efeito de ancoragem, do contexto e o papel dos neurotransmissores na mente dos consumidores. São Paulo: Baraúna, 2012.

Você deve complementar os seus estudos lendo os capítulos iniciais da leitura acima e fazendo correlação com o que apresentamos nesse conteúdo.

PERUZZO, M. As três mentes do neuromarketing. Rio de Janeiro: Alta Books, 2015.

Ao ler esse livro acrescente em suas anotações novas pesquisas e fatos que você achou interessante para complementar seus estudos.

\section{REFERÊNCIAS}


PERUZZO, M. As três mentes do neuromarketing. Rio de Janeiro: Alta Books, 2015.

Ao ler esse livro acrescente em suas anotações novas pesquisas e fatos que você achou interessante para complementar seus estudos.

\section{REFERÊNCIAS}

ARISTÓTELES. A política. São Paulo: Lafonte, 2020.

BOCCHI, J. C.; VIANA, M. B. Freud, as neurociências e uma teoria da memória. Psicologia USP, São Paulo, v. 23, n. 3, p. 481-502, 2012.

CASTRO, F. S.; LANDEIRA-FERNANDEZ, J. Alma, Corpo e a Antiga Civilização Grega: As Primeiras Observações do Funcionamento Cerebral e das Atividades Mentais. Psicologia: Reflexão e Crítica, Porto Alegre, v. 24, n. 4, p. 798-809, 2011.

CORRADI, T.; YOUNG, P. Imhotep (2700-2650 a. C.): el gran médico egípcio. Fronteras en Medicina, v. 11, n. 2 , p. 60-64, 2016.

FINGER, S. Origins of Neuroscience: A History of Explorations Into Brain Function. USA: Oxford University Press, 2001.

GOMES, M. da M.; MOSCOVICI, M.; ENGELHARDT, E. Andreas Vesalius as a renaissance innovative neuroanatomist: his $5^{\text {th }}$ centenary of birth. Arquivos de 
Neuro-Psiquiatria, São Paulo, v. 73, n. 2, p. 155-158, 2015.

GROSS, C. A. Hole in the Head: More Tales in the History of Neuroscience. Cambridge: The MIT Press, 2009.

GUSMÃO, S.; SILVEIRA, R. L.; CABRAL FILHO, G. Broca e o nascimento da moderna neurocirurgia. Arquivos de Neuro-Psiquiatria, São Paulo, v. 58, n. 4, p. 1149-1152, 2000.

LENT, R. Neurociência da mente e do comportamento. Rio de Janeiro: Guanabara Koogan, 2008.

LOUKAS, M. et al. Korbinian Brodmann (1868-1918) and His Contributions to Mapping the Cerebral Cortex. Neurosurgery, v. 68, issue 1, p. 6-11, jan. 2011.

LURIA, A. R. A construção da mente. São Paulo: Ícone, 1992.

MARANHÃO-FILHO, P. Mr. Phineas Gage e o acidente que deu novo rumo à neurologia. Revista Brasileira de Neurologia, Rio de Janeiro, v. 50, n. 2, p. 33-35, 2014.

MORAES, A. P. Q. O Livro do cérebro. São Paulo: Duetto, 2009.

PLATÃO. A república. Rio de janeiro: Novas Fronteiras, 2014. 


\section{PRESA, L. A. P. Apostila de déficit neurológico de} aprendizagem. Manaus: Faculdade Martha Falcão, 2006.

REVERÓN, R. R. Erasistratus de Ceos (310-250 A.C.):

Pionero de los estudios anatómicos. International Journal of Morphology, v. 26, n. 4, p. 823-824, 2008.

TIEPPO, C. Uma Viagem Rápida Pelo Cérebro: A Via Rápida Para Entender a Neurociência. São Paulo: Conectomus, 2019.

VENTURA, D. F. Um Retrato da Área de Neurociência e Comportamento no Brasil. Psicologia: Teoria e Pesquisa, Brasília, v. 26, n. esp., p. 123-129, 2010.

ZIMMER, C. A fantástica história do cérebro: o funcionamento do cérebro humano. Rio de Janeiro: Elsevier, 2004. 


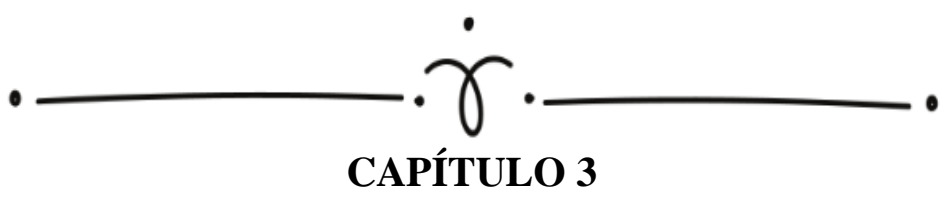

AS INFORMAÇÕES E O INCONSCIENTE

\author{
Izabela Souza da Silva \\ Maria Goretti Fernandes \\ Ana Gabriela Lopes Fernandes
}

Silvia Pessoa de Freitas Pedrosa de Oliveira

\title{
INTRODUÇÃO
}

No capítulo a seguir você irá estudar sobre as informações e o inconsciente. Iremos compreender porque o homem guarda e utiliza, sem saber, mais informações do que ele pode imaginar. Para isso teremos que buscar explicações sobre as bases empíricas que englobam desde o estudo do inconsciente na visão de Freud até os estudos da neurociência. Desse modo, o conteúdo abordado procura fazer uma correlação entre o inconsciente e, como esse, pode interferir nas questões relacionadas ao neuromarketing.

\subsection{Explicando o surgimento do inconsciente}

Durante muitos anos o homem procurou explicar a respeito do inconsciente, o pai da psicanálise, Freud foi um dos maiores estudiosos sobre o assunto; contudo, não foi somente ele que tentou buscar explicações sobre o inconsciente. 
O problema relacionado a inconsciência é realmente bastante antigo, foi investigado por vários estudiosos e, tornou-se também, a partir do século XIX, objeto de estudo de psicólogos e fisiologistas. Um dos psicólogos que estudaram sobre o capítulo foi Wilhelm Wundt e o seu estruturalismo, cujo objeto de estudo era a experiência consciente. Esse psicólogo analisou as estruturas do psiquismo humano pelo método introspectivo (ou introspecção psicológica), adotando o modelo de investigação científica das ciências naturais, a exemplo da física e da fisiologia. Para o estruturalismo o componente primordial da consciência era a sensação e, esta, classificase segundo modalidade, intensidade e duração (ROSA, 1995).

O estudioso Wundt contribuiu na definição de uma identidade para a psicologia, utilizando métodos baseados na observação, experimentação e mensuração no estudo da experiência consciente. Durante muito tempo a psicologia, enquanto ciência empírica, procurou seguir o modelo das ciências naturais, tendendo, na maioria das vezes, a reduzir as diferenças entre sujeito e objeto e adotando uma concepção naturalista. Para os naturalistas, a consciência emerge dos processos quantitativos e das relações causais que se realizam no cérebro (ROSA, 1995).

Por outro lado, a abordagem fenomenológica de Husserl defendeu a posição, na qual a consciência ocupava um lugar relevante em relação às coisas na natureza. $\mathrm{O}$ herdeiro do pensamento cartesiano, Husserl, descreve a consciência como um fenômeno qualitativo, dotado de intencionalidade, isto é, que visa a um determinado objeto, 
o psíquico é considerado um fenômeno e não uma coisa; dessa forma, o psíquico não poderia ser reduzido ao físico e a mente não poderia estar numa relação de identidade com o cérebro; portanto, para a fenomenologia de Husserl, a consciência encerra o domínio do psíquico (HUSSERL, 2000).

A concepção fenomenológica da consciência, por sua vez, passou a ser questionada pela psicanálise, uma vez que Freud estende a qualidade de "psíquico" também aos fenômenos inconscientes (FREUD, 1990). A partir das teorias de Freud, distinguiu-se a consciência em três níveis, na sua inicial divisão topográfica da mente:

- Consciente: que diz respeito à capacidade de ter percepção dos sentimentos, pensamentos, lembranças e fantasias do momento;

- $\quad$ Pré-consciente: que se relaciona com os conteúdos que podem facilmente chegar à consciência;

- Inconsciente: que se refere ao material não disponível à consciência ou ao escrutínio do indivíduo.

Você sabia que Sigmund Freud é o pai da psicanálise e o descobridor do inconsciente? Ele também é considerado o pai do inconsciente, ou seja, daquilo que não consegue ter acesso.

Isso mesmo, a abordagem psicanalítica de Freud é convicta da existência do inconsciente como um conjunto de lembranças traumáticas reprimidas, em que os impulsos 
constituem fonte de ansiedade por serem socialmente ou eticamente inaceitáveis para o indivíduo (FREUD,1990).

\subsection{A correlação do inconsciente com o neuromarketing O NEUROMARKETING}

Você, caro leitor, pode estar se perguntando nesse exato momento: por que é necessário estudar o consciente e o inconsciente no neuromarketing? Qual a sua correlação? Por que é necessário estudar a essência do comportamento do consumidor?

É necessário estudar o inconsciente e o consciente justamente pelo fato de vários estudiosos descrevem que o fator psicológico do consumo está relacionado ao inconsciente, em que a percepção e a motivação externam o que uma pessoa deseja consumir. O cérebro humano toma somente 5\% de suas decisões racionalmente, ficando $95 \%$ das decisões tomadas pelo subconsciente (KOTLER; ARMSTRONG, 2003).

Desse modo, é preciso entender que a percepção é subdividida em:

- Sensação (são os cinco sentidos: olfato, tato, audição, visão e paladar, que podem proporcionar a percepção do consumidor com relação ao produto);

- Organização (é o meio pelo qual a mente do consumidor aceita ou rejeita um produto); 
- Interpretação (é o julgamento realizado pelo consumidor, com base no que ele já vivenciou em experiências passadas).

A motivação surge quando a necessidade do consumidor está em um nível extremo, ou seja: quanto maior a necessidade, maior a urgência do consumidor em ter aquele produto; trata-se de um impulso em que a pessoa quer buscar algo a satisfaça. Dessa forma, as organizações estão sempre buscando entender o motivo pelo qual os consumidores compram. Quando esses motivos são descobertos há uma facilidade maior em se vender o produto, porém, compreender o que não está totalmente visível, como o inconsciente da pessoa, isso se torna mais complexo (KOTLER, ARMSTRONG, 2003)

E você, o que pensa sobre a necessidade das organizações em compreender e estudar os consumidores? Por que as grandes marcas estão cada vez mais estudando a respeito do neuromarketing?

Os relatos de Kotler e Armstrong (2003) citam que todos os dias que os consumidores tomam diversas decisões de compra. Por isso, grandes organizações pesquisam essas decisões detalhadamente para saber o que, onde, como, quanto, quando e por que os consumidores compram. Os profissionais de marketing podem estudar as compras dos consumidores para descobrir os diversos motivos que os levam a comprar, mas descobrir os motivos por trás do comportamento de compra da referida população, não é uma tarefa fácil, pois as respostas geralmente estão escondidas dentro da cabeça dos consumidores. 
A teoria de Sigmund Freud afirma que as pessoas não possuem consciência das forças psicológicas que formam seu comportamento, o que as torna basicamente inconscientes já que não chegam a entender por completo suas próprias motivações. Assim, quando uma pessoa avalia por exemplo, uma marca, ela não reage apenas as possibilidades que aquele produto pode lhe oferecer, mas também outros sinais menos conscientes como a forma, o tamanho, o peso, entre outros. Estes pequenos sinais inconscientes podem estimular algumas associações e emoções (KOTLER, KELLER, 2012)

Nesse conteúdo aprendemos as bases empíricas do estudo do inconsciente na visão de Freud e sua correlação com os estudos da neurociência.

É importante destacar que o inconsciente continua a influenciar no nosso comportamento, mesmo que nós não tenhamos conhecimento dessas influências subjacentes, principalmente nas relações de consumos que apresentam grandes interferências, ainda assim, o inconsciente em muitas vezes, é o grande responsável pelo desejo de consumir determinados produtos e marcas, impulsivamente.

\section{O que vimos neste conteúdo?}

- $\quad \mathrm{Na}$ teoria de Freud a mente inconsciente é um reservatório de sentimentos, pensamentos, impulsos e memórias que estão fora da nossa consciência;

- $\quad$ Aprendemos que muitos estudiosos analisaram que grande parte dos conteúdos do inconsciente são inaceitáveis 
ou desagradáveis, tais como: sensações de dor, ansiedade e conflito;

- $\quad$ Após muitos estudos ficou evidente que existem desejos inconscientes que nos fazem consumir. Além disso, a maior parte das pessoas consomem produtos e marcas, muitas vezes, sem necessidade, somente por impulso;

- $\quad$ Cérebro humano é responsável por apenas 5\% das decisões racionais, enquanto que as $95 \%$ restantes, são tomadas pelo subconsciente.

\section{Leitura complementar}

MLODINOW, L. Subliminal. New York: Pantheon Books, 2012.

KANDEL, E. Em busca da memória. São Paulo: Companhia das Letras, 2009.

Consulte os livros recomendados acima e faça um resumo sobre o que são mensagens subliminares e como a memória pode evocar o consumo de determinados produtos.

\section{REFERÊNCIAS}

FREUD, S. Esboço de psicanálise. In: FREUD, S. Edição Standard Brasileira das Obras Psicológicas Completas de Sigmund Freud. Rio de Janeiro: Imago, 1990. v. 23, p. 165-237. (Trabalho original publicado em 1940).

HUSSERL, E. Os pensadores. São Paulo: Nova Cultural, 2000. 
KOTLER, P.; ARMSTRONG, G. Princípios de marketing. São Paulo: Prentice Hall, 2003.

KOTLER, P.; KELLER, K. L. Administração de

Marketing. São Paulo: Pearson Prentice Hall, 2012.

ROSA, M. Introdução à psicologia. Petrópolis: Vozes, 1995. 


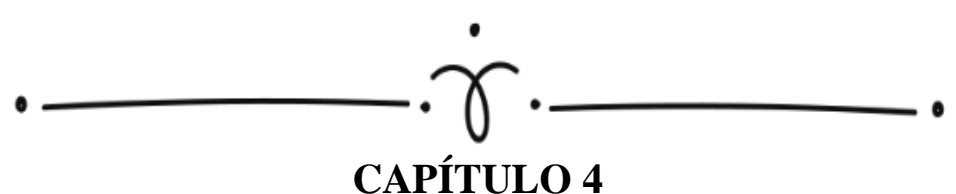

\title{
O MARKETING SENSORIAL, AS INFORMAÇÕES E O INCONSCIENTE
}

\author{
Izabela Souza da Silva \\ Maria Goretti Fernandes \\ Ana Gabriela Lopes Fernandes \\ Alexandre José Araújo Pereira
}

\section{INTRODUÇÃO}

$\mathrm{Na}$ temática a seguir iremos estudar sobre o marketing sensorial e as informações do inconsciente. Como os processos inconscientes do consumidor estudados pelo marketing sensorial influenciam na tomada de decisão, nas estratégias e nos resultados.

Os estudos em marketing sensorial apontam para a análise do cérebro do consumidor. O comportamento, a mente e os processos inconscientes dos consumidores são formas de direcionar as estratégias e campanhas publicitárias das empresas (ZALTMAN, 2003; RIES; TROUT, 2002).

Por outo lado, sabe-se que cerca de $95 \%$ dos pensamentos, emoções, aprendizados e sentimentos que impulsionam as tomadas de decisões e os comportamentos de compra dos consumidores ocorrem na mente inconsciente (WEGNER, 2002). 
O termo mente inconsciente ou inconsciente cognitivo, refere-se aos processos mentais que se desenrolam fora da consciência dos consumidores, os quais, em conjunto com os processos conscientes, criam suas experiências no mundo. As forças inconscientes incluem lembranças, imagens, sensações, metáforas e histórias em constante mutação, todas interagindo umas com as outras de maneira complexa, para moldar decisões e comportamentos (ZALTMAN, 2003).

Por exemplo, o uso de metáforas vem a ser eficaz para ajudar as pessoas a trazerem suas experiências inconscientes para o nível da consciência e em seguida transmiti-las a outros, gerando nas empresas, insights que irão auxiliam na criação de valor para seus clientes (KOPP, 1995; ZALTMAN, 2003).

Ao estudar sobre as informações do inconsciente, você pode estar se perguntando o que são as metáforas e como elas podem influenciar nas decisões de compra dos consumidores?

As metáforas são a representação de um pensamento por meio de palavras com o significado de outras, elas auxiliam os indivíduos a expressar a maneira como se sentem, como vem determinado aspecto de suas vidas, a perceberem novas conexões, a interpretarem experiências e a extraírem novos significados dessas experiências (ZALTMAN, 2003; MILLER, 2000). Estas metáforas podem influenciar a imaginação, estimular as atividades da mente humana e são importantes ferramentas para a exploração dos pensamentos e sentimentos ocultos que influenciam as decisões de compra dos consumidores 
(GOLDMAN, 1986; GIBBS JR, 1992; CAMERON; LOW, 1999).

\subsection{Os processos inconscientes e o mundo endógeno dos consumidores na tomada de decisão}

Através dos processos inconscientes buscam-se saber dos consumidores os significados mais profundos das suas respostas, os porquês das suas preferências, as suas crenças e a análise das suas experiências (BERRY; CARBONE; HAECKEL, 2002). Além disso, as decisões acontecem antes de aparentemente serem tomadas, ou seja, os julgamentos inconscientes não apenas ocorrem antes dos julgamentos conscientes, como também os orientam (BECHARA et al., 1997).

Segundo Zaltman (2003) os processos inconscientes representam o mundo endógeno dos consumidores, ou seja, são emoções, desejos internos, eventos ocorridos na infância, lembranças que influenciam os consumidores na hora de escolher um determinado produto ou marca. Por isso, os profissionais de marketing podem despertar nos consumidores sensações e experiências significativas, estimulando o interesse do mesmo pelo produto. A decisão do consumidor em comprar um produto decorre da interação entre seu o mundo endógeno (mundo interno) e o mundo exógeno (mundo externo) dos profissionais de marketing. Não compreender que o mundo do consumidor é capaz de transformar intensamente a mensagem proveniente do mundo externo, vem a ser a causa de boa parte dos fracassos no desenvolvimento de novos produtos. 
É importante lembrar que os profissionais de marketing não exploram este nível, onde a dinâmica dessa pirâmide é mais ativa.

No mercado, os processos inconscientes permitem que os indivíduos tomem decisões com mais eficiência e eficácia do que seriam capazes, caso tivessem que processar conscientemente todos os fatores relevantes (CARRUTHERS; CHAMBERLAIN, 2000).

A mente inconsciente serve como repositório de habilidades e de outras formas de conhecimento que os indivíduos adquirem de maneira consciente, mas que se tornam automáticos por meio do uso reiterado, como por exemplo as atividades de andar, amarrar os sapatos, sonhar numa segunda linguagem e saber quando o consumidor está pronto para se comprometer com uma oferta de venda (ZALTMAN, 2003).

\subsection{A mente do mercado e sua interação com o cérebro, o corpo e a sociedade}

A constante interação entre consumidores e profissionais de marketing, sob o aspecto inconsciente de suas mentes, é denomina de mente do mercado. Os profissionais de marketing devem procurar compreender os processos mentais dos seus consumidores, ou seja, devem analisar estes consumidores sob um ângulo multidisciplinar, levando em consideração ciências como a psicologia, sociologia, antropologia, neurologia, entre outras ciências (ZALTMAN, 2003).

O caráter multidisciplinar foca na interação entre o indivíduo, o seu lado inconsciente e o meio em que vive, 
traduzindo-se em quatro componentes: a mente, o cérebro, o corpo e a sociedade. $\mathrm{O}$ cérebro pode interagir com o mundo social e físico ao redor dos indivíduos; o corpo capta informações sobre o mundo, produzindo emoções e pensamentos; a sociedade, por meio das tradições sociais e culturais, desenvolve as habilidades cognitivas dos indivíduos e moldam o cérebro humano. Qualquer mudança em um dos componentes altera os demais abaixo do nível consciente, ou seja, no nível do inconsciente cognitivo (ZALTMAN, 2003).

A figura 4 demonstra claramente a interação entre os quatro componentes citados por Zaltman (2003) em seus trabalhos. Nela podemos observar que cada um dos componentes influencia e é influenciado pelos demais, por isso, são responsáveis por moldar o processo mental e o comportamento tanto dos consumidores quanto dos profissionais de marketing.

É importante lembrar que o cérebro humano muda ao longo da vida e que ele é influenciado por diversos aspectos, entre eles a cultura, o ambiente e a família, por isso, empresas como a General Motors, IBM, HewlettPackkard, Coca-Cola, Procter \& Gamble, consideram importante analisar esses quatros componentes em sua totalidade (MERZENICH, 2007; ZALTMAN, 2003).

De acordo com Le Coutre (2007) a Nestlé, indústria do setor de alimentos, desenvolve em seu centro de pesquisa (Nestle Research Center) estudos relacionados a nutrição e a percepção que o consumidor com relação a empresa. Para estas pesquisas, além dos aspectos culturais e sociais, a empresa procura analisar a fisiologia molecular 
do sabor da língua, verificando detalhes morfológicos da papila gustativa e seus reflexos no cérebro, com o intuito de entender aspectos relacionados à sensação de fome ou de saciedade. Percebe-se que a estrutura cérebro-mente-corposociedade, quando trabalhada em sua totalidade, fornece uma leitura das necessidades, satisfação e fidelidade dos consumidores favorecendo o sucesso de determinadas marcas, produtos ou serviços.

\section{O que vimos neste conteúdo?}

- $\quad$ O conjunto das dimensões que surgem pelo uso dos cinco sentidos na imagem de uma marca, produto ou serviço fortalecerá a mesma contribuindo para um melhor relacionamento com o consumidor;

- O termo mente inconsciente ou inconsciente cognitivo, refere-se aos processos mentais que se desenrolam fora da consciência dos consumidores, os quais, em conjunto com os processos conscientes, criam suas experiências no mundo;

- $\quad$ caráter multidisciplinar focando a interação entre o indivíduo, o seu lado inconsciente e o meio em que vive, se traduz em quatro componentes: a mente, o cérebro, o corpo e a sociedade;

- A empresa ao estudar a interação do cérebro do consumidor com a sua mente, seu corpo e a sociedade em que vive, irá obter sucesso em suas estratégias de venda.

\section{Leitura complementar}


LINDSTROM, M. BrandSense: segredos sensoriais por trás das coisas que compramos. 2. ed. Porto Alegre: Bookman, 2012.

LUDOVICO, N.; SANTINI, F. R. Gestão de marketing O plano de marketing como orientador das decisões. São Paulo: Saraiva, 2014. (Série gestão empresarial).

Como complemento dessa temática você deverá procurar ler a respeito dos segredos sensoriais e buscar artigos sobre o marketing sensorial.

\section{REFERÊNCIAS}

BECHARA, A. et al. Deciding Advantageously before knowing the advantageous strategy. Science, v. 275, issue 5304, p. 1293-1295, 1997.

BERRY, L. L.; CARBONE, L. P.; HAECKEL, S. H. Managing the total customer experience. MIT Sloan Management Review, v. 43, n. 3, p. 85-90, 2002.

CAMERON, L.; LOW, G. Researching and appluing metphor. Cambridge: Cambridge University Press, 1999.

CARRUTHERS, P.; CHAMBERLAIN, A. Evolution and the human mind: modularity, language and metacognition. Cambridge: Cambridge University Press, 2000 . 
GIBBS JR, R. W. Categorization and metaphor understanding. Psychological Review, v. 99, n. 3, p. 572577, 1992.

GOLDMAN, A. I. Epistemology and cognition.

Cambridge: Harvard University Press, 1986.

KOPP, R. R. Metaphor therapy: Using client-generated metaphors in psychotherapy. Nova York: Bunner/Mazel, 1995.

LE COUTRE, J. Molecular taste physiology of tongue and gut. In: NEUROSCIENCE SYMPOSIUM, 2., 2007, Natal. Anais [...]. Natal: IINN, 2007. p. 11.

MERZENICH, M. M. Cortical plasticity-based neurorehabilitation. In: NEUROSCIENCE SYMPOSIUM, 2., 2007, Natal. Anais [...]. Natal: IINN, 2007. p. 5.

MILLER, A. I. Insights of genius: Imagery and creativity in science and art. Cambridge: MIT Press, 2000.

RIES, A.; TROUT, J. Posicionamento: A batalha por sua mente. São Paulo: Pearson Makron Books, 2002.

WEGNER, D. M. The ilusion of Conscious will.

Cambridge: MIT Press, 2002.

ZALTMAN, G. Afinal, o que os clientes querem. Rio de Janeiro: Campus, 2003. 


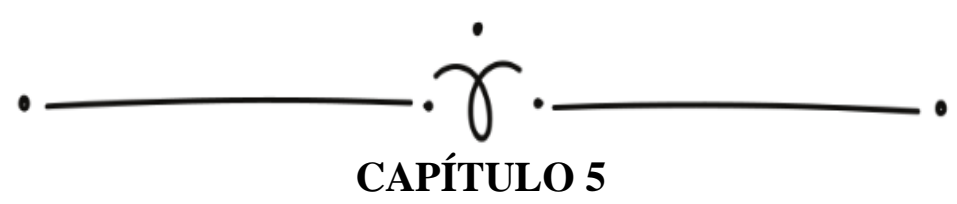

NEUROMARKETING E A PESQUISA

\author{
Izabela Souza da Silva \\ Maria Soretti Fernandes \\ Thiago Azevedo Ferraz \\ Ivan Lucas Duarte dos Santos
}

\title{
INTRODUÇÃO
}

É muito importante descrever a correlação da temática de neuromarketing com o meio científico. Desse modo, o capítulo 5 da nossa temática irá discutir a respeito da correlação da mesma com a pesquisa. Uma vez que ao pesquisar utilizando os preceitos do neuromarketing irá possibilitar as organizações empresariais a identificarem quais os fatores determinantes nas decisões de consumo.

\section{1 - As pesquisas em neuromarketing}

Atualmente o número de pesquisas que vem sendo desenvolvidas a respeito do neuromarketing tem aumentado consideravelmente. Esse fato ocorre principalmente após ter ficado claro que técnicas de neuromarketing podem identificar os fatores determinantes na decisão de consumo e com isso influenciar o mercado das finanças.

Como já vimos no tema anterior sobre neurociência. Por causa da interferência do cérebro no consumo de 
produtos ou serviços, nas organizações a própria área do marketing em si, vem se interessando mais pelas contribuições da neurociência, ao buscar entender os processos subconscientes de consumo a partir das respostas fisiológicas e da atividade cerebral (ARIELY; BERNS, 2010; DIAS, 2012; LINDSTROM, 2009; MORIN, 2011).

\section{Ao ler esse conteúdo você pode estar se perguntando: mas para que estudar as pesquisas em neuromarketing? Onde essa temática irá me favorecer profissionalmente? O que posso aprender com isso? Como o neuromarketing está diretamente ligado a esse processo?}

Para responder a todas essas perguntas podemos citar Ariely e Berns (2010), os referidos autores relatam que a pesquisa na área de marketing busca auxiliar a criação de produtos que atendam às necessidades do consumidor. Por isso, os profissionais da área buscam levantar dados relativos às preferências do cliente, antes mesmo de iniciar o desenvolvimento de novos produtos ou serviços. Contudo, como apontam os autores, os métodos tradicionais de pesquisa não conseguem captar as informações através do discurso oculto do consumidor. Ainda de acordo com estes autores, as técnicas de neuromarketing poderiam identificar os fatores determinantes na decisão de consumo, ao mesmo tempo em que se oferecem informações aprofundadas que poderiam ajudar a formular estratégias efetivas de marketing, facilitaria assim as relações de consumo e aumentando o desempenho das organizações empresariais. 
Essa opinião é reforçada pela Nielsen (...,2014), cujo portal na internet apresenta um artigo afirmando que a aplicação das técnicas neurocientíficas proporcionam um grande avanço no desenvolvimento das estratégias empresariais, ao permitir identificar de forma mais precisa a resposta do consumidor frente aos diferentes estímulos de marketing. Deixando claro que as informações obtidas diretamente do cérebro permitem melhorar, editar comerciais e esforços de Marketing para aumentar seu impacto e, ao mesmo tempo, minimizar os custos de implantação (NIELSEN..., 2014).

Há alguns anos as pesquisas de neuromarketing vem utilizando instrumentos médicos para a sua realização. Ficando cada vez mais evidente que os profissionais que desejam trabalhar nessa área, precisam de um neurocientista na sua empresa, ou de alguém que saiba muito mais do que a função do córtex pré-frontal ou a localização da amígdala. Atualmente toda pesquisa de neuromarketing utiliza um destes dois equipamentos: fMRI (Imagem por Ressonância Magnética Funcional) ou EEG (Eletroencefalografia), na sigla inglês (RIBEIRO, 2009). 


\section{Figura 10 Eletroencefalograma (EEG) e sua colocação para registro das atividades do cérebro}

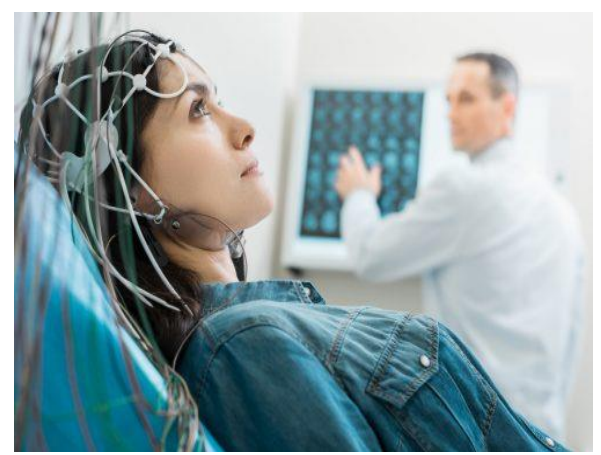

Fonte:https://maislaudo.com.br/especialidades/eletroencefalogramaeeg/

É justamente por isso, que as pesquisas em neuromarketing vem utilizando a EEG para investigar as respostas do cérebro a diversos estímulos, pois esse método de monitoramento eletrofisiológico consegue registrar a atividade elétrica do cérebro e trata-se de um método nãoinvasivo, onde os eletrodos são colocados no couro cabeludo da pessoa para captar a atividade cerebral (RIBEIRO, 2009).

Então, atualmente torna-se cada vez mais inquestionável o valor das pesquisas de neurociência voltadas para o neuromarketing. Por isso, você sabia que essas informações já foram constatadas por grandes empresas internacionais que a usam e aprovam o uso dos métodos EEG e fMRI?

Sim, muitas organizações já fizeram uso da neurociência aplicada ao marketing em diversos projetos. De acordo com Bucznski (2017), as empresas que 
recorreram as pesquisas de neuromarketing também utilizaram o EEG em suas investigações, entre estas podemos relatar:

Hyundai: procura saber o que os consumidores pensam sobre um determinado carro ou modelo antes que começar a fabricar milhares deles. Uma das pesquisas utilizada pela empresa foi feita a partir de testes de usabilidade do veículo, onde 15 mulheres e 15 homens foram colocados dentro do carro, e enquanto o usavam, eram monitorados através de um EEG para observar as atividades cerebrais. Essas atividades foram interpretadas e, através dessa interpretação, os pesquisadores observaram preferências que levavam o consumidor a uma possível decisão de compra.

Pepsico: realizou uma pesquisa utilizando duas diferentes técnicas: um grupo focal (pesquisa tradicional) e o EEG (pesquisa neurocientífica), para entender o real impacto de uma das propagandas de Cheetos nos consumidores. A propaganda consistia em uma piada, e a pesquisa de grupo focal mostrou que os participantes do grupo não haviam gostado do conteúdo da piada, isso foi o que eles verbalizaram para os pesquisadores. Porém, quando o EEG foi utilizado, os pesquisadores descobriram que na verdade, as mulheres gostavam da campanha.

Yahoo: antes de lançar uma campanha de 60 segundos na TV e no meio online, que mostrava pessoas felizes e dançantes, a Yahoo realizou uma pesquisa com EEG para avaliar como a campanha impactaria os espectadores. Depois de validada pela neurociência e 
lançada, a campanha rendeu novos usuários para a ferramenta de busca.

$\checkmark \quad$ Microsoft: a empresa investiu em pesquisas que faziam uso da metodologia do EEG, com objetivo de entender como campanhas publicitárias que apareciam durante o uso de videogames eram percebidas pelos usuários de games. Dessa maneira, eles descobriram o quanto os jogadores estavam engajados durante o uso do Xbox.

Os métodos mais modernos para a realização das pesquisas em neuromarketing são muitos, mas o EEG é o mais comum deles. Contudo ao contrário de EEG, o método fMRI, apresenta seus resultados em imagens e o EEG utiliza gráficos para mostrar seus resultados. Embora um pouco menos preciso, o EEG é mais barato e menos desconfortável, o que o torna a ferramenta mais utilizada em pesquisas de neuromarketing (RIBEIRO, 2009).

\section{Figura 2 Demonstração de equipamento de ressonância magnética com paciente.}

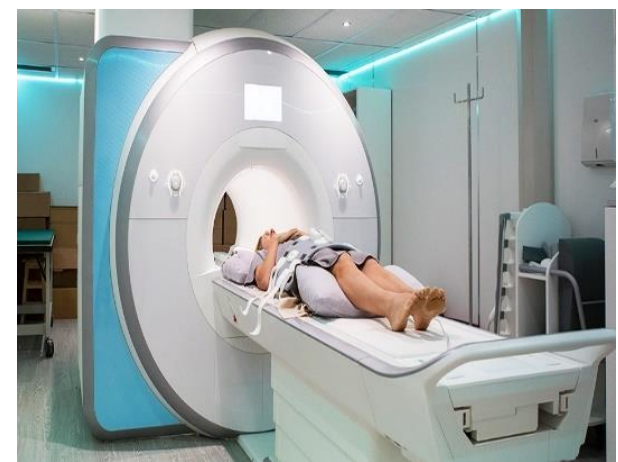

Fonte: https://ecomax-cdi.com.br/blog/ressonancia-magnetica-commenos-ruido/ 
A ressonância magnética produz imagens coloridas da troca de substâncias no cérebro e registros instantâneos da localização e intensidade da atividade cerebral. Os sinais de radiofrequência da fMRI fornecem a imagem das alterações no fluxo sanguíneo e a oxigenação em determinadas áreas cerebrais. Por isso esse método pode mostrar como a intensidade cerebral de uma pessoa pode se alterar diante de anúncios publicitários (MUSSARA, 2016).

\subsection{As tendências atuais para pesquisas em neuromarketing}

Segundo Tellini (2017), no contexto atual existem algumas tendências para a realização de pesquisas em neuromarketing, são elas: a) Integração de ferramentas de neuromarketing para avaliação de comunicação; b) metrificação da resposta emocional gerada por produtos e embalagens; c) avaliação de espaços publicitários; d) neuromarketing digital.

A integração de ferramentas de Neuromarketing para avaliar a comunicação é importante, ganha destaque devido a necessidade de se obter métricas que integrem análise complementares, principalmente quando levamos em consideração a interminável discussão sobre campanhas emocionais versus campanhas com CTA (Call To Action) que significam em inglês, "chamada para uma ação" (TELLINI, 2017).

Você ainda pode estar se perguntando, o que são as CTA? como elas funcionam e qual a sua relação com o neuromarketing? 
As CTA são aquelas campanhas que geralmente utilizam em seu formato um botão, que é criado para levar o usuário a realizar uma ação em seu e-mail marketing, newsletter ou site. Essas campanhas são imprescindíveis para incorporar as análises detalhadas, a influência da campanha no comportamento do consumidor, reforço do posicionamento da marca, impacto sobre a intenção de compra dos produtos e serviços anunciados. Trata-se de uma ótima maneira para realizar este tipo de avaliação integrada que se mostra como uma alternativa muito escolhida pelas empresas, pois a mesma trata-se da associação de diferentes técnicas de neuromarketing. Essa associação ocorre entre as técnicas neurométricas (eletroencefalograma-EEG) e as metodologias comportamentais, que são o teste implícito de associação (TIA) e o eyetracking (TELLINI, 2017).

\section{Figura 3 Eyetracking a técnica de rastreamento ocular}

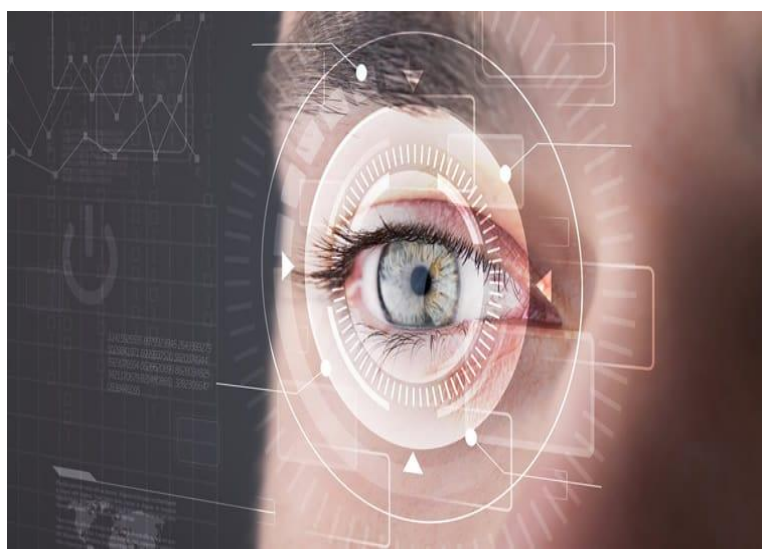

Fonte: https://usabilitygeek.com/what-is-eye-tracking-when-to-use-it/ 
De acordo com Hansen e Qiang (2010), o eyetracking é uma técnica que procede ao rastreamento ocular, permitindo medir a posição e o comportamento do movimento ocular. É uma técnica comum em pesquisas sobre o sistema visual, psicologia, linguística e, nos últimos anos o seu raio de aplicação estendeu-se ao comportamento do consumidor nas pesquisas de neuromarketing. $\mathrm{O}$ eyetracking pode possibilitar aos profissionais de marketing um melhor entendimento quanto as informações e os aspectos visuais para os quais os consumidores direcionam o seu olhar. Nesse teste algumas variáveis são mensuradas no consumidor, tais como: a fixação visual; o movimento ocular; a dilatação pupilar; a excitação emocional e o foco atencional. A partir dessas mensurações é possível testar websites e a eficácia do respetivo layout, interface e da experiência de navegação; analisar os comportamentos do consumidor em ambiente de loja (testar colocação de produtos, materiais gráficos das prateleiras, disposição no linear, entre outros); testar publicidades em vídeo e campanhas impressas; determinar a hierarquia de percepção visual (que elementos captam a atenção em primeiro lugar do consumidor, entre outros aspectos).

\section{E o teste implícito de associação (TIA) mostra o quê? Como podemos defini-lo?}

Enquanto o EEG e o eye-tracking identificam os elementos mais eficientes para chamar a atenção, gerar maiores índices de memorização e provocar emoções mais intensas no consumidor, o TIA mostram como uma campanha influencia as associações inconscientes entre 
marcas/produtos e determinados conceitos. Sendo assim, através da integração de ferramentas de neuromarketing, é possível uma melhor compreensão sobre todos os pontos relacionados à atenção, motivação e memorização, como também possibilita avaliar se uma campanha reforça o posicionamento de uma marca e se aumenta a intenção de compra de certos produtos (TELLINI, 2017).

Então, se as tendências para a realização de pesquisas no objeto de estudo da nossa temática, estão ligadas a integração de diversas ferramentas de neuromarketing para avaliação de comunicação. Como a metrificação da resposta emocional gerada por produtos e embalagens funciona?

De acordo com Tellini (2017) a metrificação da resposta emocional gerada por produtos e embalagens é bastante utilizada pelas empresas, porque atualmente muito se fala sobre comoditização, guerra de preços, aumento de competitividade e crise, mas pouco se discute sobre formas eficientes de contornar todas essas questões. Diante do cenário atual, a fidelidade às marcas está cada vez menor, e o comportamento do consumidor está mudando. Nesse contexto, o neuromarketing pode ajudar a metrificar a experiência do consumidor e a desenvolver produtos mais atraentes e que vendem mais. Isso é feito pelos estudiosos na área, pois algumas ferramentas são capazes de avaliar as seguintes questões:

\footnotetext{
$\checkmark$ Como o seu produto é percebido pelos consumidores;
} 
$\checkmark \quad$ Se o posicionamento do produto está de acordo com o da categoria;

$\checkmark \quad$ Se o produto chama atenção;

$\checkmark \quad$ Qual é o valor percebido pelo consumidor;

$\checkmark \quad$ Qual é a resposta emocional gerada pelo produto e por sua embalagem.

\section{Mas e quanto a questão do neuromarketing na avaliação de espaços publicitários? Como essa nova tendência ocorre?}

Tellini (2017) relata que apesar das opiniões acerca de métricas para avaliar espaços publicitários serem significativamente contrastantes, a avaliação de espaços publicitários representa um grande desafio para os profissionais que precisam comprovar a eficácia de seu trabalho, como também para os próprios veículos de comunicação. Além de orientar o desenvolvimento de campanhas e produtos, as ferramentas de neuromarketing também estão sendo muito procuradas por quem precisa de avaliações mais precisas de espaços publicitários. As métricas como porcentagem de visualização, engajamento, saliência, dentre outras, estão trazendo resultados bastante detalhados sobre os melhores formatos e posições de anúncios e sobre o seu impacto no comportamento do consumidor. Por exemplo, metodologias como a avaliação da sudorese do consumidor são capazes de revelar o nível de envolvimento do mesmo com o anúncio avaliado e como a sua visualização, influenciando dois pontos importantes que são a criação de marca e a intenção de compra. 
E a tendência das pesquisas no neuromarketing digital? O que é mais importante saber nesse tipo de pesquisa? Quais são as suas ferramentas?

As pesquisas digitais são práticas, rápidas e mais baratas que as realizadas presencialmente, elas são realizadas totalmente online e podem ajudar aos estudiosos a entenderem melhor o consumidor de forma mais rápida, mais prática, mais acessível e sem qualquer barreira geográfica (TELLINI, 2017).

O Portal Paraná (O QUE..., 2018), em seu portal descreve sobre o marketing digital e como o mesmo pode se apropriar do neuromarketing. Segundo as informações do portal existem três pontos principais que são: Inbound marketing, Storytelling e a Psicologia das cores.

\section{Mas o que são as ferramentas: o Inboud Marketing, o Storytelling e a psicologia das cores? Como essas ferramentas funcionam no marketing digital?}

O inbound marketing é uma ferramenta utilizada para captar novos clientes com uso de conteúdos relevantes, a mesma utiliza palavras certas para atrair a atenção necessária, fazendo com que o cérebro do cliente não se distraia com algo que possa ser mais interessante de ler.

Já o storytelling é uma ferramenta que aguça os sentidos e as emoções de uma forma mais simples e cativante, através de histórias. É uma estratégia que deve ser associada a marca ou produto e, por isso, mostrar os valores em um storytelling pode auxiliar ao cliente a se decidir. O poder de venda dessa ferramenta pode ser mais efetivo, pois algumas vezes o cliente se emociona com uma 
história associada à marca ou produto. Enquanto a psicologia das cores é uma ferramenta essencial para chamar a atenção do consumidor e pode ser combinada a uma imagem. Quando isso ocorre de forma correta a mesma pode impulsionar grandes resultados, um bom exemplo é a Black Friday (O QUE..., 2018).

Figura 4 Storytelling e seus elementos essenciais

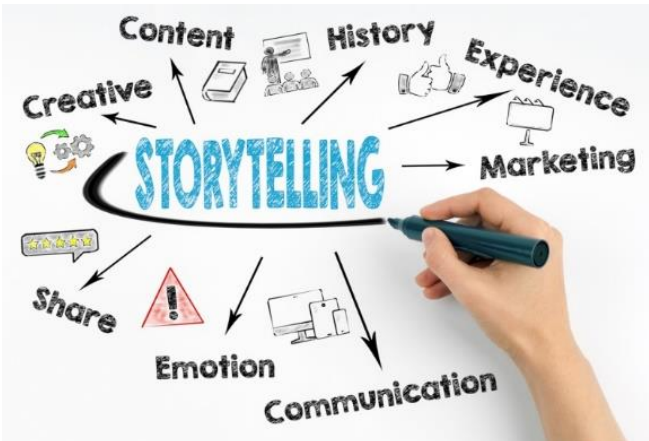

Fonte: https://fia.com.br/blog/storytelling/

Desse modo o presente conteúdo aborda o que é mais importante e inovador em termos de pesquisas na área de neuromarketing. As ferramentas de pesquisa em neuromarketing citadas ao longo desse conteúdo demonstraram que quando as mesmas são bem empregadas estas potencializam bons resultados de vendas no mercado consumidor, uma vez que as mesmas possibilitam o conhecimento dos desejos e das necessidades dos clientes.

\section{O que vimos neste conteúdo?}


- As pesquisar utilizando os preceitos do neuromarketing possibilitam as organizações empresariais a identificarem quais são os fatores determinantes nas tomadas de decisões de consumo;

- A maior parte das pesquisas em neuromarketing utilizam a fMRI (Imagem por Ressonância Magnética Funcional) ou o EEG (Eletroencefalografia) como métodos de pesquisa;

- $\quad$ As tendências atuais para a realização de pesquisas em neuromarketing, são: a integração de ferramentas de neuromarketing para avaliação de comunicação, a metrificação da resposta emocional gerada por produtos e embalagens, a avaliação de espaços publicitários e o neuromarketing digital;

- $\quad$ Os três pontos principais do marketing digital são: inbound marketing, storytelling e psicologia das cores.

\section{Leitura complementar}

LAS CASAS, A. L. Administração de marketing: conceitos, planejamento e aplicações à realidade brasileira. São Paulo: Atlas, 2013.

LINDSTROM, M. BrandSense: segredos sensoriais por trás das coisas que compramos. 2. ed. Porto Alegre: Bookman, 2012.

\section{REFERÊNCIAS}


ARIELY, D.; BERNS, G. Neuromarketing: the hope and hype of neuroimaging in business. Nature Reviews

Neuroscience, v. 11, n. 4, p. 284-292, 2010.

DIAS, A. M. Das "Neurociências Aplicadas ao

Marketing" ao "Neuromarketing Integrativo". Ciências \& Cognição, Rio de Janeiro, v. 17, n. 1, p. 178-189, abr. 2012. Disponível em:

http://pepsic.bvsalud.org/scielo.php?script=sci_arttext\&pi $\mathrm{d}=\mathrm{S} 1806-58212012000100014 \& \operatorname{lng}=\mathrm{pt} \& \mathrm{nrm}=\mathrm{iso}$. Acesso em: 8 jul. 2018.

HANSEN, D. W.; QIANG, J. The Eye of the Beholder: A Survey of Models for Eyes and Gaze, IEEE Transactions on Software Engineering, v. 32, n. 3, p. 478-500, 2010. Disponível em:

file://C:/Users/user/Downloads/WitznerJiPami2010.pdf. Acesso em: 9 jul. 2018.

LINDSTROM, M. A lógica do consumo: Verdades e mentiras sobre por que compramos. Tradução de Marcello Lino. Rio de Janeiro: Nova Fronteira, 2009.

MORIN, C. Neuromarketing: the new science of consumer behavior. Society, v. 48, n. 2, p. 131-135, 2011. Disponível em: http://fac.ksu.edu.sa/sites/default/files/Neuromarketing_1. pdf. Acesso em: 8 jul. 2018.

MUSSARA, F. Como lucrar com os nossos desejos neuromarketing. Oásis, ed. 121, 2016. Disponível em: 
file:///C:/Users/ML/Downloads/OASIS121.pdf. Acesso em: 9 jul. 2018.

NIELSEN Consumer Neuroscience Inaugura Laboratório de Neurociência para o Consumo em São Paulo. Nielsen, 03 nov. 2014. Disponível em:

http://www.nielsen.com/br/pt/press-room/2014/NielsenConsumer-Neuroscience-inaugura-laboratorio-deneurociencia-para-o-consumo-em-SP.html. Acesso em: 8 jul. 2018.

O QUE é neuromarketing e como aplicar no marketing digital? Paraná Portal, 29 mar. 2018. Disponível em: https://paranaportal.uol.com.br/colunas/tecnologia-einovacao/o-que-e-neuromarketing-e-como-aplicar-nomarketing-digital/. Acesso em: 9 jul. 2018.

RIBEIRO, S. Como são feitas as pesquisas de neuromarketing. Pequeno Guru, 2009. Disponível em: http://www.pequenoguru.com.br/2011/03/como-saofeitas-as-pesquisas-de-neuromarketing/. Acesso em: 08 jul. 2018.

TELLINI, G. As 4 tendências de Neuromarketing para 2017. Forebrain, 26 jan. 2017. Disponível em:

http://www.forebrain.com.br/noticias/as-4-tendencias-deneuromarketing-para-2017/. Acesso em: 9 jul. 2018. 


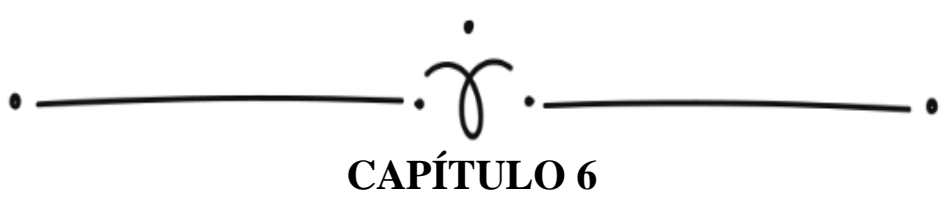

\title{
NEUROECONOMIA, ECONOMIA E FINANÇAS COMPORTAMENTAIS
}

\author{
Maria Goretti Fernandes \\ Izabela Souza da Silva \\ Égon José Mateus Celestino \\ Ivana Soares Barros
}

\section{INTRODUÇÃO}

No conteúdo a seguir, você irá estudar a respeito da neuroeconomia e da psicologia cognitiva. A influência da psicologia cognitiva nas tomadas de decisão de consumo e consequentemente nas finanças. Iremos discutir sobre economia e sua correlação com as finanças comportamentais, como questões subjetivas relacionadas aos impulsos sensoriais interferem na tomada de decisões na hora de consumir.

Iremos discutir como alguns estudos realizados correlacionam a neuroeconomia com o neuromarketing e como essa correlação será importante para a disciplina de neuromarketing. O presente conteúdo pretende demonstrar a relação entre as representações mentais, conhecimento e economia. Nesse contexto, abordaremos a influência dos modelos mentais nas tomadas de decisões na vida pessoal e organizacional. 


\subsection{A psicologia cognitiva e a neuroeconomia}

A psicologia cognitiva se refere a todos os processos pelos quais os impulsos sensoriais são transformados, reduzidos, elaborados, armazenados, recuperados e usados. A psicologia cognitiva, bem como a neurociência trazem evoluções para a economia, no que se refere à tomada de decisão. As escolhas para a tomada de decisão para consumir são feitas por pessoas, desta forma, as subjetividades não podem ser desconsideradas. Sendo assim, a abordagem da psicologia cognitiva considera que o processo de tomada de decisão é algo interativo, pois, vários aspectos como percepções, convicções pessoais, modelos mentais, entre outros, podem influenciar e interferir na tomada de decisão (TVEDE, 2000).

\section{Você já deve ter se perguntado: Por que os anúncios ou propagandas para vender produtos às mulheres são diferentes dos anúncios para os homens?}

Porque, de acordo com Madan (2010), o cérebro é fisiologicamente afetado por propagandas e estratégias de marketing. A neurociência vem contribuindo para o esclarecimento do nosso entendimento da relação entre a mente e a ação. A mente possui processos automáticos do comportamento que ocorrem com pouca ou nenhuma percepção. Outro fator importante que esta ciência apresenta é que o sistema cognitivo interfere no sistema deliberativo, sendo então o comportamento de tomada de decisão um resultado da interação entre o sistema automático com processos controlados e os sistemas 
cognitivos e afetivos (LOWENSTEIN; CAMERER; PRELEC, 2008).

\section{Mas será que imagens mentais influenciam na hora de tomar decisões?}

Sim, as imagens mentais influenciam na hora de tomar uma decisão como comprar, por exemplo. Os métodos da neurociência com o objetivo de observar, mapear e mensurar as "imagens do cérebro" no desempenho de uma tarefa, indicaram que existem diferenças entre o funcionamento comportamental e cognitivo, isto porque as imagens mentais (ilusões ou representações mentais) influenciam na escolha do sujeito.

Kahneman e RIEPE (1998) fazem referência à neuroeconomia, uma ilusão cognitiva é a tendência de cometer erro sistemático no processo de tomada de decisão dos humanos. Tais ilusões ocorrem, na visão desses autores, porque os humanos têm dificuldades para julgar subjetivamente quantidades físicas e probabilidades.

As ilusões cognitivas são geralmente classificadas em dois grupos: as ilusões resultantes da utilização de regras heurísticas nos processos de tomada de decisão e as ilusões causadas pela adoção de estruturais mentais descritas na teoria do prospecto da economia (TVERSKY; KAHNEMAN, 1974; KAHNEMAN; SLOVIC; TVERSKY, 1982).

Em seus primórdios, a economia criou técnicas matemáticas para predições econômicas que independessem da subjetividade humana, mas essa escolha levaria em consideração apenas axiomas matemáticos que 
trariam maior lucro ou menor perda financeira (MACEDO, 2003).

Caro leitor, você pode estar se perguntando agora o que são os axiomas? Como esse conceito é definido?

Os axiomas são verdades inquestionáveis, universalmente válidas, muitas vezes utilizadas como princípios na construção de uma teoria ou como base para uma argumentação. Dessa forma, a teoria econômica tradicional não leva em conta a subjetividade humana. Essa teoria encontra dificuldades em evidenciar que as escolhas são feitas por pessoas, e a tomada de decisão dessas, não segue um modo sistemático de previsão (MACEDO, 2003).

\subsection{Finanças comportamentais e sua correlação na neuroeconomia}

As finanças comportamentais também são definidas como sendo o estudo sobre como os seres humanos interpretam e agem com a informação para tomar decisões de investimentos. As finanças comportamentais são um campo relativamente novo na economia que está em evidência entre os investidores profissionais e, pode ser caracterizado como: uma integração da economia clássica e finanças com a psicologia e a ciência de tomada de decisão; uma tentativa de explicar o que causa algumas anomalias que são observadas na literatura de finanças (THALER, 1985).

Será que muitas vezes uma pessoa decide investir utilizando sua intuição? 
Sim. A tomada de decisões financeiras caracterizase, pela sua alta complexidade e incerteza. Tal contexto faz com que o investidor, muitas vezes, priorize sua intuição em detrimento da racionalidade postulada pelas modernas teorias de finanças, as quais estão baseadas em premissas de que o investidor é racional, avesso ao risco e que utiliza a curva de utilidade para maximizar seu bem-estar. Entretanto, esse julgamento intuitivo valorizado pelo investidor pode ser desencadeado por uma série de ilusões cognitivas e vieses cognitivos, que afetam as decisões de investimento, ocasionando tomadas de decisões equivocadas, não baseadas na racionalidade (SHARPE, 1991).

As pessoas confiam em princípios heurísticos que são processos cognitivos empregados em decisões não racionais. Esses princípios reduzem a complexa tarefa de acessar as probabilidades e predizer valores em operações de julgamento. Embora, esses processos cognitivos sejam úteis, algumas vezes, levam os indivíduos a cometerem sistemáticos e severos erros. Tais como, o investidor pode correr mais risco do que está previsto, sofrendo consequências que ele não poderia antecipar, estando mais propenso a realizar negociações injustificadas e culpando os outros ou a si mesmo pelos resultados ruins alcançados. Contudo, o reconhecimento desse efeito psicológico, bem como a identificação das situações particulares em que ele pode se manifestar, poderá ajudar os investidores a evitar erros melhorando assim a sua performance (TVERSKY, KAHNEMAN,1974). 


\subsection{Modelos mentais e sua influência na economia}

Os modelos mentais são imagens, pressupostos e histórias que trazemos em nossas mentes, acerca de nós mesmos, sobre outras pessoas, sobre instituições e sobre vários aspectos do mundo. São os nossos modelos mentais que influenciam as nossas tomadas de decisões e determinam a nossa forma de agir. Nesse capítulo iremos discutir como esses modelos mentais podem interferir nas decisões econômicas.

Imagens, assim como palavras, são símbolos proeminentes de nossa vida mental. No pensamento pósmodernista e relativista, considera-se que as imagens moldam nossa visão de realidade, ou ainda, que são a própria realidade; já os modelos mentais são como uma vidraça que emoldura e distorce sutilmente nossa visão e determinam o que vemos. Diferenças entre modelos mentais explicam porque duas pessoas podem observar o mesmo acontecimento e descrevê-lo de modo diferente; elas estão prestando atenção a detalhes diferentes (YORAM; CROOK; GUNTHER, 2006)

Por isso, os modelos mentais geralmente são tácitos, existindo abaixo do nível de consciência. Muitas vezes, eles não são testados nem examinados. Um bom exemplo, é que em algumas organizações produtivas, existe uma cultura imbricada de má qualidade dos serviços causada por preguiça ou sabotagem dos trabalhadores, sendo que esta ideia perdura mesmo entre gerentes que abraçam os princípios do movimento da qualidade. Ou seja, há uma representação social dominante neste quadro, onde mesmo 
que não seja realmente assim que as coisas acontecem, já há um preconceito de como elas são (CARBONE et al., 2006).

Outra dúvida pode vir a surgir após essa discussão. E por que acontece isso? Todos nós temos modelos mentais?

Sim, todas as pessoas possuem modelos mentais e estes são as representações internas do mundo externo para o sujeito e quando trabalhamos com o pensamento sistêmico, por muitas vezes, outras ideias confrontam diretamente nossos modelos mentais. A menos que nos seja permitido testar nosso ponto de vista, tendemos a reagir dizendo que a ideia é interessante, mas não pertinente ao caso, sem considerar de forma mais profunda as implicações da mesma (YORAM; CROOK; GUNTHER, 2006).

Então, como os modelos mentais podem interferir na economia?

Os modelos mentais podem parecer abstratos, mas não podem ser deixados de lado como meras ilusões de ótica, pois estes determinam a qualidade e o rumo das nossas vidas, e principalmente na economia, estes influenciam nas escolhas que podem gerar implicações de lucros e perdas (YORAM; CROOK; GUNTHER, 2006).

\subsection{Estudos entre a neuroeconomia e neuromarketing}


Nesse conteúdo, iremos abordar alguns estudos que foram realizados sobre a neuroeconomia e o neuromarketing. Esses apresentam como propósito da investigação científica sobre decisões financeiras que dependem dos processos cerebrais e emocionais.

Alguns estudos da neuroeconomia vem apontando que as decisões racionais dependem de um cuidadoso processamento emocional prévio (BECHARA, DAMASIO, 2005).

Os avanços destes estudos têm permitido mensurar diretamente pensamentos e emoções afirmando que muitas de nossas decisões são influenciadas pelas emoções sendo que tal influência ocorre desde as primeiras percepções acerca do contexto até a tomada de decisão (CAMERER; LOEWENSTEIN; PRELEC, 2005; PHELPS; LEDOUX 2005).

Por que será que as empresas utilizam tecnologias relacionadas à medicina diagnóstico por imagem, como por exemplo a ressonância magnética funcional, em suas pesquisas?

Porque através de estudos utilizando as técnicas de ressonância magnética, tais como: functional Magnetic Resonance Imaging (fMRI), descobriu-se que algumas estruturas cerebrais, como a amígdala, estavam diretamente associadas com o processamento de informações emocionais (PHELPS; LEDOUX 2005; LABAR; CABEZA, 2006; KENSINGER, 2007). Desse modo, as empresas podem aplicar os métodos neurocientíficos para analisar e entender o comportamento humano em sua 
relação com mercado e o marketing, possibilitando assim sucesso no comércio de seus produtos e marcas.

A amígdala que é uma pequena estrutura em forma de amêndoa, localizada na região antero-inferior do lobo temporal do cérebro, faz conexão com hipocampo e tem importante desempenho no controle das emoções de ordem maior como amizade, amor e afeição, nas exteriorizações do medo, da ira da agressividade, além de ser fundamental na autopreservação, por ser o centro identificador do perigo (MACHADO; HAERTEL, 2013)

Sabe-se que, além da amígdala, algumas outras áreas cerebrais também são acionadas durante os processos emocionais, são o núcleo accumbens e o córtex insular. Respectivamente, possuem papel de expressar e processar as emoções e avaliar as propostas arriscadas que interferem no sentido emocional do indivíduo (KIROUAC; GANGULY, 1995; NAQVI; SHIV; BECHARA, 2006). Dessa maneira, é fundamental para as grandes marcas entenderem como funciona o cérebro de seus clientes, pois essa compreensão seria a chave para fidelização.

\section{Você acha que estudando o cérebro humano e suas conexões as empresas poderiam vender mais?}

Sim, pois ao estudar a localização das áreas estimuladas no cérebro humano e as respostas deste a uma comunicação estaria se descobrindo a chave para o sucesso do consumo. Assim, para que as emoções entrassem de vez nesta análise do neuromarketing, diversos autores sinalizaram a existência no cérebro de um sistema múltiplo de tomada de decisões baseadas em modelos de 
processamento dual de informações (KAHNEMAN, SLOVIC, TVERSKY, 1982; SANFEY, 2007).

\section{Mas, você ainda poderia ficar confuso e questionar: será que esse processamento de tomadas de decisões ocorreria somente utilizando a razão?}

Não, pois esse processamento ocorre, tanto no âmbito da razão e da emoção. Uma vez que o cérebro seria composto de dois sistemas de tomada de decisão. Um, o deliberativo ou cognitivo, onde a tomada de decisão ocorreria de forma racional; o segundo seria o afetivo ou intuitivo, onde algumas decisões são tomadas levando em conta nosso estado emocional a intuição e nossas experiências (DAMASIO, 1995; BECHARA; DAMASIO, 2005).

Arkes (2003) afirma que as emoções possuem pelo menos dois principais papéis no processo de tomada de decisão e enfatiza que o próprio humor do indivíduo no momento da tomada de decisão pode afetar as escolhas de uma pessoa. Segundo o autor, quando as pessoas estão de mau humor, elas tendem a ser mais sensíveis a eventos negativos. Por outro lado, quando estão de bom humor, se lembram mais de eventos positivos e ficam mais otimistas com relação ao futuro.

Dessa forma, podemos concluir que a neuroeconomia, a economia e as finanças comportamentais desempenham um importante papel no estudo do neuromarketing, pois ficou claro com base nos estudos e evidências científicas que apresentamos nessa temática. É importante compreender que muitas tomadas de decisões 
envolvendo investimentos financeiros são realizadas pelas pessoas impulsivamente. Ficando claro que questões subjetivas como, modelos mentais e emoções, podem interferir no mercado econômico do ponto de vista pessoal e organizacional.

\section{O que vimos neste conteúdo?}

- Ao desvendar as reações neurológicas das pessoas durante o consumo e descobrir o comportamento delas, as organizações poderão utilizar isso de forma eficaz em suas estratégias de vendas, sendo o segredo de muitas marcas famosas que estão há anos no mercado consumidor.

- $\quad$ A disciplina de neuromarketing deve ser estudada por vários profissionais e ensinada em diversos cursos, pois ela sugere caminhos e estratégicas organizacionais baseadas em evidências científicas.

- $\quad$ As emoções possuem pelo menos dois principais papéis no processo de tomada de decisão e enfatiza que o próprio humor do indivíduo no momento da tomada de decisão pode afetar as escolhas de uma pessoa.

- As questões subjetivas como, modelos mentais e emoções, podem interferir no mercado econômico do ponto de vista pessoal e organizacional.

\section{Leitura complementar}


CAMARGO, P. C. J. de. Neuromarketing: a nova pesquisa de comportamento do consumidor. São Paulo: Atlas, 2013.

CHAVAGLIA NETO, J. Neuromarketing: o efeito de ancoragem, do contexto e o papel dos eurotransmissores na mente dos consumidores. São Paulo: Baraúna, 2012.

Sugerimos a leitura dos primeiros capítulos das referências bibliográficas citadas acima, para que você se familiarize com as ideias centrais do neuromarketing e reflita sobre o capítulo que você acabou de estudar.

\section{REFERÊNCIAS}

ARKES, H. R. The Psychology of patient decision making. In: MAX, M. B.; LYNN, J. (ed.). Symptom Research: methods and opportunities. Baltimore: National Institutes of Health/National Institutes of Dental and Craniofacial Research, 2003. p. 2-21.

BECHARA, A.; DAMASIO, A. R. The somatic marker hypothesis and decision-making. Games and Economic Behavior, v. 52, n. 2, p. 336-372, 2005.

CAMERER, C.; LOEWENSTEIN, G.; PRELEC, D.

Neuroeconomics: How neuroscience can inform economics. Journal of Economic Literature, v. 43, n. 1, p. 9-64, mar. 2005. 
CARBONE, P. P. et al. Gestão por competências e gestão do conhecimento. 2. ed. Rio de Janeiro: FGV, 2006.

DAMASIO, A. R. Toward a neurobiology of emotion and feeling: operational concepts and hypotheses.

Neuroscience, v. 1, n. 1,p. 9-25, 1995.

PHELPS, E. A.; LEDOUX, J. E. Contributions of the amygdala to emotion processing: From animal models to human behavior. Neuron, v. 48, n. 2, p. 175-187, 2005.

KAHNEMAN, D.; RIEPE, M. W. Aspects of investor psychology - Beliefs, preferences, and biases investment advisors should know about. Journal of Portfolio Management, v. 24, n. 4, p. 52-65, 1998.

KAHNEMAN, D.; SLOVIC, P.; TVERSKY, A. Judgment under uncertainty: Heuristics and biases. Cambridge: Cambridge University Press, 1982.

KENSINGER, E. A. Negative Emotion Enhances Memory Accuracy: Behavioral and Neuroimaging. Evidence Current Directions in Psychological Science, v. 16, n. 4, p. 213-218, 2007.

KIROUAC, G. J.; GANGULY, P. K. Topographical organization in the nucleus accumbens of afferents from the basolateral amygdala and efferents to the lateral hypothalamus. Neuroscience, v. 67, n. 3, p. 625-630, 1995. 
LABAR, K. S.; CABEZA, R. Cognitive neuroscience of emotional memory. Nature Reviews Neuroscience, v. 7 , p. 54-64, 2006.

LOWENSTEIN, G.; CAMERER, C.; PRELEC, D. A aurora da neuroeconomia. HSM Management, Barueri, ed. 67, p. 72-76, mar./abr. 2008.

MACEDO JR., J. S. Teoria do prospecto: uma investigação utilizando simulação de investimentos. 2003. 203 f. Tese (Doutorado em Engenharia de Produção) Universidade Federal de Santa Catarina, Florianópolis, 2003.

MACHADO, A. B. M.; HAERTEL, L. M.

Neuroanatomia funcional. 3. ed. São Paulo: Atheneu, 2013.

MADAN, C. R. Neuromarketing: the next step in market research? Eureka, v. 1, n. 1,

p. 34-42, mar. 2010.

NAQVI, N.; SHIV, B.; BECHARA, A. The role of emotion in decision making: A Cognitive Neuroscience Perspective. Current Directions in Psychological Science, v. 5, n. 15, p. 260-264, 2006.

SANFEY, A. G. Decision Neuroscience: new directions in studies of judgment and decision making. Current Directions In Psychological Science, v. 16, n. 3, p. 151155, 2007. 
SHARPE, W. F. Capital Asset Prices with and without Neative Holding. The Journal of Finance, v. 46, n. 2, p. 489-509, 1991.

THALER, R. Mental accounting and consumer choice. In: THALER, R. Quasi Rational Economics. New York: Russel Sage Foundation, 1985. p. 25-48.

TVEDE, L. The Psychology of Finance. Hoboken, NJ: John Willey and Sons, 2000.

TVERSKY, A.; KAHNEMAN, D. Judgment under uncertainty: heuristics and biases. Science, v. 185, issue 4157, p. 1124-1131, sep. 1974.

YORAM, J. W.; CROOK, C.; GUNTHER, R. A força dos modelos mentais: Transforme o negócio da sua vida e a vida do seu negócio. Porto Alegre: Artmed, 2006. 


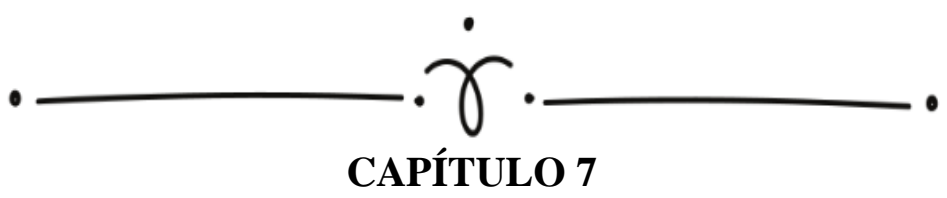

\title{
A NEUROCIÊNCIA E A PESQUISA DE COMPORTAMENTO ECONÔMICO
}

\author{
Izabela Souza da Silva \\ Maria Goretti Fernandes \\ Égon José Mateus Celestino \\ Ivana Soares Barros
}

\section{INTRODUÇÃO}

No tema anterior, discutimos as questões referentes a economia, a neuroeconomia $e$ as finanças comportamentais, mas nesse capítulo iremos relatar como a neurociência interfere também na pesquisa de comportamento econômico. Além disso, iremos tratar das questões relacionadas à gestão do conhecimento e a sua importância nas organizações, a economia do conhecimento, os mecanismos cerebrais e a sua influência na economia, e a correlação da neuroeconomia nas finanças. Esses conhecimentos serão de extrema importância para um melhor desempenho dos profissionais envolvidos em decisões de caráter econômico que exigem conhecimento prévio de neuroeconomia.

7.1 - A gestão do conhecimento e sua importância nas organizações 
É importante destacar que a neurociência e a psicologia cognitiva vem contribuindo e proporcionando grandes evoluções para a economia, principalmente ao que ser refere à tomada de decisão. As escolhas para a tomada de decisão são feitas por pessoas, desta forma, questões como as subjetividades não podem ser desconsideradas. Entende-se por psicologia cognitiva como sendo aquela abordagem que se refere a todos os processos pelos quais os impulsos sensoriais são transformados, reduzidos, elaborados, armazenados, recuperados e usados. A psicologia cognitiva considera que o processo de tomada de decisão é algo interativo, isto porque, vários aspectos como percepções, conviç̧ões pessoais, modelos mentais, entre outros, podem influenciar e interferir na tomada de decisão (TVEDE, 2000).

\section{Mas o que sabemos em relação à neurociência e com relação à tomada de decisão? Como esse processo acontece?}

A neurociência e seus os estudos do cérebro e do sistema nervoso vem contribuindo com o esclarecimento do nosso entendimento da relação entre a mente e a ação. A mente possui processos automáticos do comportamento que ocorrem com pouca ou nenhuma percepção. O sistema cognitivo interfere no sistema deliberativo, sendo então o comportamento de tomada de decisão um resultado da interação entre o sistema automático com processos controlados e os sistemas cognitivos e afetivos (LOWENSTEIN; CAMERER; PRELEC, 2008). 
Para Kahneman e Riepe (1998) os métodos utilizados pela neurociência com o objetivo de observar, mapear e mensurar as imagens do cérebro no desempenho de uma tarefa indicam que existem diferenças entre o funcionamento comportamental e o cognitivo, bem como que as imagens mentais (ilusões ou representações mentais) influenciam na escolha de uma pessoa. Ao se fazer referência à neuroeconomia, as ilusões ocorrem porque os humanos tem dificuldades para julgar subjetivamente quantidades físicas e probabilidades. Portanto, uma ilusão cognitiva é a tendência de cometer erro sistemático no processo de tomada de decisão dos humanos. É importante destacar que sempre o homem sentiu necessidade de compreender outros modelos do comportamento humano. As ciências sociais iniciaram esses estudos na década de 70, através do estudioso Paul Slovic's, que em 1972 iniciou o estudo sobre a percepção individual dos riscos. Já em 1974, Amos Tversky e Daniel Kahneman estudavam sobre as regras heurísticas e em 1979, iniciaram-se os estudos sobre as estruturas mentais (TVERSKY e KAHNEMAN, 1974; KAHNEMAN; TVERSKY, 1979).

\section{Você pode se questionar, após ler o texto acima, sobre como são as ilusões e como elas são classificadas?}

Não existe ainda um consenso para classificar as ilusões cognitivas, mas geralmente elas são classificadas em dois grupos: as ilusões resultantes da utilização de regras heurísticas nos processos de tomada de decisão e as ilusões causadas pela adoção de estruturais mentais 
descritas na teoria do prospecto da economia (TVERSKY; KAHNEMAN, 1974; KAHNEMAN; TVERSKY, 1979).

\section{Mas como seria possível prever a economia e suas escolhas? Como não ter prejuízo? Como abrir mão de uma escolha e decidir por outra?}

Em seus primórdios históricos, a economia criou técnicas matemáticas para predição econômica que independessem da subjetividade humana. A escolha consideraria apenas estudos matemáticos para proporcionarem maior lucro ou menor perda financeira. Porém, a Teoria Econômica Tradicional encontra dificuldades ao evidenciar que as escolhas são feitas por pessoas e a tomada de decisão dessas escolhas não segue um modo sistemático de previsão, mas o oposto, pois ao optar por uma escolha, o ser humano sabe que estará abrindo mão da outra. Isso parece bastante simples, porém tem implicações bem mais profundas, já que a pessoa, ao abrir mão de uma opção, sabe que estará desistindo de inúmeras futuras possibilidades que a não-escolha poderia oferecer-lhe (FERREIRA et al., 2008).

\section{Então, não é aconselhável tomar decisões econômicas} com base apenas em estudos e pesquisas matemáticas?

Exatamente, uma vez que qualquer pessoa não tomará decisões baseadas somente em estudos matemáticos, pois o comportamento das pessoas também é influenciado por sentimentos. Esses sentimentos são construtos incongruentes que consideram a generalização das respostas dos sujeitos a partir de uma balança entre 
custo e benefício. Ou seja, é necessário acrescentar a questão da subjetividade na forma que a economia tradicional se apresentava para a tomada de decisão, considerando que as escolhas são feitas por pessoas e como estas avaliam o problema (FERREIRA et al., 2008).

Os psicólogos Daniel Kahnemann e Amos Taversky, em 1979, desenvolveram a Teoria do Prospecto, a qual surgiu como uma alternativa para explicar as questões referentes à economia. Essa teoria considera que, ao escolher, a pessoa apresenta diferentes padrões de comportamento, pois considera que as pessoas avaliam prospectos arriscados com base em mudanças de riqueza relativas a algum ponto de referência. Segundo a referida teoria, o indivíduo é avesso ao risco para ganhos, mas é propenso ao risco para perdas, pois prefere a certeza de um ganho a qualquer prospecto de risco cujo ganho esperado seja maior (MACEDO JR, 2003).

Já o Efeito Disposição, conhecido como Disposition Effect, é baseado nos estudos realizados pela Teoria do Prospecto. É considerado um efeito psicológico relacionado com uma pré-disposição dos indivíduos em determinar o valor inicial (preço de compra) dos investimentos a partir de seu ponto de referência, com o objetivo de avaliar se a venda dos investimentos irá gerar ganhos ou perdas (SHREFRIN; STATMAN, 1985).

Desse modo, podemos nos questionar se a Teoria do Prospecto, considerando a subjetividade frente à tomada de decisão, trouxe algumas contribuições para a economia? 
Sim, Segundo Macedo JR (2003), algumas contribuições foram a constatação de que os investidores tem foco na alteração de riqueza frente a seu ponto de referência (ex.: nível de riqueza atual). Assim como, que os problemas de decisão ocorrem em 2 etapas: em primeiro, a escolha é relacionada com o ponto de referência; e, em segundo, os pontos são considerados como ganho quando excedem esse ponto de referência e são considerados como perda quando não o alcançam.

\section{2 - Economia e gestão do conhecimento nas organizações}

Atualmente, a economia recebe grande influência da gestão do conhecimento, principalmente nas grandes organizações. Essa estratégia é muito utilizada, pois o compartilhamento do conhecimento pode beneficiar qualquer organização. Sabe-se que mesmo em unidades de negócio altamente diversificadas, com clientes diferentes e propostas de valor sob medida, as organizações executam muitos processos semelhantes ou idênticos. Ao compartilhar informações sobre processos comuns, a organização tem mais oportunidades de identificar as melhores práticas que possam ser implementadas com rapidez em todas as unidades de negócio (KAPLAN; NORTON, 2006).

\section{Mas o que é gestão do conhecimento? Como podemos explicá-la?}

É correto afirmar que usamos pouco das informações sensoriais que recebemos do mundo externo, a 
maioria dessas informações é descartada. A maior parte do que vemos está em nossa mente e a capacidade de discernir é diferente da capacidade de ver. $\mathrm{O}$ conceito de gestão do conhecimento pode ganhar variadas interpretações. De maneira simples, pode-se dizer que são práticas de gestão organizacional voltadas para produção, retenção, disseminação, compartilhamento e aplicação do conhecimento dentro das organizações, bem como para promover o intercâmbio de experiências com o mundo externo (NONAKA; TAKEUCHI, 1997).

\section{A quem é atribuída a posição de gestor do conhecimento nas organizações?}

Em termos de compartilhamento de conhecimento, quanto maior e mais diversificada for a corporação, maior serão as probabilidades de inovação nos processos, em benefício de todas as unidades de negócio da corporação. Hoje, a tarefa de identificar e de transferir conhecimentos tem sido atribuída a uma nova posição organizacional: o diretor de conhecimento (KAPLAN; NORTON, 2006).

\subsection{Os mecanismos cerebrais e sua influência na neuroeconomia}

Para entender como a neuroeconomia é influenciada pelos mecanismos cerebrais, é importante entender sobre algumas teorias e sobre os sistemas emocionais. A teoria da economia tradicional que fala a respeito da maximização da utilidade restrita, relata que as decisões são tomadas com base em um modelo de deliberação, um balanceamento dos custos e benefícios entre diferentes opções. Sabe-se que a 
deliberação faz parte do processo decisório humano, a neurociência revela duas inadequações dessa abordagem, as quais estão relacionadas com os importantes papéis dos processos automáticos e dos processos controlados. Esses tipos de processamentos se desenvolveram para resolver problemas de importância evolucionária, não para respeitar as máximas lógicas e, por isso, não consideram custos e benefícios em dada decisão (LOWENSTEIN; CAMERER; PRELEC, 2008).

\section{Então, como ocorrem as más decisões? Como os sistemas estão interligados durante esse processo?}

O nosso comportamento é influenciado por sistemas emocionais que são essenciais para nosso funcionamento diário e, quando são lesionados ou perturbados, fazem com que a capacidade deliberativa simplesmente desmorone, resultando em más decisões no longo prazo. O comportamento humano emerge tanto da interação entre os sistemas controlados e automáticos como da relação dos sistemas cognitivos e afetivos. Os processos controlados, que podem ser cognitivos (racionais) ou afetivos, usam lógica ou cálculos passo a passo, tendem a ser invocados conscientemente pelo indivíduo quando ele encontra um desafio ou surpresa e com frequência são associados a uma sensação subjetiva de esforço. As pessoas, em geral, conseguem fazer um bom relato de seus processos controlados. Ferramentas-padrão de economia como as árvores de decisão e a programação dinâmica podem ser encaradas como representações estilizadas de processos 
controlados. (LOWENSTEIN; CAMERER; PRELEC, 2008).

Os processos automáticos podem ser cognitivos ou afetivos e constituem o modo-padrão de operação do cérebro. Eles estão em atividade o tempo todo, até mesmo enquanto sonhamos. Os processos controlados, por sua vez, ocorrem em momentos especiais em que os processos automáticos são interrompidos, o que acontece quando uma pessoa se vê diante de fatos inesperados; vivencia estados viscerais fortes ou se depara com algum tipo de desafio explícito e inusitado (FERREIRA et al., 2008).

\section{As decisões de uma pessoa impulsiva são excessivamente influenciadas por emoções, estímulos, pressões e exigências externas?}

Sim. Uma pessoa pode não conseguir dar uma explicação mais satisfatória para uma ação impulsiva, exceto que ela automaticamente achou que deveria agir assim. O afeto também pode distorcer as avaliações cognitivas. Por exemplo, as emoções influenciam nossas percepções quanto aos riscos: a ira torna as pessoas menos sensíveis aos riscos, assim como a tristeza. As emoções ainda podem criar uma cognição motivada, que é aquela na qual as pessoas são boas em persuadir a si mesmas, ou seja, o que elas gostariam que acontecesse é o que vai acontecer. Esse tipo de pensamento também pode explicar os altos índices de fracassos de novas empresas e de negociações no mercado financeiro, pouca poupança e baixas taxas de investimento em educação. Assim, a neurociência pode 
oferecer novas explicações para vários dos fenômenos estudados pela economia (FERREIRA et al., 2008).

\section{Você já ouviu falar sobre o modelo econômico canônico? Como o cérebro processa esse modelo?}

O modelo econômico canônico supõe que a utilidade do dinheiro seja indireta, isto é, que ele é um meio de troca, valorizado somente pelos produtos e serviços que consegue comprar. Assim, a economia-padrão encara o prazer de comer e o prazer de ganhar dinheiro como dois fenômenos totalmente diferentes. A ideia de que muitas recompensas são processadas de forma semelhante no cérebro acabam tendo implicações importantes para a economia, que supõe que a utilidade do dinheiro depende do que ele compra. Se ganhar dinheiro proporciona um prazer direto, a experiência de desfazer-se dele provavelmente é dolorosa. Tanto a colaboração como a competição entre afeto e cognição, e entre processos controlados e automáticos, podem ser encaradas no domínio da tomada de decisão sob risco e incerteza. O modelo econômico de utilidade esperada é aquele em que a tomada de decisão está sob incerteza como uma série de alternativas de utilidade em diferentes cenários. Segundo as teorias econômicas tradicionais, as pessoas tentam avaliar o nível objetivo de risco que os diferentes perigos podem apresentar (FERREIRA et al., 2008).

\section{E você acha que as reações emocionais e as percepções são levadas em consideração pela economia?}


Exatamente. As reações emocionais podem ajudar a explicar tanto a aversão ao risco como a atração por ele. Cerca de $1 \%$ das pessoas que jogam abusivamente são diagnosticadas como patológicas, elas relatam perder o controle e prejudicar seus relacionamentos pessoais por jogar. Em muitas áreas da economia, há conceitos básicos que podem ser considerados processos neurais e estudados com o uso de ferramentas da neurociência. Além disso, a percepção pessoal do risco envolvido em alternativas de investimento explica melhor a decisão tomada pelas pessoas do que o modelo racional, no qual o risco é medido pelo desvio-padrão. Isso demonstra que os tomadores de decisão percebem e valorizam alternativas de risco de maneira diferente uns dos outros e ainda que a forma com que percebem o risco é significativamente diferente da forma racional com que o risco é constantemente mensurado (FAMA, 1970).

\section{Por que os preços das ações variam? Por que as pessoas negociam? Por que há tantos fundos de investimentos ativos apesar do mau desempenho?}

Para responder a essas perguntas, basta saber que ainda não há uma teoria amplamente aceita. Porém, saber mais a respeito dos mecanismos neurais básicos por trás do medo, da ganância, do conformismo e do pensamento volitivo (aquele de que tudo sempre vai dar certo) talvez nos ajude a entender esses enigmas. As decisões com base em um modelo de deliberação promovem um balanceamento dos custos e benefícios entre diferentes opções, sendo essas as finanças comportamentais, que se 
configuram como uma ciência que engloba conceitos de finanças, e a psicologia cognitiva, que tem o objetivo de entender e predizer as implicações sistemáticas no mercado financeiro do processo psicológico de tomada de decisão (BRABAZON, 2000).

\section{4 - Neuroeconomia nas finanças comportamentais}

A neuroeconomia tem papel importante nas finanças comportamentais do ser humano. Isso porque o ambiente de tomada de decisões financeiras caracteriza-se, muitas vezes, pela sua alta complexidade e incerteza. Tal contexto faz com que o investidor, muitas vezes, priorize sua intuição em detrimento da racionalidade postulada pelas modernas teorias de finanças, as quais estão baseadas em premissas de que o investidor é racional, avesso ao risco e que utiliza a curva de utilidade para maximizar seu bem estar (MARKOWITZ, 1952; FAMA, 1970; SHARPE, 1991).

Contudo, esse julgamento intuitivo valorizado pelo investidor pode ser desencadeado por uma série de ilusões cognitivas, as heurísticas e vieses cognitivos, que afetam as decisões de investimento, ocasionando tomadas de decisões equivocadas, não baseadas na racionalidade (KAHNEMANN; RIEPI, 1998).

Segundo Tversky e Kahneman (1974), as pessoas confiam em um limitado número de princípios heurísticos, os quais reduzem a complexa tarefa de acessar as probabilidades e predizer valores em operações de julgamento. Embora essas heurísticas sejam úteis, algumas vezes, levam os indivíduos a cometerem sistemáticos e 
severos erros. Faz, por exemplo, com que o investidor corra mais risco do que previra, sofra consequências que não pode antecipar, esteja mais propenso a realizar negociações injustificadas e acabe culpando os outros ou a si mesmo pelos resultados ruins alcançados. Contudo, o reconhecimento desse efeito psicológico, bem como a identificação das situações particulares em que ele pode se manifestar, poderão ajudar os investidores a evitar erros geralmente provocados pelas heurísticas na alocação de ativos, melhorando, consequentemente, sua performance.

\section{Como as ilusões cognitivas exercem influência na tomada de decisões? Por que é importante fazer como que os investidores identifiquem as ilusões cognitivas?}

Ilusões cognitivas são como ilusões de ótica; apesar de fáceis de entender, são difíceis de eliminar. Para esses autores, o objetivo de apreender sobre ilusão cognitiva e sobre o processo de tomada de decisão é poder reconhecer as situações em que esse erro particular pode se manifestar para poder ajudar o investidor a evitar erros no processo de alocação de ativos e, por consequência, melhorar sua performance futura (KAHNEMAN; RIEPE, 1998).

O conhecimento por parte do investidor de como as ilusões cognitivas podem afetar o processo de decisão financeira é extremamente importante, pois permite evitar as consequências negativas das mesmas. Dessa forma, conhecer e fazer os investidores identificarem as ilusões cognitivas, as quais eles estão sujeitos, tem fundamental importância para a melhoria do processo de alocação de investimentos. (MACEDO JR, 2003) 
Thaler (1985) considera que os estudiosos de finanças estarão cometendo um erro se continuarem a supor que os investidores são sempre racionais. Na visão de Shiller (1999), os mais significativos estudos em finanças empíricas incorporam modelos de comportamento humano provenientes da psicologia, sociologia e antropologia.

Conforme discutimos anteriormente, as finanças modernas acreditam que os mercados financeiros são eficientes, pois o seu principal pressuposto é que os agentes econômicos agem racionalmente e obedecem a teoria da utilidade esperada. Racionalidade nesse contexto significa que os investidores utilizam todas as informações disponíveis de um modo lógico e sistemático para fazer escolhas ótimas, dadas as alternativas que dispõe e os objetivos a serem alcançados. Contudo, o pressuposto sobre a eficiência dos mercados tem uma longa história nas pesquisas realizadas sobre finanças. A hipótese foi estabelecida por Gibson em 1889. Entretanto, desde o início, sempre houve uma tensão sobre a hipótese, um sentimento de que havia alguma coisa de errado com ela. Posteriormente, os estudos realizados sobre as anomalias no mercado financeiro confirmaram realmente que os principais pressupostos do comportamento racional não estavam inteiramente corretos. (SHILLER, 2000)

\section{O que vimos nesse conteúdo?}

- A neurociência interfere na pesquisa de comportamento econômico. Dessa forma, a neurociência e a psicologia cognitiva vem contribuindo e proporcionando 
grandes evoluções para a economia, principalmente ao que ser refere à tomada de decisão.

- A economia recebe grande influência da gestão do conhecimento, em especial, nas grandes organizações. Essa estratégia é muito utilizada pelas empresas, pois o compartilhamento do conhecimento pode beneficiar qualquer organização.

- A neuroeconomia é influenciada pelos mecanismos cerebrais, sendo importante entender sobre algumas teorias e sobre os sistemas emocionais.

- A neuroeconomia tem papel importante nas finanças comportamentais do ser humano. Isso porque o ambiente de tomada de decisões financeiras caracteriza-se, muitas vezes, pela sua alta complexidade e incerteza.

\section{Leitura complementar}

LINDSTROM, M. Brand Sense: segredos sensoriais por trás das coisas que compramos. 2. ed. Porto Alegre: Bookman, 2012.

Você deve complementar os seus estudos lendo os capítulos iniciais da leitura acima e fazendo correlação com o que apresentamos nesse conteúdo.

LUDOVICO, N.; SANTINI, F. R. Gestão de marketing:

O plano de marketing como orientador das decisões. São Paulo: Saraiva, 2014. (Série gestão empresarial). 
Ao ler esse livro acrescente em suas anotações novas pesquisas e fatos que você achou interessante para complementar seus estudos.

\section{REFERÊNCIAS}

BRABAZON, T. Behavioural Finance: A new sunrise or a false dawn? In: SUMMER SCHOOL, 2000, Limerick, Ireland. Working Paper [...]. Limerick, Ireland:

University of Limerick, 2000.

FAMA, E. F. Efficient capital markets: a review of theory and empirical work. Journal of Finance, v. 25, n. 2, p. 383-417, may, 1970.

FERREIRA, D. D. M. et al. Neuroeconomia: Um apoio da neurociência à economia e à gestão do conhecimento. In: SIMPÓSIO DE EXCELÊNCIA EM GESTÃO E TECNOLOGIA - SEGeT, V., 2008, Resende. Anais [...]. Resende: AEDB, 2008. Disponível em: https://www.aedb.br/seget/arquivos/artigos08/527_Neuroe conomia[SEGeT_novo].pdf. Acesso em: 22 jul. 2018.

KAHNEMAN, D.; RIEPE, M. W. Aspects of investor psychology - Beliefs, preferences, and biases investment advisors should know about. Journal of Portfolio Management, v. 24, n. 4, p. 52-65, 1998.

KAHNEMAN, D.; TVERSKY, A. Prospect theory: an analysis of decision under risk. Econometrica, v. 47, n. 2, p. 263-291, mar. 1979. 
KAPLAN, R. S.; NORTON, D. P. Alinhamento: usando o BSC para criar sinergias. Rio de Janeiro: Elsevier, 2006.

LOWENSTEIN, G.; CAMERER, C.; PRELEC, D. A aurora da neuroeconomia. HSM Management, Barueri, ed. 67, p. 72-76, mar./abr. 2008.

MACEDO JR., J. S. Teoria do prospecto: uma investigação utilizando simulação de investimentos. 2003. 203 f. Tese (Doutorado em Engenharia de Produção) Universidade Federal de Santa Catarina, Florianópolis, 2003.

MARKOWITZ, H. Portfolio selection. Journal of Finance, v. 7, n. 1, p. 77-91, mar. 1952.

NONAKA, I.; TAKEUCHI, H. Criação de conhecimento na empresa. 14. ed. Rio de Janeiro: Campus, 1997.

SHARPE, W. F. Capital Asset Prices with and without Neative Holding. The Journal of Finance, v. 46, n. 2, p. 489-509, 1991.

SHEFRIN, H.; STATMAN, M. The disposition to sell winners too early and to ride losers too long: Theory and evidence. Journal of Finance, v. 40, n. 3, p. 777-790, 1985.

SHILLER, R. Exuberância irracional. São Paulo: Makron Books, 2000.

SHILLER, R. Human behavior and the efficiency of the financial system. In: TAYLOR, J.; WOODFORD, M. (ed.). 
Handbook of Macroeconomics. Amsterdam: Elsevier, 1999. v. 1, p. 1305-1340.

SMITH, V. L. et al. Experimental Tests of the Endowment Effect. Journal of Economic Behavior and Organization, v. 30, issue 2, p. 213-227, 1996.

THALER, R. Mental accounting and consumer choice. In: THALER, R. Quasi Rational Economics. New York: Russel Sage Foundation, 1985. p. 25-48.

TVEDE, L. The Psychology of Finance. Hoboken, NJ: John Willey and Sons, 2000.

TVERSKY, A.; KAHNEMAN, D. Judgment under uncertainty: Heuristics and biases. Science, v. 185, issue 4157, p. 1124-1131, sep. 1974. 


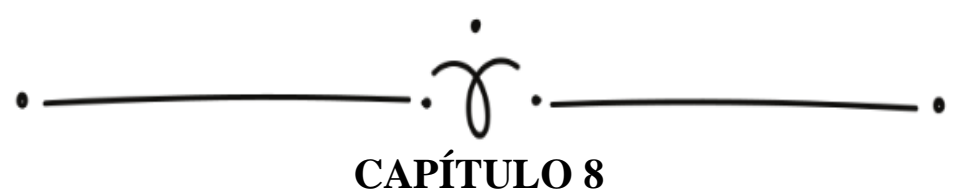

\title{
PESQUISAS DE NEUROMARKETING PARA A COMUNICAÇÃO VISUAL
}

\author{
Izabela Souza da Silva \\ Maria Goretti Fernandes \\ Ana Gabriela Lopes Fernandes \\ Elenilton Correia de Souza \\ João Adriano Correia Santos
}

\section{INTRODUÇÃO}

Na temática a seguir, você irá estudar sobre as pesquisas de neuromarketing para a comunicação visual. Esse conteúdo será extremamente importante para a sua vida profissional, uma vez que com o processo de globalização, estamos constantemente expostos a uma grande quantidade de propagandas e marcas.

Uma pesquisa realizada em 2007 pela ACNielsen (empresa mundial de pesquisa de marketing, com sede em Nova York), evidenciou que os entrevistados somente eram capazes de se lembrarem de, no máximo, 2,21 dos comerciais já vistos em toda a sua vida (LINDSTROM, 2010).

A análise dos resultados dos esforços de marketing e publicidade é de difícil mensuração, principalmente quando se utilizam métodos tradicionais de pesquisa, tais como as entrevistas qualitativas. Assim, para a melhor 
compreensão do comportamento humano e do comportamento do consumidor, não se pode ignorar a influência dos fatores biológicos sobre os seres humanos (NEIVA, 2012).

Em um experimento realizado pela Pepsi em 1975, conhecido como Pepsi Challenge (o desafio da Pepsi), milhares de mesas foram postas nos mais diversos supermercados e shoppings de várias partes do mundo e amostras não identificadas de Pepsi e de Coca-Cola foram oferecidas a mulheres, homens e crianças transeuntes. $\mathrm{O}$ resultado evidenciou que mais da metade das pessoas que participaram da enquete preferiram o sabor da Pepsi em relação ao da Coca-Cola. Todavia, questiona-se: porque a Pepsi não é a líder mundial de vendas no mercado de refrigerantes? Logo, esse estudo ressaltou que o consumidor não é tão racional quanto se pensava, bem como refletiu sobre o que ele pensa a despeito dos seus hábitos de compra (LINDSTROM, 2010). Tais questionamentos serão discutidos neste capítulo, onde trataremos de aspectos bioquímicos do cérebro e a sua relação com a comunicação visual e o consumismo.

\section{Prezado leitor, nesse exato momento após ter lido esse exemplo, você deve estar se perguntando: o que as empresas devem fazer para serem lembradas pelas pessoas?}

Para as empresas se destacarem no mercado consumidor, onde existem diversas marcas, é fundamental que ocorram adaptações e diferenciações frente à mesmice das organizações e, sobretudo, que correspondam e 
superem às exigências da sociedade. Deste modo, cita-se que a comunicação com o consumidor deve acontecer de forma mais intensa, conectando-se profundamente às suas necessidades, inovando e ultrapassando suas expectativas, firmando, assim, um forte vínculo. Nesse contexto, o marketing é uma batalha, não de produtos, mas sim de percepções, uma vez que não existem produtos melhores e nem piores, porém pode haver conceitos positivos ou negativos em relação a uma determinada marca (LINDSTROM, 2010).

Como o neuromarketing poderá contribuir para a comunicação visual? Quais as vantagens de utilizar seus métodos em propagandas e na comunicação visual?

O neuromarketing tem muito a contribuir para a comunicação visual. Neste campo são inclusos itens como a escolha de cores e as imagens a serem utilizadas, além de métodos investigativos cuja preocupação é a análise do movimento dos olhos. Sob o ponto de vista neurológico, em uma peça de designer gráfico, por exemplo, é possível obter uma informação confiável do produto ou serviço e que seja correlata aos desejos do cérebro humano. Tais concepções incentivam o aumento da competitividade entre as empresas, as quais auxiliam na elaboração de materiais mais condizentes, ao tempo em que motivam os consumidores (NEIVA, 2012).

Nesse contexto, o neuromarketing é a chave para se desvendar os pensamentos, sentimentos e desejos subconscientes que lideram as nossas decisões de compra, pois o cérebro é dominado por processos automáticos ao 
invés de pensamentos racionais e, desta forma, muito do que acontece no cérebro é mais próximo da esfera emocional do que a cognitiva. Consequentemente, a análise dos resultados dos esforços de marketing e publicidade são de difícil mensuração, principalmente quando se utilizam os métodos qualitativos de pesquisa, os quais envolvem subjetividade (LINDSTROM, 2010).

\subsection{O cérebro e a comunicação visual para consumir}

Camargo, neurocientista brasileiro, relata que o ser humano tem muito do comportamento animal em seus atos. Ele acredita que o homem é apenas mais desenvolvido que os chipanzés somente no tamanho do córtex cerebral, o qual é três vezes maior do que o dos primatas, indicando assim uma maior capacidade de raciocínio e consciência. Contudo, o estudioso descreve que esse fato não indica que o ser humano é totalmente racional (CAMARGO, 2010).

Muitos fatores confirmam a influência dos sentidos na comunicação visual. É importante saber que nossos sentidos captam aproximadamente 11 milhões de bits de informação por segundo, enquanto a parte consciente do cérebro é capaz de processar apenas 40 bits. Desse modo, o restante da informação é processado inconscientemente e, por isso, há uma grande diferença entre o que se processa de forma inconsciente e o que é expressado conscientemente (PRADEEP, 2010).

Em meio ao exposto, grande parte dos atos econômicos do ser humano é irracional. Tais atos, vinculados intrinsicamente ao consumismo, geram motivações físico-químicas que objetivam a proteção do 
corpo, a sobrevivência e a reprodução, configurando maneiras de manutenção da sobrevida gênica (CAMARGO, 2010).

Ao contrário do que se pensava, o comportamento humano é tão influenciado por fatores biológicos, tais como os órgãos, hormônios, influência genética, entre outros, quanto por fatores culturais e sociais. Ou seja, o homem possui mais características animais do que se imaginava (LINDSTROM, 2010).

\subsection{Compreendendo melhor o cérebro antigo}

Segundo Renvoisé e Morin (2007), o cérebro humano é dividido em três partes que foram originadas em épocas evolutivas diferentes e, portanto, suas funções são fundamentalmente distintas. Por sua vez, Corcoran (2007), caracteriza o cérebro humano em três partes:

a) cérebro "novo" (a parte mais evoluída), responsável por atividades como a lógica e o aprendizado;

b) cérebro "do meio" (o sistema límbico), responsável pelas emoções, estados de humor, entre outros;

c) cérebro réptil (o mais antigo dos três), que controla as funções de sobrevivência básica, como fome, respiração, reações de luta e distanciamento das situações de perigo.

Portanto, percebe-se que o cérebro antigo é quem dirige nossas decisões impulsivas de compra. Em virtude disso, as organizações, a fim de fortalecer a marca, fidelizar 
os clientes e aumentar as vendas, devem compreender e comunicar-se conforme a linguagem do cérebro antigo.

De acordo com Renvoisé e Morin (2007), o cérebro antigo responde a seis estímulos específicos:

1. Foco em si mesmo: $O$ cérebro antigo é extremamente egocêntrico e o uso de palavras como você é indicado, assim como mensagens que mostram claramente o benefício de usar o produto;

2. Uso de contrastes: $O$ cérebro antigo é sensível a contrastes claros, como antes/depois, perigoso/seguro, com/sem, rápido/devagar. Contrastes permitem que o cérebro antigo faça decisões rápidas e sem riscos. Sem estes, o cérebro entra em um estado de confusão que acarreta no atraso da tomada de decisão ou simplesmente em nenhuma decisão.

3. Uso de dados tangíveis e simples: $O$ cérebro antigo está à procura de dados familiares, concretos, imutáveis e reconhecíveis. O uso de mensagens complicadas, como palavras subjetivas, retarda o processo de decodificação da mensagem.

4. Posicionamento da parte mais importante da mensagem no início e a repetição dela no fim: $O$ cérebro está constantemente buscando conservar a energia vital e terá a tendência de esquecer a informação durante o meio do processo. Logo, o cérebro antigo tem afinidade em iniciar e finalizar as tarefas, e frequentemente ignora o que está no meio. 
5. Uso de emoções: Ao experimentar as emoções, um coquetel de hormônios inunda o cérebro e impacta as conexões sinápticas entre os neurônios, tornando-as mais rápidas e mais fortes. Como resultado, os eventos são facilmente lembrados quando experimentados com intensas emoções. Emoções são respostas automáticas ao estímulo sensorial. O cheiro de café, o som do oceano, ou a vista do pôr do sol, por exemplo, podem provocar uma resposta emocional inconsciente.

6. Uso da linguagem visual: $O$ cérebro antigo é extremamente visual. E o nervo óptico, que é conectado a ele, é quatro vezes mais rápido do que o auditivo.

A neurociência demonstra também, a título de curiosidade, que quando vemos algo parecido com uma cobra, o cérebro antigo nos alertará o perigo instantaneamente, em cerca de 2 milissegundos, no entanto, tardará cerca de 500 milissegundos até que a parte visual do neocórtex reconheça que se trata realmente ou não de uma cobra (RENVOISÉ; MORIN, 2007).

\section{A revolução 4.0 e o neuromarketing}

Em meio a tantos avanços globais, você considera a tecnologia como o cérebro ou o combustível para o neuromaketing?

Em meio a tantos avanços globais, você considera a tecnologia como o cérebro ou o combustível para o neuromaketing?

Para entender tal indagação, vamos adentrar em um novo campo que promete muitas mudanças na forma como 
compreendemos o mundo, as pessoas e os negócios: A revolução 4.0 e $\mathrm{o}$ neuromarketing. $\mathrm{O}$ cérebro, o comportamento humano e as ferramentas antigas, agora tendem a se manifestar com uma vestimenta diferenciada, mediada pela fronteira entre o passado e o futuro. As previsões futurísticas, que antes eram distantes, hoje começam a fazer sentido, principalmente através do mundo virtual, as quais colocam a humanidade em um patamar avançado de interação e desenvolvimento.

Esta revolução refere-se a uma nova organização dos processos produtivos associados à tecnologia, utilizando-se de ferramentas e métodos que interagem com o consumidor através de sistemas ciber-físicos, com o auxílio da internet. Com o avanço da ciência, essa transformação industrial permitirá a potencialização da velocidade e qualidade de produção. Todavia, sua implementação abre também um viés que pode causar impactos em toda conjuntura social, promovendo mudanças econômicas, empresariais, governamentais e na relação entre as pessoas e o mundo do trabalho (JUNIOR; SALTORATO, 2018).

Logo, considera-se que os indivíduos, dessa vez, devam assumir um papel mais efetivo e firmar o seu protagonismo frente as inovações tecnológicas, diferentemente do que se observou nas revoluções anteriores, onde possuía uma condição de simples coadjuvante, a fim de apossar-se e evoluir com essa nova perspectiva de trabalho para não perder sua autonomia. Assim, é preciso que haja uma integração do homem com tais tecnologias, uma vez que esse novo modelo dispõe de 
uma gama de possibilidades capazes de fabricar produtos mais eficientes e rápidos, e que respondam às necessidades individuais do consumidor (JUNIOR; SALTORATO, 2018).

Com o advento da internet e a evolução dos meios de comunicação, há maior número de pessoas interligadas e interagindo-se, seja via computadores, celulares ou outro tipo de objeto portátil. Essa nova perspectiva é um pontapé para os sistemas autônomos da economia manufatureira, pois permite que muitas das decisões, num futuro próximo, sejam tomadas sozinhas pelas máquinas, no entanto controladas remotamente pelo homem, o que possibilitará maior eficiência, flexibilidade e redução dos custos de operação (JUNIOR; SALTORATO, 2018). Pesquisas recentes trazem que as empresas que já implementaram o modelo de indústria 4.0 reduziram em até $30 \%$ no tempo dos processos (FIRJAN SENAI; FINEP, 2019).

Entretanto, existem desafios para sua implementação, dentre os quais incluem atuação conjunta da sociedade, iniciativa privada e do poder público em desenhar normas de utilização, controle, competitividade e segurança para o contexto socioeconômico (JUNIOR; SALTORATO, 2018). Além do mais, é imprescindível que haja um elo que aproxime a mente e os desejos do consumidor, entendido pelo conceito ampliado do neuromarketing, com a globalização, para então usufruir o que de melhor essas tecnologias possam oferecer e induzir o público ao consumo (SOUZA; POHL, 2018).

Em meio a tudo isso, enxerga-se que as demandas dos consumidores, aliadas às novidades do mercado 
produtivo mundial, culminarão na criação de novos modelos de negócios e serviços. Destarte, exigirá que as empresas ampliem sua visão e capacidade de conexão, em termos globais, tornando-se mais ágeis no lançamento de produtos para aumentar a sua competitividade e, sobretudo, que proporcione uma relação mais intima com o cliente (JUNIOR; SALTORATO, 2018).

Por fim, é necessário que haja mudanças culturais, expandindo os olhares para as novidades empreendedoras em tempo real. Além disso, vale salientar que a execução desse novo conceito não se trata da substituição do homem pela tecnologia, e sim até que ponto ela pode beneficiar as pessoas com eficácia e segurança (FIRJAN SENAI; FINEP, 2019).

\section{Então, você pode se questionar nesse exato momento: os estímulos visuais possuem maior impacto no cérebro do que qualquer outra coisa?}

Isso mesmo! Os estímulos visuais possuem grande impacto no cérebro, essa teoria é chamada de teoria do neurônio espelho. Segundo Pradeep (2010), essa teoria traz que, quando o indivíduo vê alguém praticando uma ação, automaticamente, o seu cérebro simulará a mesma ação.

De acordo com o neurocientista Ramachandran (2009), os neurônios espelho praticam uma simulação virtual da realidade, pois o nosso cérebro adota a perspectiva de outra pessoa e pode, inclusive, aprender apenas por meio da observação. Lindstrom (2010) corrobora tal afirmação, e elucida que esses neurônios não 
nos influenciam tão somente a imitar a outra pessoa, mas também são responsáveis pela empatia humana.

\section{As mensagens de marketing podem se conectar melhor com o consumidor através dos neurônios espelho?}

A resposta é sim! Segundo Pradeep (2010), a ativação dos neurônios espelho é a melhor forma de se conectar com o consumidor. Mostrar imagens que evidenciam o produto sendo consumido, a fumaça de um café quente, ou a refrescância de um copo d'água, a exemplo, provocam sensações cerebrais que atraem o indivíduo e o induz à experimentação.

Além disso, Camargo (2012) afirma que a presença de imagens com pessoas sorrindo e felizes disparam os neurônios espelho, fazendo com que o cérebro humano adote uma posição positiva em relação a elas. Contudo, deve-se ressaltar que o cérebro feminino possui mais neurônios espelho do que o cérebro masculino, e, por isso, as mulheres possuem mais empatia com os eventos que acontecem às demais pessoas.

Assim, Pradeep (2010) relata que é importante usar uma linguagem recíproca e colaborativa ao lidar com a publicidade dirigida às mulheres, tal como usar a primeira pessoa do plural. Outra sugestão é demonstrar uma figura feminina sociável, em grupos ou representá-la positivamente, desenvolvendo expressões de contatos visuais.

\subsection{A embalagem e o neuromarketing}


Atualmente, o termo dinâmica da embalagem é utilizado pelo designer Calver (2009), para se referir à funcionalidade da embalagem e àquilo que a diferencia das demais. O design de embalagem tem uma grande importância no processo de seleção do produto, sendo, dessa forma, um elemento fundamental no marketing.

Lucht apud Mestriner (2007) afirma que as empresas perceberam que a embalagem é capaz de atrair a atenção do cliente por meio de suas formas, cores, odores e texturas. Vislumbrou-se que, se corretamente trabalhada, a embalagem pode definir uma compra e fidelizar o consumista. A embalagem é, dessa forma, um elemento crucial para a comunicação com o consumidor, uma vez que no Brasil cerca de $83 \%$ das decisões de compra são firmadas no local da venda (MESTRINER, 2007).

Segundo a reportagem de Brat (2010) para o Wall Street Journal Online, quando você caminha pelas fileiras do supermercado, você pode não perceber, mas o seu corpo está passando por microscópicas mudanças fisiológicas em resposta às características dos produtos, desde a cor até o formato e a tipografia utilizada. Essas ferramentas do neuromarketing não podem apontar exatamente que emoções as pessoas sentem, contudo podem indicar algum vínculo emocional, e isso é exatamente o que as empresas estão à procura, a fim de conseguir e fidelizar mais clientes.

\section{Como o neuromarketing explica a existência dessas mudanças fisiológicas no organismo com relação aos produtos durante uma compra?}


Pradeep (2010) justifica que tais mudanças fisiológicas durante a compra foram herdadas dos nossos ancestrais. A habilidade de buscar e "scannear" o mundo ao nosso redor permitia saber quais os melhores frutos, presas e ferramentas seriam escolhidas.

A diretora de pesquisa da empresa de neuromarketing brasileira Forebrain, Souza (2011) destacou que, ao observar embalagens com um design atraente, foi visto que havia uma maior ativação do córtex pré-frontal ventromedial, do núcleo accumbens e do córtex cingulado, que são áreas pertencentes ao sistema da recompensa. A autora afirma que, no mercado atual, as necessidades básicas dos consumidores parecem estar satisfeitas, e os atributos dos produtos, tais como qualidade e funcionalidade, tornam-se cada vez mais homogêneos, por isso a diferenciação de um produto começa a aparecer em aspectos menos tangíveis, o qual se inclui o design (SOUZA, 2011).

\section{Assim, isso quer dizer que o designer de uma embalagem de uma mercadoria faz toda a diferença?}

Sim, é justamente isso que o pesquisador Pradeep analisou em seus estudos de 2010. Ele investigou a eficiência da embalagem, identificando e separando os diferentes elementos que contribuem para isso, a fim de observá-los individualmente. Os itens que compõe a embalagem, estudados tanto por Pradeep (2010) quanto por outros autores, serão descritos ao longo desse tema, conforme a descrição dos itens a seguir: 
a) As imagens das embalagens: o uso das imagens possui um grande impacto no subconsciente do consumidor. As imagens e os ícones criam um enorme apelo emocional. Isso ocorre porque o consumidor navega pelo oceano de mensagens semânticas e numéricas, procurando um ponto de referência emocional, chamado de "oásis de emoções" (onde nesse momento a razão tende a ficar de lado). Além disso, em todas as categorias de produtos existem temas comuns; uma embalagem chama mais atenção e desperta mais emoção através da demonstração da fonte do produto na embalagem. Por exemplo: em caixas de leite, as pessoas gostam de ver vacas. Nas caixas de suco de laranja, as pessoas gostam de ver laranjas. Em embalagens de produtos de saúde e beleza, os itens são bem aceitos quando há flores e gotas de orvalho (PRADEPP, 2010).

b) A tipografia das embalagens: as fontes decorativas e elaboradas retêm mais a atenção dos leitores, pois o esforço adicional necessário para ler as fontes complexas gera um processamento da informação mais profundo e, consequentemente, melhor lembrança. Além disso, fontes complexas também se mostraram eficientes quando se deseja passar uma percepção de que algo foi feito com grande esforço, neste caso usa-se o exemplo dos menus dos restaurantes e descreve que as fontes complexas dão a impressão ao leitor de que os pratos do cardápio também são mais elaborados e exigem um maior esforço para serem produzidos (PRADEPP, 2010).

Contudo, Dooley (2010) relata que o uso de fontes decorativas para textos longos pode gerar a desistência da 
leitura. Por isso, é melhor usar letras simples quando um texto necessita de um certo comprometimento por parte do leitor.

b) O número de itens existentes em uma embalagem: quando uma embalagem consiste em cinco ou menos grupos distintos de imagem, torna-se muito mais fácil para o cérebro processar a informação do que quando mais grupos estão presentes (PRADEPP, 2010).

c) O arranjo espacial das embalagens: o arranjo espacial dividido em dois grupos mostra-se mais eficiente para a decodificação da mensagem, utilizando-se um grupo semântico (palavras) e outro de imagens. O cérebro processa melhor o arranjo de imagens à esquerda e palavras à direita. Outro fator que se mostrou positivo é utilizar a descentralização dos elementos (PRADEPP, 2010).

e) As cores da embalagem: a cor é um item muito importante para a embalagem, já que trata-se de uma forma mais eficiente de discriminação que existe em um produto. Além disso, ressalta que a cor da embalagem auxilia na construção do posicionamento e da personalidade do produto ou da marca (MESTRINER, 2007). Outro ponto importante, que está correlacionado a cor, é a iluminação da área de exposição das embalagens, a qual demonstra ser um fator decisivo para o eficiente impacto neurológico, que atingirá o cliente. Desse modo, os estudos constataram que a cor se trata de um aspecto altamente mutável em relação à cultura estudada do consumidor (PRADEEP, 2010). 
Logo, podemos dizer que as cores utilizadas, as imagens, os tipos de fontes e o seu tamanho quando apresentadas nas embalagens podem influenciar na compra de um produto?

Sim, exatamente isso. As pesquisas demonstram que as nossas respostas são parcialmente fisiológicas, baseadas nos efeitos que as cores possuem sob o nosso sistema nervoso, e parcialmente influenciadas pelo ambiente em que vivemos e nossas experiências de vida.

Segundo Drew e Meyer (2008), autores do livro Color Management: A Comprehensive Guide for Graphic Designers, a cor possui atributos físicos, psicológicos e comportamentais e, dessa forma, desencadeia certas reações motoras, glandulares e conscientes no comportamento humano. Além disso, os autores afirmam que os efeitos fisiológicos da cor podem variar devido a alterações no seu matiz ou de saturação, que são, respectivamente, a intensidade e a pureza da cor (se há ou não a presença de branco, preto ou tons de cinza na sua formação).

Por exemplo, cores quentes como o vermelho, o laranja e o amarelo, têm maiores comprimentos de onda, exigindo mais energia para vê-las. É por esse motivo que essas cores chamam mais atenção. Elas também estimulam o cérebro e aumentam o batimento cardíaco e a respiração. Já as cores frias, como os tons de azul e verde, possuem comprimentos de onda menores e, por isso, são mais fáceis de serem absorvidas pelo olho humano. Como consequência, temos um efeito calmante e relaxante, além da diminuição do nosso metabolismo (MARKS, 2009). 
Segundo Camargo e Tauhata (2012), as pesquisas de neuromarketing demonstraram que combinações como o preto, o verde e o azul despertam a curiosidade; o verde e o dourado passam a sensação de sucesso; e o vermelho e laranja, remetem à credibilidade.

Já Lindstrom (2010), afirma que imagens de faces sorridentes fazem as pessoas quererem comprar mais subconscientemente. Por fim, Young (2011) considera que a falta de itens, tais como a fumaça saindo de um prato quente ou a falta do queijo derretido saindo da pizza, acarretam em emoções negativas em relação à embalagem.

O uso excessivo de diferentes tipos de fontes pode confundir os leitores, criando desordem e desestimulando a leitura, o ideal é que dois a três tipos de fontes sejam utilizadas nas embalagens (PRADEEP, 2010).

\section{Quanto a percepção das pessoas com relação a sabores dos produtos, também pode ser influenciada pelas cores das embalagens?}

Sim, pode. Trabalhos relatam que as cores escolhidas para a embalagem de itens alimentícios alteram a percepção do sabor pelo cliente. Em geral, amarelo e amarelo-esverdeado têm pouca avaliação de sabor, enquanto comidas laranja, vermelho, branco e rosa têm a percepção de serem mais doces. Em um estudo feito com vinhos, as cores branco e rosa nas embalagens eram percebidas como mais doces do que amarela, marrom e roxa, independentemente do seu sabor real. Qualquer comida tingida de uma cor que não seja natural será rejeitada pelos consumidores. Comidas e embalagens 
brancas quase não são escolhidas. Comidas e embalagens em tons de azul e verde devem ser elaboradas com cuidado, pois estes tons são associados ao mofo e por isso os consumidores as veem como tons falsos e não naturais. Devem-se evitar fazer embalagens azuis e roxas, pois muitas das frutas venenosas possuem estes tons. Vermelho e laranja são percebidos mais doces do que sucos de outras cores, principalmente os tons de maior saturação. Já em relação aos pães e cereais, espera-se tons dourados e marrons (DREW; MEYER, 2008).

Outro exemplo encontrado está relacionado ao fato de que as embalagens verdes passam a sensação de frescor e por isso são tão populares em cosméticos. Além disso, demonstram a imagem de um produto natural, saudável e ecologicamente correto (MARKS, 2009).

Dando continuidade aos estudos de Pradeep (2010) sobre as embalagens, os itens apresentados a seguir são:

f) A forma da embalagem: as embalagens com um design diferente e exclusivo são mais atraentes do que as demais, especialmente aquelas que estimulam o contato tátil. Além disso, a forma de uma embalagem é um item essencial para o seu destaque, pois ela deve ter um apelo visual e o formato deverá contribuir para reforçar a tendência do cérebro de simular a posse do produto e o prazer que este resultará. As embalagens mais confortáveis de serem manuseadas estimularam mais o cérebro humano em comparação as quais não foram desenvolvidas de forma ergonômica (PRADEEP, 2010). 
g) O tamanho da embalagem: os estudos de neuromarketing evidenciam uma forte relação entre preço aceitado, valor percebido e tamanho da embalagem. De acordo com essas pesquisas, quanto mais caro o produto, ou quanto maior o valor percebido, maior se espera que seja a embalagem, independentemente do tamanho do objeto de consumo. O importante é que o tamanho da embalagem seja coerente com o local onde ela estará inserida, como é o caso dos produtos de limpeza que geralmente têm um espaço restrito na área dos consumidores. Estes, implicitamente calculam o encaixe das embalagens com seus correspondentes locais de destino, e instantaneamente rejeitam a embalagem que apresenta um desencaixe (PRADEEP, 2010).

h) O revelamento do produto: as embalagens que se mostram mais eficientes são aquelas que revelaram o produto de alguma forma, tanto pela visão (alguma área transparente) quanto pelo sentido, fazendo com que o consumidor possa experimentá-lo por meio do olfato, tato, audição e/ou gosto (PRADEEP, 2010).

\section{i) A harmonia da mensagem na embalagem: o} sucesso da embalagem deve-se ao fato de que ela tenha uma congruência com a mensagem e o posicionamento da marca em questão, atuando como um reflexo da empresa no que diz respeito aos seus valores, metáforas, benefícios e sentimentos. A embalagem deve expressar a essência do produto e da marca para o consumidor explicitando esta mensagem em palavras na embalagem. A mesma deve 
reforçar os elementos chave da essência da identidade visual (PRADEEP, 2010).

\section{j) A redação publicitária: deve-se sempre destacar na} mensagem, a recompensa para o consumidor, pois é a ideia da recompensa que o motiva à ação. $\mathrm{O}$ uso de adjetivo torna a descrição do produto mais atraente e estes devem ser utilizados em descrições pequenas, porém não se pode utilizá-los quando se estiver chamando o consumidor para a ação, como dar instruções. A redação publicitária em qualquer outro lugar da embalagem deve ser de fácil compreensão, os verbos e substantivos movem o leitor adiante, enquanto os adjetivos e advérbios o atrasam. Os mesmos só devem ser utilizados quando forem essenciais para o entendimento da mensagem (DOOLEY, 2011).

\section{Qual é o mecanismo que ocorre com o consumidor ao utilizar a palavra: VOCÊ?}

Quando a palavra "você" é utilizada, o cérebro antigo do consumidor vai inconscientemente sentir a posse no produto e querer usá-lo. A mensagem se torna instantaneamente mais pessoal, e o seu consumidor sentirá que o produto foi desenvolvido para ajudá-lo a resolver a sua necessidade.

É importante fazer o uso da palavra "você" na elaboração das mensagens, pois o cérebro antigo tem características egoístas e egocêntricas, significando que os consumidores não ligam para o produto e sim para o que os produtos podem fazer por eles. Assim sendo, o melhor que se pode fazer para auxiliar o consumidor a entender as 
vantagens do produto é utilizar a palavra "você", que irá fazer toda a diferença. Por exemplo, não se deve escrever na embalagem: o sistema vai usar 50\% menos energia que os sistemas tradicionais. O indicado é escrever: você irá economizar $50 \%$ na sua conta de energia com este sistema (RENVOISÉ; MORIN, 2007).

\section{E quanto a existência de pontos específicos para a elaboração da identidade visual de um produto? Existe algum estudo ou considerações levadas em conta?}

Sim, exatamente. Segundo Pradeep (2010), os pontos essenciais na elaboração de uma identidade visual para as embalagens, a partir dos estudos de marketing, são:

Simplificar as embalagens de forma que não necessitem de muito esforço para a sua decodificação e que consumam menos recursos cognitivos. O cérebro humano requer $20 \%$ da energia do corpo humano, sendo o órgão que mais exige metabolicamente do corpo. Assim, qualquer mensagem de decodificação difícil será ignorada por ele. A exemplo, vemos as minimalistas embalagens da Apple.

$\checkmark \quad$ Ao tratar de produtos indispensáveis ao ser humano, é preciso providenciar uma mensagem ordenada, clara e com direções objetivas de uso, uma vez que o cérebro scaneia rapidamente a mensagem na busca do que procura. Isso se deve ao comportamento do cérebro voltado para o objetivo final, pois o lobo frontal comanda o que o corpo acha que é vital para si, ignorando o que não se demonstre satisfatório para a sua necessidade;

$\checkmark \quad$ Enfatizar o que é novo no produto; 
$\checkmark \quad$ Utilizar imagens e formatos palatáveis e emotivos que despertem emoções no consumidor e, consequentemente, que o façam lembrar e reagir mais facilmente à mensagem. Isso ocorre porque o cérebro humano é extremamente emocional;

$\checkmark \quad$ Prestar atenção especial ao odor da embalagem, principalmente ao retratar comidas. Deve-se, por exemplo, ter a certeza de que a embalagem não cheira a plástico.

\section{O que vimos neste conteúdo?}

- $\quad$ o cérebro humano foi dividido em três: 1) cérebro novo (a parte mais evoluída) responsável por atividades como a lógica e o aprendizado; 2 ) o cérebro do meio (o sistema límbico), responsável pelas emoções, estados de humor, entre outros; 3 ) o cérebro réptil (o mais antigo dos três), que controla as funções de sobrevivência básica, como fome, respiração, reações de luta e distanciamento das situações de perigo;

- A chegada da Revolução 4.0, seus impactos no processo produtivo e o uso da tecnologia digital como ferramenta de neuromarketing;

- $\quad$ Como as pesquisas de neuromarketing, sobretudo no campo da comunicação visual, influenciam no mercado consumidor. Itens como a escolha de cores, imagens e linguagem a serem utilizadas fazem parte de métodos investigativos, cujo objetivo é de se obter uma informação confiável a partir da análise do movimento dos olhos do consumidor sob um ponto de vista neurológico; 
- A eficiência de uma embalagem e os diferentes elementos que compõem a mesma são indispensáveis para atrair o consumidor para o produto.

- $\quad$ Os estudos de Pradeep em 2010, os quais descrevem as embalagens como princípios da neuromarketing, são estratégias imprescindíveis para a comunicação visual.

\section{Leitura complementar}

MLODINOW, L. Subliminal. New York: Pantheon Books, 2012.

KANDEL, E. Em busca da memória. São Paulo: Companhia das Letras, 2009.

Consulte os livros recomendados acima e faça um resumo sobre o que são mensagens subliminares e como a memória pode evocar o consumo de determinados produtos.

\section{REFERÊNCIAS}

BRAT, I. The emotional quotient of soup shopping. Wall Street Journal, New York, 17 feb. 2010. Disponível em: http://on.wsj.com/c7FHAG. Acesso em: 20 jul. 2018.

\section{CALVER, G. O que é design de embalagens? Porto} Alegre: Bookman, 2009.

CAMARGO, H.; TAUHATA, S. Como saber o que se passa na cabeça do consumidor? Pequenas Empresas \& Grandes Negócios, Rio de Janeiro, 2012. Disponível em: http://glo.bo/MhBseM. Acesso em: 15 mai. 2018. 
CAMARGO, P. Comportamento do consumidor: a biologia, anatomia e fisiologia do consumo. Ribeirão Preto: Novo Conceito, 2010.

CORCORAN, D. Neuromarketing: top 7 insights to unlocking your customer's brain for instant sales. Business Know-How, 19 sep. 2007. Disponível em: http://www.businessknowhow.com/marketing/neuromarke ting.htm. Acesso em: 15 jul. 2018.

DOOLEY, R. Convince with simple fonts. Neuroscience Marketing, 2010. Disponível em: http://www.neurosciencemarketing.com/blog/articles/simp le-fonts.htm. Acesso em: 05 jul. 2018.

DOOLEY, R. How to write taglines that double sales.

Neuroscience Marketing, 2011. Disponível em: http://bit.ly/vgpEBb. Acesso em: 02 mai. 2018.

DREW, J.; MEYER, S. Color management: a comprehensive guide for graphic desiners. Suíça: RotoVision Books, 2008.

FIRJAN SENAI; FINEP (org.). Indústria 4.0 no Brasil: oportunidades, perspectivas e desafios. Rio de Janeiro: [s.n], 2019.

JUNIOR, G. T.; SALTORATO, P. Impactos da indústria 4.0 na organização do trabalho: uma revisão sistemática da literatura. Revista Produção Online, Florianópolis, v. 18, n. 2, p. 743-769, 2018. 
LINDSTROM, M. Buyology: truth and lies about why we buy. New York: Broadway Books, 2010.

MARKS, T. Color harmony compendium. Beverly, MA: Rockport Publishers, 2009.

MESTRINER, F. Gestão estratégica de embalagem. São Paulo: Pearson Prentice Hall, 2007.

NEIVA, L. O neuromarketing e a comunicação visual. Universitas: Arquitetura e Comunicação Social, Brasília, v. 9, n. 2, p. 25-36, jul./dez. 2012. Disponível em: file:///C:/Users/ML/Downloads/1985-9858-3-PB.pdf. Acesso em: 23 jul. 2018.

PRADEEP, A. K. The buying brain: secrets for selling to the subconcious mind. Hoboken, NJ: John Wiley \& Sons, 2010.

RAMACHANDRAN, V. The neurons that shaped the civilization. TED, 2009. (vídeo). Disponível em: http://www.ted.com/talks/lang/en/vs_ramachandran_the_n eurons_that_shaped_civilization.html. Acesso em: 20 mai. 2018.

\section{RENVOISÉ, P.; MORIN, C. Neuromarketing:}

understanding the buy buttons in your customer's brain. 2 . ed. Nashville, TN: Thomas Nelson, 2007.

SOUZA, A. Quem vê embalagem não vê... Forebrian, 21 mar. 2011. Disponível em: 
http://forebrain.com.br/foreblog/2011/03/quem-veembalagem-nao-ve/. Acesso em: 18 mai. 2018.

SOUZA, B. H. de; POHL, R. Estratégias do

Neuromarketing - Conhecendo suas técnicas de persuasão. PMKT - Revista Brasileira de Pesquisas de Marketing, Opinião e Mídia, São Paulo, v. 11, n. 2, p. 236-244, mai.ago. 2018.

YOUNG, S. Neuroscience explains the emotional buy.

Packaging Strategies, 11 jul. 2011. Disponível em: http://bit.ly/xplzSh. Acesso em: 20 jul. 2018. 


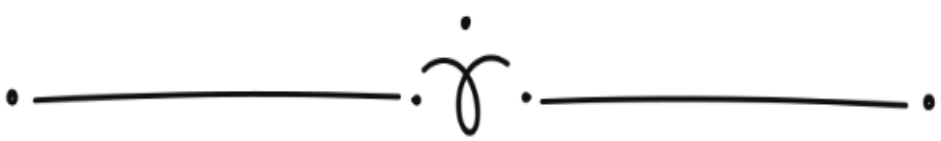

CAPÍTULO 9

\title{
ESTRATÉGIAS E RESULTADOS ATRAVÉS DO NEUROMARKETING
}

\author{
Izabela Souza da Silva \\ Maria Goretti Fernandes \\ Silvia Pessoa de Freitas Pedrosa de Oliveira
}

\section{INTRODUÇÃO}

O presente capítulo irá abordar sobre as estratégias e resultados esperados através do neuromarketing. A temática em questão envolve os cinco sentidos humanos (visão, audição, paladar, olfato e tato), bem como as estratégias do mercado utilizadas através desses sentidos. Você irá estudar a importância da questão sensorial nas vendas através do inconsciente, o planejamento estratégico com base no neuromarketing e a tomada de decisão. Além da influência do marketing sensorial e as informações do inconsciente na hora da compra.

\subsection{Utilizando os sentidos para estratégias de mercado}

Ao discutirmos sobre os sentidos para a estratégias de mercado através do neuromarketing, abordaremos a experiência sensorial que surge do conceito marketing sensorial, opondo-se ao conceito de marketing tradicional. O marketing tradicional foca nos atributos e na performance do produto ou serviço, ele é considerando a decisão racional 
dos consumidores. Entretanto, quando o neuromarketing baseia-se na experiência sensorial, este recebe o nome de neuromarketing sensorial; sendo aquele que transmite a mensagem do produto ou serviço de várias formas e tendo em conta a decisão emocional dos consumidores.

O uso dos sentidos através do neuromarketing tem sido bastante explorado e discutido ao longo dos últimos anos, uma vez que está diretamente relacionado com a aplicação dos sentidos humanos na área do marketing. São vários os autores que defendem a importância da percepção sensorial, de modo a compreender e satisfazer corretamente os desejos e necessidades dos consumidores influenciando nas estratégias de vendas (SINGHAL; KHARE, 2015).

Sabe-se que os cinco sentidos são essenciais na vida dos seres humanos, pois fazem as pessoas viverem e terem opinião sobre o que os rodeiam, o que acentua a ideia de que o marketing sensorial pode contribuir para a percepção do consumidor sobre os produtos e serviços de que usufrui. $\mathrm{O}$ uso do marketing sensorial é uma atividade que se concentra na compreensão da percepção do consumidor, partindo dos estímulos sensoriais deste e interpretando-os. A relação entre o consumidor e um dado produto ou serviço pode ser fortalecida com base numa experiência sensorial que explore os cinco sentidos humanos. Por isso, a percepção do consumidor com relação a um produto é mais intensa se for composta por experiências visuais, auditivas, gustativas, olfativas e táteis, o que faz com que uma experiência seja cinco vezes mais rica (SINGHAL; KHARE, 2015). 


\section{Então, o neuromarketing pode utilizar os cinco sentidos humanos do consumidor para traçar suas estratégias de mercado?}

Isso mesmo, essa é uma técnica utilizada pelo neuromarketing para usufruir dos cinco sentidos humanos no relacionamento com o consumidor. $\mathrm{O}$ neuromarketing sensorial passou a utilizar os sentidos devido ao aumento da relação entre o consumidor e o produto ou serviço; essa relação ficou mais intensa após a utilização de experiências multissensoriais. O principal defensor desta afirmação foi Martin Lindstrom (2013), que provou com os seus estudos a relevância dos cincos sentidos no marketing e importância emocional que estes podem trazer para a imagem das marcas, produtos e serviços na mente dos consumidores.

Quando se utilizar os cinco sentidos humanos para influenciar a decisão de compra do consumidor conseguese atingir uma nova imagem no mercado. A aplicação dos cinco sentidos humanos na imagem e identidade da marca ou de um produto contribuem para uma relação emocional do consumidor com a mesma e afeta o seu comportamento na compra de um produto ou serviço (CIAN; CERVAI, 2011; HULTÉN, 2013; PAWASKAR; GOEL, 2014; SPENCE, 2015).

Tomando como base esses conceitos, o neuromarketing passar a considerar o uso de experiências multissensoriais, desenvolvendo estratégias para cada sentido, que por sua vez, possam se relacionar entre si numa só experiência. Essa estratégia oferece uma experiência que se destaque na vida consumidor (KRISHNA, 2015). Por isso, o neuromarketing sensorial permite atrair os clientes 
de uma forma diferente, partindo da emoção e da ativação e/ou criação de memórias para traçar estratégias de mercado (ZUDHAKAR; SHETTY, 2014).

\subsection{O sentido da visão}

Quando se utiliza os sentidos como forma de estratégias de mercado para a venda de uma marca ou produto, o sentido visual é o primeiro que se evidencia. Este sentido domina os outros sentidos, na medida em que é mais apelativo e sugere a primeira opinião que o consumidor irá construir sobre a marca ou produto. Dessa forma, o estímulo sensorial da imagem é um elemento muito utilizado pelo neuromarketing, uma vez que este adquire várias formas de utilização, e domina os outros sentidos humanos nas decisões de compra do consumidor (PAWASKAR; GOEL, 2014).

\section{Você pode estar se perguntando nesse exato momento: será que o sentido visual é um dos mais importantes nas estratégias de mercado?}

Sim, a visão é um sentido importantíssimo e que provoca aos indivíduos uma necessidade de sentir os produtos ou serviços que os rodeiam. Isto porque, a visão é um sentido que condiciona precocemente a opinião do consumidor face a uma marca, produto ou serviço, e que o faz interpretar só por ver o produto, e sem o sentir. Vale lembrar também que o elemento da cor é uma ferramenta importante do sentido visual, por isso, a escolha da cor pode 
promover comportamentos, sentimentos e formas de agir, diferenciando assim os produtos (AMSTEUS et al., 2015).

Pode-se afirmar que a visão é o sentido mais dominante utilizada nas estratégias de mercado, na medida em que contamina diretamente o pensamento do consumidor através da cor, do design, de frases ou até das embalagens dos produtos. O estímulo visual é, assim, um componente importante que abrange a imagem da marca, e que pode ser trabalhado a partir da cor, de gráficos, de letras, de embalagens e da construção de logótipos, podendo fazer parte da estratégia de uma empresa. Muitos consumidores procuram as marcas com base no elemento da cor, mas a mesma somente se torna autêntica se for acompanhada pelos elementos que a fazem ganhar forma, como é o caso do design do produto que tem um grande impacto no comportamento de cada indivíduo (HULTÉN, 2013).

\section{Como a neurociência explica a correlação do sentido visual na decisão do consumidor?}

A neurociência explica que o sentido visual auxilia o funcionamento do cérebro do indivíduo, na medida em que a visão ajuda a identificar e a localizar o que se ver.

Cerca de $83 \%$ de todo o aprendizado ocorre através da visão, devido à rápida percepção que temos através dela, esse sentido é um dos maiores responsáveis pelas decisões na hora da compra. O estudo de Blessa (2011) afirmou que a visão é o primeiro sentido humano a destacar-se no processo de escolha, pois é o primeiro a estimular o cérebro na direção do produto. Para Januzzi e Pacagnam (2009), 
esse sentido proporciona aos consumidores mais informações do que qualquer outro, sendo um importante meio de explorar sua percepção sobre o ambiente.

Por isso, para que uma marca seja alvo do pensamento do consumidor através do sentido visual, é essencial utilizar todos os elementos que fazem parte da criação de uma imagem, tais como: a cor, o design, a textura e as embalagens dos produtos. O sentido visual passa de imediato uma mensagem ao consumidor sobre a marca de um produto, e se esta for trabalhada na sua totalidade poderá manipular positivamente a percepção do consumidor na hora da compra, pois o que está em causa não é apenas o consumidor ver, mas sim como ele ver (LINDSTROM, 2005; RUPINI; NANDAGOPAL, 2015).

\subsection{O sentido da audição}

No que diz respeito ao sentido auditivo, é comum a utilização das relações emocionais que os indivíduos têm com as músicas, ligando uma música específica a uma marca. O estímulo sensorial do som é um dos sentidos mais utilizados pelas marcas, este é o segundo sentido que se destaca, contribuindo para o diálogo da marca com o consumidor. A marca de áudio deve ser corretamente aplicada, podendo ser utilizada de várias formas e em diversos contextos, uma vez que o som pode ser criado através de vários formatos introduzidos em diferentes locais e contextos, por exemplo: nas lojas, nas campanhas publicitárias, nas apresentações interativas da marca, nos meios de comunicação e nos suportes publicitários (HAYZLETT, 2015). 
Se o som é o segundo sentido mais importante do corpo humano, como este pode ser utilizado nas estratégias de neuromarketing?

O som pode ser utilizado com o intuito de proporcionar várias experiências sensoriais ao consumidor, por isso, o som pode ser utilizado através de vários formatos, como é o caso da expressão sonora do jingle, da voz ou até da música, que. A utilização do som de forma consciente pode contribuir para o sucesso e distinção de uma empresa e, por consequência, para caracterização de sua marca, produtos ou serviços, gerando experiências auditivas inesquecíveis (PAWASKAR; GOEL, 2014).

\section{Uma poderá empresa poderá utilizar o sentido auditivo} para maximizar o valor emocional de uma música a imagem de sua marca, produto ou serviço?

Exatamente. A imagem da marca poderá usufruir do sentido auditivo como uma estratégia para maximiza o valor emocional que o consumidor tem com a música ou com o som. Este tipo de estratégia auditiva leva em consideração que a reação do consumidor é originada por sentimentos como a presença da música, da voz e do som possuem um papel fundamental no nível de satisfação de uma experiência por parte do consumidor (PAWASKAR; GOEL, 2014).

A ligação entre a marca, produto ou serviço e o consumidor pode, assim, ser influenciada pelo sentido auditivo, que origina novas afeições e entusiasmos perante um determinado produto (RUPINI; NANDAGOPAL, 2015). Segundo Lang (2015), muitas organizações 
recorrem ao sentido auditivo para proporcionar experiências sensoriais ao consumidor, fazendo com que este opte pelo produto da respetiva marca, sendo o som uma percepção auditiva única.

É o uso desta percepção que leva uma marca a desenvolver uma imagem distintiva, visto que o som tem a capacidade de levar o consumidor a criar novas imagens e pensamentos. O sentido auditivo chama a atenção do consumidor a um nível emocional específico e intenso, tendo em vista que o som pode potencializar a percepção sensorial da imagem de uma marca ou produto. A audição é tida como passiva, mas o ato de escurar é um gesto ativo, sendo este o responsável por criar a experiência sensorial do consumidor, conseguindo criar uma relação original entre os componentes: marca, produto, serviço e consumidor (LINDSTROM, 2005).

\section{Como o estímulo auditivo pode influenciar o ambiente de uma compra? Como isso acontece?}

$\mathrm{O}$ ambiente de compra pode ser influenciado pela audição, pois a música pode criar um envolvimento com o ambiente da venda, podendo elevar ou depreciar a atmosfera da mesma (BLESSA, 2011). A utilização de músicas em ambientes comerciais reforça a imagem da loja e demonstra seu posicionamento perante os clientes e, dessa forma, influencia no consumo, pois quando a música é empregada corretamente, a mesma pode possibilitar um ambiente leve, descontraído e agradável, sendo capaz de criar uma identidade (JANUZZI; PACAGNAM, 2009). 


\subsection{O sentido gustativo}

Quanto ao sentido gustativo, as marcas, produtos ou serviços utilizam muito os tipos de gostos existentes, tais como o salgado, o ácido, o doce e o amargo, criando-se a relação com vários segmentos-alvo. O estímulo sensorial do palato consegue promover uma experiência sensorial através da sua associação com os outros sentidos, pois o paladar é um dos sentidos que mais se distingue emocionalmente, relacionando-se frequentemente com os outros (RUPINI; NADAGOPAL, 2015).

\section{Qual seria a explicação para o paladar ser considerado o sentido mais emocional e promover um maior número de interações sensoriais?}

A resposta está no fato do sentido do gosto ser capaz de proporcionar com facilidade uma interação entre os consumidores com a marca, produto ou serviço. Isto porque, é visível, as ligações que este sentido permite criar com os outros sentidos, e a relação pessoal que é adquirida entre as empresas e os seus clientes ao utilizar o paladar (RODRIGUES; HULTÉN; BRITO, 2011).

Além disso, o paladar desencadeia uma experiência multissensorial, evidenciando uma marca ou produto no mercado, baseando-se num convívio constituído por diferentes diálogos de sabores. Uma vez que o sentido do gosto está cada vez mais a ser explorado pelas empresas, tendo em vista a sua complexidade e a sua contribuição para a construção de uma imagem da marca ou produto 
incomparável, que se diferencia rapidamente dos seus concorrentes (LINDSTROM, 2005).

O palato é um dos sentidos humanos que faz parte da experiência multisensorial do consumidor. Como este deve ser utilizado pelo neuromarketing quanto ao conceito de emoção para fortalecer a imagem de uma empresa, do seu produto ou serviço?

O sentido do gosto deve fazer parte da experiência gustativa do consumidor e ajudar na construção da imagem de uma marca, produto ou serviço. Essa construção deve ser baseada na vertente emocional, e o neuromarketing utiliza essa relação com o consumidor de forma positiva (PAWASKAR; GOEL, 2014; AIRIKKA, 2014). Ao produzir uma marca multissensorial a empresa cria determinadas convicções, sentimentos, concepções e opiniões que levam à formação de uma imagem na mente do consumidor. É esta a razão que manifesta o interesse das empresas em utilizar todos os sentidos, em particular o sentido do gosto que gera emoções e opiniões íntimas e autênticas (ZUDHAKAR; SHETTY, 2014).

\subsection{O sentido do olfato}

De acordo com Blessa (2011), o olfato após a visão é sentido com maior facilidade para despertar emoções. Através do estímulo deste sentido pode-se criar personalidade ao ambiente, despertando lembranças, desejos e sentimentos nos consumidores. Criar um aroma específico e único fará com que o consumidor passe a lembrar da marca sempre que senti-lo. 
O sentido olfativo é diretamente associado ao estado de espírito do consumidor, através de sensações de conforto e de tranquilidade geradas pelo diferente uso de aromas. No estímulo sensorial do olfato, a variante sensorial prende-se muitas vezes com as memórias de experiências do consumidor, o que viabiliza a marca relacionar experiências sensoriais no passado, presente e futuro, dado que um dos principais benefícios do olfato é a sua agilidade em trazer memórias passadas onde a mesma experiência olfativa foi vivenciada (ZUDHAKAR; SHETTY, 2014).

$O$ olfato vem a ser um tipo de experiência antecipada que o consumidor pode experimentar, sendo o cheiro um dos primeiros sentidos a funcionar como alerta para o ser humano, e para o equilíbrio do seu bem estar. $\mathrm{O}$ olfato é um meio para atingir reações emocionais, sendo avaliado como o sentido que mais se aproxima do ato emocional do indivíduo (BRADFORD; DESROCHERS, 2009).

Além disso, os odores possuem, condições que favorecem um sentimento de nostalgia e combinam dimensões que podem ser positivas ou negativas. Uma vez que odores agradáveis aumentam o tempo que os consumidores passam nos ambientes de consumo, ao passo que odores desagradáveis geram comportamentos de fuga. O olfato é um estímulo importante no ponto de venda, se o odor não for agradável os clientes não permanecerão nele. Além disso, os odores remetem à nostalgia, podendo despertar boas lembranças e assim aproximar ainda mais o consumidor (JANUZZI; PACAGNAM, 2009). 
Esse sentido exerce grande influência no comportamento do ser humano, iniciando essa influência desde o seu nascimento e sendo reforçada quando utilizada para associar a imagem de marcas como elemento de comunicação entre o passado, o presente e o futuro do indivíduo (BRADFORD; DESROCHERS, 2009).

Além disso, o olfato está relacionado com o prazer e satisfação, bem como está ligado às recordações e sensações do ser humano. Por isso, o sentido olfativo alerta ao consumidor sobre a possibilidade de vivenciar novas experiências, levando em consideração as experiências vividas no passado (RUPINI; NADAGOPAL, 2015).

\section{Como o olfato pode fazer uma comunicação entre o consumidor e o produto? As memórias evocadas por um cheiro ou odor podem atuar contra ou a favor de uma marca?}

De acordo com Pawaskar e Goel (2014), o olfato é um sentido importante para a comunicação entre o consumidor e um produto, sustentando o conceito de que a imagem da marca ganha em desenvolver experiências sensoriais olfativas. Por outro lado, o sentido do olfato serve também como um obstáculo em certas experiências sensoriais, na medida em que cada indivíduo tem memórias diferentes, fazendo um julgamento diferente da experiência olfativa.

Existe uma relação do olfato com a memória que é estimulada por aromas, tornando-se uma importante ferramenta de lembrança na memória coletiva. A memória é parte integrante da vida do consumidor e acompanha o dia 
a dia, gerando sensações que comprometem o seu comportamento com as marcas (VIDAL; WOLFF, 2014).

Apesar do olfato ser um sentido controverso, uma vez que nos leva a relacionar memórias positivas ou negativas em experiências atuais, é um estímulo que pode atuar a favor da imagem da marca, e lançar novas memórias ao consumidor, uma vez que os cheiros evocam imagens, sensações, memórias e associações (LINDSTROM, 2005).

\subsection{O sentido do tato}

O sentido tátil tem como propósito proporcionar ao indivíduo a experiência de sentir o produto, desde as suas texturas até às suas formas. A percepção multissensorial de uma marca ou de um produto está completa quando o sentido tátil está presente. O tato desempenha um papel crucial no comportamento do consumidor, e em todo o ambiente sensorial, por ser um sentido que estabelece o contato mais direto entre o consumidor e um dado produto. As marcas que fazem opção por experiências táteis, conseguem aumentar o reconhecimento da sua imagem tanto no mercado como junto do consumidor, visto que usam um marketing que provém de experiências físicas (KRISHNA; ELDER; CALDARA, 2010; PAWASKAR; GOEL, 2014).

Então, você nesse exato momento, pode estar se perguntando: o sentido do tato pode influenciar o consumidor ao utilizá-lo para explorar um determinado produto? 
Sim, o sentido tátil pode influenciar o consumidor, uma vez que este é um desejo intrínseco da pessoa em interagir com um produto ou serviço. A experiência tátil permite um contato direto entre o produto e o indivíduo, tornando mais provável a oportunidade da compra (KEIF; STONEMAN; TWOMEY, 2015).

É justamente com o objetivo de se comunicar com o consumidor a partir de um componente físico, que as marcas utilizam o sentido tátil, pois este sentido traduz o componente físico do ser humano, que liga a informação e sensação sobre um determinado produto a uma experiência tátil e psicológica (RUPINI; NANDAGOPAL, 2015).

De acordo com Krishna (2006), outra característica que destaca o sentido do tato, é a sua influência na aprendizagem do ser humano perante a forma como age e se move no espaço, e como lida com os outros. É esta vertente física que pode tornar a imagem da marca numa imagem com mais dimensões, uma vez que os elementos táteis permitem que o órgão sensorial englobe o contato físico num processo de compra de um produto ou serviço. O tato é o meio através do qual permite ao consumidor conhecer as características físicas do produto. Essa interação física gera sensação antecipada de posse do produto e influencia diretamente a decisão de compra, sendo esta indispensável para esse processo (KOTLER, 2015; HULTÉN, 2013).

\subsection{A influência dos cinco sentidos humanos no mercado consumidor}


Desse modo, quanto mais sentidos as marcas utilizarem para vender, mais força estas vão ter para entrar na mente do consumidor. A criação de uma marca de sucesso, com uma imagem estratégica, pode partir da utilização dos cinco sentidos. (ZUDHAKAR; SHETTY, 2014).

Todos os sentidos humanos devem ser utilizados na sua totalidade, e devem fazer parte da construção da marca da empresa para que esta apresente uma imagem única e inconfundível num determinado mercado. Devendo-se lembrar que antes do cliente tomar uma decisão sobre uma marca, ele age e pensa através dos cinco sentidos. Por isso, para que as marcas possam satisfazer de forma inovadora o consumidor, deve-se criar experiências multissensoriais que surpreendam o cliente. Partindo-se do princípio que o indivíduo irá vivenciar algo que vai para além da sua expectativa, a sua satisfação irá se transformar em desejo (PAWASKAR; GOEL, 2014).

\section{Então, o sentido humano pode favorecer positivamente o consumo de uma marca, produto ou serviço?}

Exatamente, diante de tudo que foi apresentado pela literatura consultada, pode-se afirmar que cada sentido humano origina diferentes sensações e diferentes experiências sensoriais podendo assim ser utilizado com grande sucesso para as estratégias de mercado. A experiência multissensorial da marca recorre a estratégias de imagem, som, palato, odor e tato para o fortalecimento da imagem das marcas ou produtos no mercado. As marcas, os produtos e os serviços devem optar por utilizar 
estratégias baseadas nos cinco sentidos, com o intuito de obterem sucesso no mercado e passarem uma imagem sólida e, emotiva, isto porque já vimos que a marca emocional passa pelo preenchimento das necessidades dos consumidores (JOSHI; NEMA, 2015).

Sendo assim, as estratégias utilizadas pelo neuromarketing partem dos desejos e necessidades dos clientes, sendo essa a melhor forma de captar o pensamento e a realidade do consumidor. $\mathrm{O}$ despertar dos sentimentos e comportamentos devem ser influenciados pela interação com os sentidos humanos. Para que isso aconteça, a empresa deve cuidar da sua imagem, e transformá-la num produto que sensibilize os consumidores a partir dos cinco sentidos, porque cada indivíduo tem uma reação diferente e os instintos estão em constante mudança (TADIC; SUCA, 2015).

Para uma melhor compreensão do que foi estudado a figura 2 apresenta um resumo das expressões sensoriais provocadas pelas sensações dos cinco sentidos.

Diante desse contexto, o neuromarketing dos sentidos quando estrategicamente bem utilizado pela empresa poderá proporcionar uma ligação com o consumidor, e fazer com que este se relacione com o seu produto ou serviço, e que estes passem a ser a primeira escolha do cliente. Surgindo dessa forma, uma inovação na estruturação de um novo canal de comunicação interativo, que se baseia na emoção que o consumidor tem ao ver, ouvir, experimentar, cheirar e sentir o produto ou serviço. Toda essa estratégia faz com que a imagem da empresa surpreenda e agrade o consumidor. Assim, um cliente 
satisfeito é um fator imprescindível para que este seja leal, e que a imagem desta se torne cada vez mais forte (PAWASKAR; GOEL, 2014).

\section{O que vimos neste conteúdo?}

- O neuromarketing ao tomar como base a experiência sensorial, este recebe o nome de neuromarketing sensorial.

- $\quad \mathrm{O}$ uso dos sentidos no neuromarketing tem sido bastante explorado e discutido ao longo dos últimos anos, uma vez que está diretamente relacionado com a aplicação dos sentidos humanos na área do marketing.

- Os cinco sentidos humanos devem ser utilizados na sua totalidade, e devem fazer parte da construção da marca da empresa para que esta apresente uma imagem única e inconfundível num determinado mercado.

- As estratégias utilizadas pelo neuromarketing partem dos desejos e necessidades dos clientes, sendo essa a melhor forma de captar o pensamento e a realidade do consumidor.

\section{Leitura complementar}

VIDAL, H. S.; WOLFF, L. B. Marketing sensorial olfativo: uma ferramenta de aumento da percepção de valor e fidelização de marca. Revista Escola de Negócios, v. 2, n. 1, p. 77-105, 2014. 
HULTÉN, B.; BROWEUS, N.; DIJK, M. Sensory Marketing. New York: Palgrave Macmillan, 2009.

Para ampliar suas pesquisas em marketing sensorial e experiências utilizando os sentidos, recomenda-se a leitura complementar acima.

\section{REFERÊNCIAS}

\section{AIRIKKA, S. M. The role of emotional branding in} building brand personality from consumer perspective. 2014. 113 f. Dissertation (Master's Degree of Science International Marketing and Business Development) School of Business, Lappeenranta University of Technology, Lappeenranta, Finlândia, 2014.

AMSTEUS, M. et al. Colors in Marketing: A Study of Color Associations and Context (in) Dependence.

International Journal of Business and Social Science, v. 6, n. 3, p. 32-45, mar. 2015.

BLESSA, R. Merchandising no ponto-de-venda. 4. ed. São Paulo: Atlas, 2011.

BRADFORD, K. D.; DESROCHERS, D. M. The Use of Scents to Influence Consumers: The Sense of Using Scents to Make Cents. Journal of Business Ethics, v. 90, p. 141-153, 2009.

CIAN, L.; CERVAI, S. The Multi-Sensory Sort (MuSeS) A new projective technique to investigate and improve the 
brand image. Qualitative Market Research: An

International Journal, v. 14, n. 2, p. 138-159, 2011.

HAYZLETT, J. The language of Audio Branding. American Marketing Association, p. 1-4, 2015.

HULTÉN, B. Sensory cues as in-store innovations: Their impact on shopper approaches and touch behaviour.

Journal of Innovation Management, v. 1, n. 1, p. 17-37, 2013.

JANUZZI, Ulisses Amarildo; PACAGNAM, Mario Nei. Atmosfera de Loja: Uma análise sobre a abordagem do conceito nas produções acadêmicas no Brasil e os modelos teóricos adotados em suas pesquisas. Múltiplo Saber, Londrina, v. 5, n. 1, p. 1-12, set. 2009. Disponível em: https://www.inesul.edu.br/revista/arquivos/arqidvol_6_1253738428.pdf. Acesso em: 26 jul. 2018.

JOSHI, A.; NEMA, D. G. Emotional branding: A new way to create brand loyalty for FMCG Companies. Journal of Management Value \& Ethics, v. 5, n. 2, p. 93-100, 2015.

KEIF, M. G.; STONEMAN, A.; TWOMEY, C. Consumer perception of tactile packaging: a research study on preferences of soft touch and rise coatings in cosmetic packaging. Journal of Applied Packaging Research, v. 7, n. 1, p. 59-72, 2015. 
KOTLER, P. As minhas aventuras no marketing.

Lisboa: Gestãoplus Edições, 2015.

KRISHNA, A. A commentary on "the senses in anthropological and marketing research: investigating a consumer-brand ritual holistically". Journal of Business Anthropology, v. 4, n. 1, p. 31-35, 2015.

KRISHNA, A. Interaction of senses: the effect of vision versus touch on the elongation bias. Journal of Consumer Research, v. 32, n. 4, p. 557-566, 2006.

KRISHNA, A.; ELDER, R. S.; CALDARA, C. Feminine to smell but masculine to touch? Multisensory congruence and its effect on the aesthetic experience. Journal of Consumer and Psychology, v. 20, issue 4, p. 410-418, oct. 2010.

LANG, J. T. Music and consumer experience. In: COOK, D. T.; RYAN, J. M. (ed.). The Wiley Blackwell Encyclopedia of Consumption and Consumer Studies. Hoboken, NJ: John Wiley \& Sons, 2015. Disponível em: https://onlinelibrary.wiley.com/doi/epdf/10.1002/9781118 989463.wbeccs177. Acesso em: 05 ago. 2020.

LINDSTROM, M. Brand sense: os segredos sensoriais que nos levam a comprar. Lisboa: Gestãoplus Edições, 2013.

LINDSTROM, M. Broad sensory branding. The Journal of Product and Brand Management, v. 14, n. 2, p. 8487, 2005. 
PAWASKAR, P.; GOEL, M. A conceptual model: Multisensory Marketing and Destination Branding. Procedia Economics and Finance, v. 11, p. 255-267, 2014.

RODRIGUES, C.; HULTÉN, B.; BRITO, C. Sensorial brand strategies for value co-creation. Innovative Marketing, v. 7, n. 2, p. 40-47, 2011.

RUPINI, R. V.; NANDAGOPAL, R. Sensory branding: multisensory experience. Advances in Economics and Business Management, v. 2, n. 10, p. 979-983, 2015.

SINGHAL, D. S.; KHARE, K. Does sense reacts for marketing - sensory marketing. International Journal of Management, IT and Engineering, v. 5, n. 5, p. 1-13, may 2015.

SPENCE, C. Eating with our ears: assessing the importance of the sounds of consumption on our perception and enjoyment of multisensory flavour experiences. Flavour Journal, v. 4, n. 3, p. 1-14, 2015.

TADIC, D. P.; SUCA, S. Comparate analysis of the emotional and cultural branding models. International Proceedings of Social and Behavioral Sciences, v. 3, n. 1, p. 20-27, 2015.

VIDAL, H. S.; WOLFF, L. B. Marketing sensorial olfativo: uma ferramenta de aumento da percepção de valor e fidelização de marca. Revista Escola de Negócios, v. 2, n. 1, p. 77-105, 2014. 
ZUDHAKAR, M. Z.; SHETTY, M. S. An E-MultiSensory Brand Experience and its Effect on Consumer Behavior. SIFMAR Research Review, v. 9, n. 2, p. 5762, 2014. 


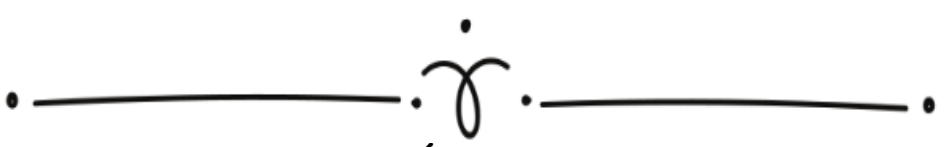

\title{
CAPÍTULO 10
}

\section{PLANEJAMENTO ESTRATÉGICO COM BASE NO NEUROMARKETING}

\author{
Izabela Souza da Silva \\ Maria Goretti Fernandes \\ José Jailton Ribeiro \\ Ana Gabriela Lopes Fernandes
}

Silvia Pessoa de Freitas Pedrosa de Oliveira

\section{INTRODUÇÃO}

A seguir você irá estudar a respeito do planejamento estratégico levando-se em consideração a base do neuromarketing. Para isso é preciso que você possa compreender antes de mais nada, o processo de planejamento estratégico do marketing.

Quando um profissional de marketing não sabe o que é a uma estratégia e para que ela serve, ele provavelmente não obterá sucesso em suas ações. Alguns profissionais de marketing não sabem desenvolver estratégias baseadas no neuromarketing, pois desconhecem o que são estratégias e como desenvolver uma metodologia eficaz para utilizá-las.

\subsection{Os fundamentos das estratégias de marketing}

Desse modo, faz-se necessário conhecer o marketing e suas particularidades, para que se possa 
entender, formular e implementar as estratégias de neuromarketing, pois no mercado consumidor as estratégias são métodos para superar os concorrentes de uma empresa.

Segundo Ansoff (1977), o conceito de estratégia tem a sua origem histórica na arte militar, onde foi utilizado para a aplicação de forças em grande escala contra os inimigos. A estratégia se opõe a tática, que é um esquema específico de emprego dos recursos disponíveis utilizados tanto em situações militares quanto empresariais.

Outro autor conhecido como Porter (1986) definiu que a estratégia é o processo de criação de uma posição exclusiva e de valor envolvendo diversas atividades. Ele considera que a estratégia é um sinônimo de escolha, devendo a organização definir quais os clientes ela quer satisfazer e suas necessidades.

No ano 2000, os pesquisadores Mintzberg, Ahlstrand e Lampel, definiram a estratégia com a ajuda de termos conhecidos como: plano, padrão, posição, perspectiva e truque. Sendo descritos da seguinte maneira:

1) A estratégia vista como um plano: direção, guia ou curso de ação para o futuro, referindo-se ao que se pretende desenvolver. É conhecida como estratégia pretendida, o que quer dizer que nem sempre será realizada;

2) A estratégia vista como um padrão: consistência de ações ao longo do tempo, referindo-se ao que já foi realizado. É conhecida como estratégia realizada;

3) A estratégia vista como uma posição: leva em consideração a localização de determinados produtos em 
determinados mercados. Como posição, a estratégia olha para o ponto em que o produto encontra o cliente, assim como para fora, pois também olha para o mercado;

4) A estratégia vista como uma perspectiva: foca na forma fundamental de uma organização fazer as coisas Como perspectiva, a estratégia olha para dentro da organização, para os estrategistas, mas também para a grande visão da empresa;

5) A estratégia vista como um truque: algo para enganar ou distrair um concorrente ou oponente, sem a intenção real de realizá-la.

Já para Simões (1983), a estratégia sofre a influência de um fator muito importante que é o ambiente, pois a organização e suas práticas estão inseridas nele. Para o autor, como o ambiente se modifica constantemente, oferecendo oportunidades e ameaças, a estratégia, no contexto competitivo, constitui-se em algo extremamente dinâmico, ou seja, que apresenta constantes mudanças, adaptações e reformulações com o objetivo de levar a organização prosperidade.

Já Kotler (2005) defende o conceito para marketing estratégico como uma ação a qual indivíduos e grupos conseguem o que desejam através da criação de oferta, venda de produtos ou serviços para se desenvolverem de forma estratégica e consolidada no mercado. Para o autor, o marketing é utilizado como uma ferramenta estratégica, utilizado pelas as organizações quando segmentam o mercado, assim analisando e identificando fatores estratégicos que são mais adequados para atingirem seus 
objetivos, com valor e ao mesmo tempo, satisfazer as exigências do mercado alvo.

Segundo Silva et al., (2011) abordam que o planejamento estratégico é um processo gerencial com escopo na criação e na adaptação de recursos de uma organização, diante as mudanças ocorridas no mercado de forma constantes, ou seja, isso significa se organizar, fazer planejamentos e objetivos estratégicos aproveitando as melhores oportunidades do mercado. Os referidos autores defendem que o planejamento estratégico é um instrumento indispensável para a gestão eficiente, pois quando as atividades da organização tornam-se estratégias bem definidas, elas são utilizadas para ampliar a visão macro do gestor sobre o mercado e sua organização, para buscar as melhores formas de conquistar novos clientes e se destacar no mercados.

Vale ressaltar que após uso das estratégias de marketing, torna-se necessário que a organização retorne suas atenções para os escopos de ação, em que possibilitam orientar de uma forma mais clara as equipes, de modo que os objetivos e as estratégias adotados sejam consolidadas de forma efetiva (LAS CASAS, 2001).

Todavia se faz necessário um olhar apurado sobre as estratégias escolhidas para realizarem seus propósitos na estratégia do marketing, também é necessário que tais estratégias estejam na direção de programas de ação que lhe permitam dar orientações sucintas a sua equipe contribuindo com o pensamento estratégico. Que desse modo à empresa possa formular suas estratégias em uma perspectiva do neuromarketing. Assim entendendo melhor 
o que faz um consumidor preferir uma marca, compra ou não um produto e como fidelizar um cliente.

\section{Você pode se perguntar nesse exato momento, onde estão inseridas as estratégias de marketing nas empresas?}

Os estudiosos Nickels e Wood (1999) descreveram que as estratégias poderiam ser realizadas em três níveis dentro de uma empresa: corporativo, de negócio e funcional. $\mathrm{O}$ nível corporativo é aquele que estabelece a direção geral para toda a organização, ou seja, os tipos de negócios ou mercados nos quais ela estará presente. Enquanto o nível de negócio visa estabelecer a direção para a forma como um negócio será administrado. Já o nível funcional é aquele que guiará as atividades de marketing, finanças e produção.

É justamente dentro do nível funcional que são elaboradas as estratégias de marketing. Elas são um conjunto de objetivos, políticas e normas que deverão guiar os profissionais de marketing da empresa, de forma independente ou como resposta a mudanças nas condições competitivas e ambientais.

\subsection{O neuromarketing como base no planejamento estratégico}

O neuromarketing foi utilizado para causar estratégicas de efeito nos consumidores. Uma estratégia que utiliza o neuromarketing pode ser vista como um caminho, uma maneira ou uma ação estabelecida e adequada para alcançar os melhores resultados da empresa baseando 
neurocientificamente no consumidor. As empresas utilizam o neuromarketing em suas estratégias, associando seus recursos físicos, financeiros e humanos para a minimização de seus problemas e a maximização de suas oportunidades (OLIVEIRA, 2004).

Para Blessa (2011), as estratégias de neuromarketing que exploram os cinco sentidos dos consumidores quebram a padronização imposta pelo marketing tradicional, repassando ao próprio consumidor a ideia de respeito à individualidade de suas preferências.

Ao empregar o neuromarketing em seu planejamento estratégico a empresa tem como propósito entender como os estímulos sensoriais influenciam os consumidores. Essa estratégia é de extrema importância para as empresas que têm como objetivo impactar positivamente o consumo e aumentar as vendas. As mensagens subliminares, por exemplo também podem ser utilizadas no planejamento estratégico de algumas empresas (MATTAR, 1999).

Kotler e Keller (2006) defendem que a Teoria Motivacional de Freud os indivíduos não percebem e nem conhecem seus próprios desejos, com isso, a consciência é concebida como reclusa do inconsciente, sendo esta o inconsciente a verdadeira fonte dos desejos e o que leva o comportamento humano. São justamente no inconsciente que estão as lembranças de cheiros, imagens, emoções, aprendizados, entre outras coisas que conduzem o público à determinada ação. Esse processo inconsciente juntamente com o consciente que surgem as experiências de 
determinadas pessoas, que criam e formam suas decisões e opiniões sejam ela individuais ou coletivas

Em uma experiência realizada em 50 lojas de departamentos e supermercados dos Estados Unidos, as empresas tocaram músicas que continham a seguinte mensagem: Eu sou honesto, e não vou roubar, 150 vezes por minuto em um tom extremamente baixo. $\mathrm{O}$ resultado foi positivo, a quantidade de furtos caiu para $37 \%$. Em outro teste, as empresas trocaram as mensagens para: Comprar é bom, observou-se então que as vendas aumentaram em aproximadamente $15 \%$. Outro exemplo dos efeitos da estratégia neuromarketing está explícito no público infantil (KOTLER, 2002).

As crianças são um exemplo de segmentação de mercado onde se podem utilizar no planejamento estratégico baseado no neuromarketing. Estudos realizados observaram que cada vez mais cedo as crianças tomam decisões de compra sem intervenção dos adultos nas lojas e em shoppings. As pesquisas realizadas em 1989, nos Estados Unidos, indicaram que $30 \%$ das crianças já estavam agindo dessa forma (FURNHAM; GUNTER; WALSH, 1998).

Faz um certo tempo que a mídia passou a ser o primeiro fator da construção da nossa subjetividade e dos nossos valores, antes dela essa construção era adquirida pela família, pela igreja e pela escola, quem influenciavam primeiramente na opinião de uma pessoa. $\mathrm{O}$ mercado infantil no Brasil movimenta 130 bilhões de reais em um ano (LACOMBE; HEILBORN, 2003). 
Segundo Furnham, Gunter e Walsh (1998) quando as crianças começam a se comunicar, elas tentam influenciar nas decisões de compra da família. Existindo três maneiras diferentes observadas: sendo influenciadas por outros membros da família; podem agir tomando decisões autonomamente e; podem influenciar as decisões de outros membros da família.

As estratégias de neuromarketing utilizadas pela mídia tem um forte papel nas decisões das crianças. Mas para que os pais atendem aos pedidos das crianças, existe uma preocupação dos mesmos quanto ao bem-estar da criança, buscando-se por produtos que contribuam para sua evolução cognitiva e pessoal, tais como: brinquedos educativos e alimentos saudáveis. Há também o empecilho econômico que pode afetar esta decisão. A maior parte dos pais querem satisfazer todos os pedidos dos filhos, mas devido a limites econômicos e ao impacto no bem-estar da criança, não o fazem. Algumas evidências indicaram que os pais podem ser menos suscetíveis de comprarem um item quando sentem que o pedido foi originado por uma influência por meios de comunicação (ROCHA; CHRISTENSEN, 1987; FURNHAM; GUNTER; WALSH, 1998).

Uma pesquisa efetuada mostrou que as crianças que viam muita televisão mostravam-se mais suscetíveis de pedirem os produtos publicitados do que espectadores menos frequentes, sendo a insistência das mesmas um modo para conseguirem o que almejam. Um estudo americano demonstrou que a principal fonte de informação das crianças de ideais para presentes era a publicidade 
televisiva (27\% das vezes), quase igualmente importante foram os amigos (26\%), seguidos pelas lojas (22\%) e, em seguida, pelos catálogos (15\%) (ADLER et al., 1980).

Para Furnham, Gunter e Walsh (1998), os fatores para o envolvimento da criança na mensagem publicitada envolve duas áreas: fatores pessoais, tais como a motivação, as atitudes em relação ao anúncio, a influência dos pais e dos colegas, ou a falta de conhecimento sobre o anúncio; e os fatores de estímulos, tais como: o contexto dos programas, se os anúncios são aborrecidos ou interessantes, o real conteúdo do anúncio e o produto publicitado (ROCHA; CHRISTENSEN, 1987).

Desse modo, o uso de planejamento estratégico baseado em neuromarketing em anúncios televisivos para crianças na maioria das veze atinge os resultados esperados. A eficácia da estratégia é baseada nos princípios da neurociência, uma vez que a mente da criança que assiste aos programas não compreende quando se inicia e quando se dá fim a publicidade na programação televisiva e, consequentemente, esta fica bastante vulnerável aos apelos da mídia (MATTAR, 1999).

Essas estratégias de neuromarketing partem das evidências científicas, pois a mente da maior parte das crianças ainda não é capaz de saber diferenciar entre um programa de televisão e um anúncio. Elas também não compreendem as intenções persuasivas da publicidade ficando altamente vulneráveis aos anúncios e tornando-se um alvo fácil.

\section{O que vimos neste conteúdo?}


- Alguns profissionais de marketing não sabem desenvolver estratégias baseadas no neuromarketing, pois desconhecem o que são estratégias e como desenvolver uma metodologia eficaz para utilizá-las;

- $\quad$ O conceito de estratégia tem a sua origem histórica na arte militar, onde foi utilizado para a aplicação de forças em grande escala contra os inimigos;

- Ao empregar o neuromarketing em seu planejamento estratégico a empresa tem como propósito entender como os estímulos sensoriais influenciam os consumidores;

- $\quad$ As estratégias de neuromarketing que exploram os cinco sentidos dos consumidores quebram a padronização imposta pelo marketing tradicional.

\section{Leitura complementar}

KISIL, M.; PUPO, T. R. G. B. Gestão da mudança organizacional. São Paulo: Faculdade de Saúde Pública da Universidade de São Paulo, 1998. (Série Saúde \& Cidadania).

KOTLER, P. Administração de marketing: a edição do novo milênio. 10. ed. São Paulo: Prentice Hall, 2000.

Como complemento dessa temática você deverá procurar ler as recomendações da leitura complementar dessa temática.

\section{REFERÊNCIAS}


ADLER, R. P. et al. The effects of television adversing on children. Toronto: Lexington Books, 1980.

ANSOFF, H. I. Estratégia empresarial. São Paulo: McGraw Brasil, 1977.

BLESSA, R. Merchandising no ponto-de-venda. 4. ed. São Paulo: Atlas, 2011.

FURNHAM, A.; GUNTER, B.; WALSH, D. Effects of Programme Context of Memory of Humorous Television Commercials. Applied Cognitive Psychology, v. 12, p. 555-567, 1998.

KOTLER, P. Administração de marketing: análise, planejamento, implementação e controle. 5. ed. São Paulo: Atlas, 1998.

KOTLER, P. Marketing essencial: conceitos, estratégias e casos. São Paulo: Pearson Prentice Hall, 2005.

KOTLER, P. Marketing para o século XXI: Como criar, conquistar e dominar mercados. São Paulo: Futura, 2002.

KOTLER, P.; KELLER, K. Administração de Marketing. 12. ed. São Paulo: Prentice Hall Brasil. 2006.

LACOMBE, F.; HEILBORN, G. Administração: princípios e tendências. São Paulo: Saraiva, 2003.

LAS CASAS, A. L. Plano de Marketing para pequena e micro empresa. São Paulo: Atlas, 2001. 
MATTAR, F. N. Pesquisa de marketing: metodologia, planejamento. 5. ed. São Paulo: Atlas, 1999.

MINTZBERG, H.; AHLSTRAND, B.; LAMPEL, J.

Safári de estratégia: um roteiro pela selva do planejamento estratégico. Porto Alegre: Bookman, 2000.

NICKELS, W. G.; WOOD, M. B. Marketing:

relacionamentos, qualidade, valor. Rio de Janeiro: LTC, 1999.

OLIVEIRA, D. P. R. Planejamento estratégico:

conceitos, metodologia e práticas.

20. ed. São Paulo: Atlas, 2004.

PORTER, M. Estratégia competitiva: técnicas para análise de indústrias e da concorrência. Rio de Janeiro: Campus, 1986.

ROCHA, A. da; CHRISTENSEN, C. Marketing: teoria e prática no Brasil. São Paulo: Atlas, 1987.

SILVA, H. H. et al. Planejamento estratégico de marketing. 4. ed. Rio de Janeiro: FVG, 2011.

SIMÕES, R. Marketing básico. São Paulo: Saraiva, 1983. 


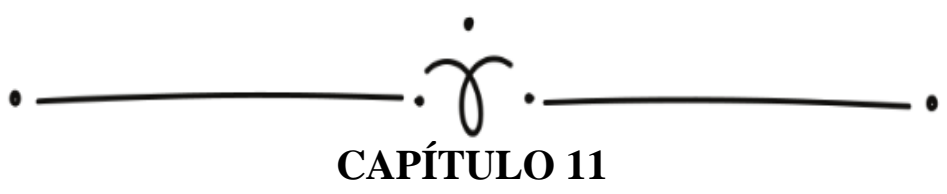

\section{INFORMAÇÃO E ESTIMULAÇÃO DO NEUROMARKETING NA INTERNET}

Izabela Souza da Silva

Maria Goretti Fernandes

Ana Gabriela Lopes Fernandes

Silvia Pessoa de Freitas Pedrosa de Oliveira

\section{INTRODUÇÃO}

No presente capítulo iremos discutir sobre a informação e estimulação do neuromarketing através da internet. A escolha dessa temática é devido ao crescimento do comércio eletrônico e o aumento dos consumidores que passaram a comprar pelos sites e aplicativos, principalmente agora com o início da Pandemia.

Nesse conteúdo iremos abordar o comportamento do consumidor que utiliza a internet e as suas motivações para comprar. Além disso, o assunto será descrito com base nos fundamentos do neuromarketing e como as suas dimensões podem tornar os websites atrativos.

\subsection{O comércio eletrônico e seu impacto no consumidor}

Nos últimos tempos a internet proporcionou ao consumidor virtual mais acesso e melhor informação sobre os produtos, os preços e os concorrentes. O comércio eletrônico cresceu e eliminou barreiras geográficas e 
temporais, na medida em que a compra passu a ser realizada em qualquer lugar e a qualquer hora. Atualmente qualquer produto passou a ter alcance em um número elevadíssimo de potenciais consumidores, em qualquer parte do mundo (GERTNER; DIAZ, 1999).

Para tentar explicar o comportamento do consumidor tem sido realizados várias pesquisas e algumas fazem referências a compras online propriamente ditas, outras procuram apenas explicar as razões e os motivos que levam à navegação pela internet. Todavia, apesar dos esforços realizados ainda existe muito para se descobrir acerca do consumidor virtual, no que diz respeito às suas características e aos seus comportamentos (LOHSE; BELLMAN; JOHNSON, 2000).

Muitos dos estudos baseiam-se apenas nas variáveis demográficas, entretanto outras pesquisas vem apontando que o processo de tomada de decisão do consumidor virtual é muito mais complexo. Por isso, não basta tentar conhecer esse consumidor apenas com base num perfil demográfico, mas é preciso estudar as suas características fundamentadas em critérios tradicionais de segmentação e ligados às variáveis da sua personalidade (UNDERHILL, 2008).

O surgimento da internet e do comércio eletrônico fez com que muitas questões fossem levantadas, em decorrência do potencial que este novo canal de distribuição oferece. Isso porque a internet abriu as portas das empresas para um mundo inteiro de possíveis clientes à distância de maneira rápida e fácil (LOHSE; BELLMAN; JOHNSON, 2000). 


\section{Qual é o impacto atual da tecnologia nas relações de consumo?}

$\mathrm{Na}$ modernidade atual, a tecnologia $\mathrm{e}$ as metodologias relacionadas com o comércio eletrônico possuem um impacto significante na forma como os negócios são efetuados. Hoje a maior parte das empresas estão presentes na internet, e contactam diretamente com seus clientes pelos websites e lojas online, disponibilizando informações acerca de seus produtos e promoções. Com os avanços da tecnologia e o crescimento significativo das diferentes áreas que integram o marketing, os canais de distribuição de produtos também sofreram alterações e consequentemente o próprio consumidor evoluiu. Se até há algum tempo atrás se utilizava somente um canal de distribuição, hoje ele utiliza vários canais (UNDERHILL, 2008).

\section{Com a chegada da internet como ficaram as relações de consumo e como o consumidor passou a ser estimulado?}

A internet chegou para revolucionar o comércio e trazer grandes alterações nas relações entre empresas e consumidores. A chegada da globalização pela internet provocou uma modificação no comportamento do consumidor, e com isso surgiu uma maior necessidade de conhece-lo, para perceber as suas atitudes e comportamentos de compra, assim como, analisar os estímulos que o influenciam. A internet passou a ser um canal onde não existe contato direto entre o vendedor e o comprador. Para o uso do neuromarketing sensorial, o uso 
dos cinco sentidos ficou restringido, mas com o passar do tempo o sentido da visão e da audição passam a ter um papel principal na comunicação (CAMARGO, 2010).

Ao analisarmos o comércio eletrônico, na ótica das empresas, este canal de distribuição veio trazer uma redução de custos de investimento, relacionados com a estrutura física de apoio ao negócio, potenciando a expansão para mercados externos (DEGERATU; RANGASWAMY, 2000).

\section{Mas será que existe algum ponto negativo no comércio através da internet?}

Sim. Apesar de todos os aspectos positivos das compras pela internet serem largamente reconhecidos, mesmo assim, existem desvantagens ligadas ao comércio eletrônico. Por exemplo, para os consumidores ditos tradicionais, podem existir problemas relacionados com a garantia de segurança nos sistemas, fiabilidade, normas e protocolos de comunicação, uma vez que os processos ligados às compras online são relativamente novos para muitos compradores (GERTNER; DIAZ,1999).

Além disso, a inexistência de uma relação física com o vendedor e a empresa, pode despertar o sentimento de desconfiança em pessoas pouco habituadas a realizar este tipo de transações pela internet. Para este tipo de consumidor existe um risco acrescido e alguns aspectos podem reforçar a pessoa a este tipo de percepção, tais como: a falta de oportunidades para examinar os produtos, as dificuldades na devolução de produtos não conformes e o receio de falta de segurança ou falta de confidencialidade 
relativamente a informações transmitidas. Muitos dos autores que escreveram acerca do comércio eletrônico, identificaram a relação negativa entre compras pela internet e a importância dada pelos consumidores a uma experiência sensorial com os produtos antes da compra. Isto pode já foi explicado por uma característica individual que os consumidores têm e que consiste na necessidade de tocar o produto, através de seu sentido tátil (LOHSE; BELLMAN; JOHNSON, 2000).

Nesse sentido o neuromarketing vem tentado explicar o comportamento de compras online a partir de três grandes grupos de conceitos: o perfil do consumidor, a forma como usa a internet e as atitudes que tem em relação à compra online. No entanto, estes pressupostos necessitam de análises mais amplas que possibilitariam gerar conhecimento e modelos mais abrangentes, capazes de melhor explicar o comportamento do consumidor online, mas que englobem estas três dimensões que já fazem parte dos vários modelos de comportamento do consumidor.

\subsection{Motivações do consumidor nas compras pela internet}

Um bom indicador do comportamento de compras online, é como as pessoas interagem com a internet e as suas motivações de compras. Alguns dados mais concretos podem avaliar este comportamento, tanto pelo número de conexões por dia realizadas, como por outros aspectos motivacionais desse uso, tais como benefícios procurados. Esse tipo de comprador tem características específicas, como sendo pessoas que passam muito tempo conectadas à 
rede, que recebem muitos e-mails por dia, que utilizam a internet para obter informações sobre os produtos e serviços e que passam razoável quantidade de horas ligados (LOHSE; BELLMAN; JOHNSON, 2000).

As motivações que impulsionam o uso e a compra pela internet apresentam-se divididas nos seguintes grupos: benefícios utilitários (comunicação, busca de informações, conveniência, fatores econômicos) e benefícios hedonicos (divertimento, passar o tempo, relaxamento, conviver com amigos, participar de comunidades (GERTNER; DIAZ,1999).

A expansão do comércio eletrônico estimulou o aumento do número de pesquisas, com o intuito de descobrir o que mais tem atraído os consumidores, tanto no que diz respeito ao próprio consumidor como também à tecnologia, abordando cada uma das visões num mesmo contexto. No que diz respeito à visão orientada aos consumidores, estudam-se as suas crenças sobre compras on-line, visto que estas podem influenciar a seleção do canal de compra. Analisa-se qual a importância de determinados fatores como características demográficas, psicológicas e cognitivas, percepção do risco e benefícios em relação à compra on-line, motivação e orientação para compra (ZHOU; DAI; ZHANG, 2007).

Levando-se em conta que o Neuromarketing estuda essencialmente as respostas cognitivas aos estímulos, e que leva em conta, os processos automáticos e instintivos, tal como a motivação e as emoções, para a dimensão: motivação no ambiente virtual. $\mathrm{O}$ modelo proposto que 
justamente se enquadra na dimensão da motivação, parte dos seguintes pressupostos constantes na figura abaixo:

Existem alguns atributos que são fundamentais para a avaliação positiva da qualidade de um website. Sendo a qualidade um atributo muito subjetivo, e muito difícil de medir, pois não existe um modelo único para medir a qualidade de um website. Dos itens considerados para este modelo, leva-se em conta as seguintes dimensões da qualidade:

- Navegabilidade: é articulação que o sujeito faz entre as suas competências (conhecimentos e habilidades), os objetivos que ele tem ao visitar um website (serviços ou informações), além das condições que cada página do website pode oferecer para o usuário atingir tais objetivos. Os princípios da navegabilidade devem levar em conta links e conteúdos facilmente acessíveis, simples para o usuário, devem estar identificados como ligações e estas devem direcionar para o conteúdo anunciado (ABRAHÃO; SILVINO, 2003).

- Usabilidade: pode ser definida como o termo técnico usado para descrever a qualidade de uso de uma interface. Pode estar associada a alguns princípios como a facilidade de aprendizagem, a facilidade de recordar como realizar determinada tarefa algum tempo depois, a rapidez no desenvolvimento de tarefas, a baixa taxa de erros e a satisfação subjetiva do usuário;

- Legibilidade: um website que se possa considerar de sucesso deve ter um esquema de cores coerente, que não 
seja visualmente cansativo para quem o visita, devendo seus conteúdos serrem fidedignos e claros;

- $\quad$ Rapidez: a velocidade de um website pode depender de vários fatores, nomeadamente o servidor onde o website está alojado, a velocidade da internet do utilizador, a capacidade de processamento do computador, o navegador escolhido e o peso do website. Deve-se evitar um conteúdo desnecessário que poderá tornar o website lento, e este é um dos principais fatores que leva os usuários a fecharem websites em que nos dez primeiros segundos não se consiga visualizar o seu conteúdo;

- Interatividade: a extensão em que os utilizadores podem participar modificando a forma e o conteúdo em tempo real. Um bom website deve ter um espaço para dar voz aos seus clientes, deixando que participem com sugestões, críticas, ou criando e compartilhando experiências com a marca (STEUER, 1992);

- $\quad$ Funcionalidade: um bom website deverá funcionar em qualquer navegador, não criando barreiras ao usuário;

- $\quad$ Layout: este aspecto tem uma grande importância no envolvimento do consumidor com a marca e pode ser um fator determinante no que diz respeito à decisão de compra. O layout deve ser a imagem da empresa e estar de acordo com a personalidade da marca. A combinação de cores, a escolha de imagens de qualidade são aspectos importantes a serem levados em conta. O layout deve tornar o website simples e claro para o usuário, de fácil compreensão, com a 
informação colocada de forma atrativa, tornando a navegação mais fácil. Um consumidor que se sinta confuso com o layout, ou que não encontre o que procura nos primeiros segundos em que entra no site, tem grandes probabilidades de deixar o site nos segundos seguintes.

Desse modo, o neuromarketing quando é aplicado para o comércio eletrônico deve procurar prever o comportamento do consumidor virtual por meio da análise técnica das especificações das lojas virtuais, que incluem como já vimos a interface do utilizador, o conteúdo, o design do website e usabilidade do sistema, entre outras. O sucesso das lojas virtuais acontece quando as mesmas conseguem atingir todos esses requisitos com base nas estratégias de neuromarketing, levando ao consumidor a aumentar as suas compras pela internet.

\section{O que vimos neste conteúdo?}

- Nos últimos tempos a internet proporcionou ao consumidor virtual mais acesso e melhor informação sobre os produtos, os preços e os concorrentes.

- $\quad$ O comércio eletrônico cresceu e eliminou barreiras geográficas e temporais, na medida em que a compra passu a ser realizada em qualquer lugar e a qualquer hora.

- $\quad$ As motivações que impulsionam o uso e a compra pela internet são: benefícios utilitários (comunicação, busca de informações, conveniência, factores económicos) e benefícios hedonicos (divertimento, passar o tempo, 
relaxamento, conviver com amigos, participar de comunidades.

- Quando o neuromarketing é aplicado ao comércio eletrônico, o mesmo deve promover qualidade na interface do utilizador, no conteúdo, no design do website e na usabilidade do sistema.

\section{Leitura complementar}

LINDSTROM, M. A lógica do consumo: verdades e mentiras sobre porque compramos. Rio de Janeiro: Harper Collins Brasil, 2016.

TURBAN, E.; MCLEAN, E.; WETHERBE, J. Tecnologia da informação para gestão: transformado os negócios da economia digital. Rio de Janeiro: Bookman, 2004.

A leitura complementar acima é recomendada para ampliar os conhecimentos do aluno sobre os assuntos abordados nessa temática.

\section{REFERÊNCIAS}

ABRAHÃO, J. I.; SILVINO, A. M. D. Navegabilidade e inclusão digital: usabilidade e competência. RAE Electrônica, São Paulo, v. 2, n. 2, p. 1-17, jul./dez. 2003.

CAMARGO, P. de. Comportamento do consumidor: a biologia, anatomia e fisiologia do consumo. Ribeirão Preto: Novo Conceito, 2010. 


\section{DEGERATU, A. M.; RANGASWAMY, A.; WU, J.}

Consumer choice behavior in online and traditional supermarkets: The effects of brand name, price, and other search attributes. International Journal of Research in Marketing, v. 1, n. 1, p. 55-78, 2000.

GERTNER, D.; DIAZ, A. Marketing na internet e comportamento do consumidor: investigando a dicotomia hedonismo vs. utilitarismo na WWW. RAC - Revista de Administração Contemporânea, Rio de Janeiro, v. 3, n. 3, p. 131-156, 1999.

LOHSE, G. L.; BELLMAN, S.; JOHNSON, E. J. Consumer Buying Behavior on the Internet: Findings From Panel Data. Journal of interactive Marketing, v. 14, n. 1 , p. 15-29, 2000.

STEUER, J. Defining virtual reality: dimensions determining telepresence. Journal of Communication, v. 42, n. 4, p. 72-93, 1992.

UNDERHILL, P. A ciência das compras: tudo o que sempre quis saber sobre o comportamento dos consumidores. Lisboa: Gestãoplus, 2008.

ZHOU, L.; DAI, L.; ZHANG, D. Online shopping acceptance model - a critical survey of consumer factors in online shopping. Journal of Electronic Commerce Research, v. 8, n. 1, p. 41-62, 2007. 


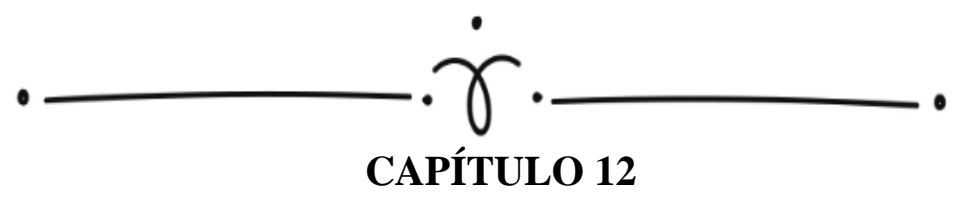

\title{
NEUROMARKETING NAS ÁREAS DO CONHECIMENTO (EDUCAÇÃO E SAÚDE)
}

\author{
Izabela Souza da Silva \\ Maria Goretti Fernandes \\ José Jailton ribeiro \\ Ana Gabriela Lopes Fernandes
}

\section{INTRODUÇÃO}

As áreas do conhecimento que mais tem utilizado o neuromarketing são: a educação e a saúde. Para melhor compreender como essas áreas estão fazendo uso dessa ferramenta, iniciaremos a discussão pela perspectiva da neurociência na saúde.

É importante lembrar que ao longo dos temas abordados verificamos uma grande revolução trazida pelos avanços da neurociência nas diversas áreas e a sua ampla utilização pelo neuromarketing. Este fato pode ser percebido por recentes associações entre as neurociências e outras áreas de estudo, entre elas as áreas da saúde e da educação. Nos conteúdos que se seguem abaixo iremos descrever sobre alguns estudos relacionados ao neuromarketing nessas áreas de conhecimento.

\subsection{Neurociência versus neuromarketing na saúde}


Uma vez que o neuromarketing passa a ser visto pela saúde e educação, como uma ciência aplicada ao consumo, e por isso é de grande valia para o entendimento da influência de pistas sensoriais, a geração de desejo, e o ato de consumir, e a satisfação derivada do consumo em qualquer área. A possibilidade de utilização dos conhecimentos neurocientíficos para aplicações práticas na área da saúde para o benefício humano. São oportunidades reais existentes de transferência do conhecimento acadêmico construindo novas soluções que possibilitem um melhoramento da sociedade poderão transformar o mundo e a vida das pessoas. A partir de agora, você verá exemplos de como a neurociência e o neuromarketing estão influenciando a saúde.

É preciso lembrar que alguns termos têm sido associados a neurociência, tais como neurorobótica, neuroergonomia, neuroarquitetura e neurotecnologia. No meio desta grande inserção de novos conceitos, uma grande transformação está ocorrendo na área da saúde, uma vez que a mesma está utilizando o neuromarketing em suas campanhas educativas, no apelo ao comércio dos planos de saúde, no mercado de clínicas, consultórios e hospitais, entre outras questões ligadas a saúde das pessoas (GISZTER et al., 2001; PARASURAMAN; WILSON, 2008; EBERHARD, 2009; LYNCH, 2004).

Lembre-se que a aplicação das metodologias do neuromarketing podem não só auxiliar as empresas no conhecimento do comportamento do consumidor, mas também seguimentos ligados a outras áreas como a saúde. Estes estudos podem, por exemplo, revolucionar 
campanhas governamentais que objetivem mudanças de atitudes e comportamentos na população em direção a escolhas saudáveis. Sendo de extrema importância para os governos, a adoção de estilo de vida saudável, podendo exercer papel social e econômico de extrema importância.

\subsection{O exemplo da influência do neuromarketing em uma questão de saúde}

Existe diversas preocupações governamentais sobre a saúde da população, há muitos anos o tabagismo detém extrema relevância, pois é considerado como um dos subtipos de transtorno mental e comportamental ao uso de substância psicoativa (WHO, 2004). Ademais, é também considerado como uma epidemia mundial (WHO, 2008).

A indústria do tabaco por muitos anos tem utilizado os meios de comunicação de massa e intensa campanha publicitária para influenciar as pessoas para que se tornem dependentes (PIERCE; GILPIN, 2001; BORLAND; BALMFORD, 2003). Ao longo dos anos, as campanhas de saúde pública de controle do tabaco têm contra atacado as investidas da indústria tabagista com considerável sucesso (BORLAND; BALMFORD, 2003; HAMMOND et al., 2006).

As estratégias destas campanhas envolvem um vasto espectro de ações que objetivaram a prevenção da população em relação à dependência, como também ações que estimulem os fumantes a deixarem de fumar (WAKEFIELD et al., 2003). Estas políticas foram sistematizadas e unificadas através de um esforço conjunto entre diversos países. Foi assim que nasceu o primeiro 
tratado mundial no âmbito da saúde negociado sob os auspícios da Organização Mundial da Saúde.

A convenção para controle do tabaco foi um dos tratados de maior adesão na história das Nações Unidas, tendo hoje 171 países que seguem a mesma. Em suas diretrizes, a convenção estabeleceu uma série de regulamentos estratégicos para conter a epidemia tabagista, como aumento de impostos sobre produtos, proteção à fumaça dos cigarros (fumo passivo), banimento de qualquer tipo de propaganda ao cigarro, políticas de prevenção para os jovens, apoio aos dependentes e esclarecimento acerca das consequências do uso do tabaco (WHO, 2005).

Um bom exemplo da influência do neuromarketig na questão do tabagismo foi a criação de rótulos com advertências visuais desagradáveis podem ter um impacto bem sucedido em consumidores destes produtos, especialmente para aqueles que estão em experimentação ou para os que estão desejando deixar o vício, se as advertências forem bem visíveis e advirtam também sobre os efeitos negativos do tabagismo (DONOVAN et al., 2003).

De fato, se um fumante fuma 20 cigarros por dia, ele manipulará o maço 7.300 vezes em um ano, índice dificilmente alcançado por outro tipo de mídia. Entretanto, muito pouco é conhecido sobre os mecanismos pelos quais este tipo de campanha tem efeito. Além disto, pesquisas sobre o impacto motivacional das advertências podem se beneficiar de abordagens experimentais multidisciplinares (BAKER; BRANDON; CHASSIN, 2004; NETEMEYER; ANDREWS; BURTON, 2005). 
Nesse exato momento você pode se perguntar: será que imagens desagradáveis podem interferir na mudança de hábitos das pessoas?

Sim. Isso mesmo, símbolos de ameaça, imagens aversivas podem gerar diversos padrões de reações emocionais. No entanto, estes símbolos podem variar na percepção de intensidade proporcionada e desta forma influenciarem diferentemente a ativação de motivações aversivas. Dentre as diferentes categorias de fotografias desagradáveis, as que detêm alto conteúdo de ativação são as que se remetem a conteúdos mais ameaçadores de uma perspectiva de sobrevivência (ex: corpo de mutilados, ataque humano, ataque animal). Ao se introduzir estímulos visuais desagradáveis nos maços de cigarro, pode-se esperar que estes promovam uma ativação dos circuitos motivacionais ligado a esquiva, evitando o consumo de seu conteúdo, sendo estes seriam os objetivos primordiais das ações de controle do tabaco (HAMMOND et al., 2006).

Estudos dos circuitos cerebrais que provocam reações defensivas revelam que estímulos aversivos engajam uma rede subcortical de estruturas incluindo a amígdala cerebral em humanos. Imagens aversivas também ativam áreas cerebrais envolvidas no processamento visual e motor, além de proporcionar fortes respostas autonômicas (ex: bradicardia e aumento da sudorese palmar), somáticas e hormonais (PHELPS; LEDOUX, 2005; MOURAOMIRANDA et al., 2003; PEREIRA et al., 2010; CODISPOTI et al., 2003). 
Estudos de nosso grupo revelaram também reações comportamentais claras, como a postura de congelamento (freezing-like posture) à visualização de corpos mutilados e interferências em tarefas comportamentais pela visualização da mesma categoria de fotografias (AZEVEDO et al., 2005; FACCHINETTI et al., 2006; PEREIRA et al., 2006).

Em tabagistas, pistas visuais relativas ao fumo engajam a atenção de maneira rápida, automática e seletiva, através de reações implícitas diferenciadas em relação aos não-tabagistas (HOGARTH; DICKINSON; DUKA, 2003). Além disto, respostas afetivas implícitas medidas pela intensidade de piscar no reflexo de sobressalto, mostraram que imagens contendo pistas visuais relacionadas ao tabaco inibem este reflexo defensivo, indicando uma maior ativação do sistema apetitivo (DEMPSEY et al., 2007).

Um grande número de pesquisas em neurobiologia da emoção ter demonstrado que estímulos visuais emocionais afetam a atitude e o comportamento; e que a habilidade de exercer controle consciente e voluntário sobre o planejamento e engajamento em ações é bastante limitada; e que estes, em grande parte, ocorrem através de mecanismos implícitos e automáticos (BARGH; CHARTRAND, 1999). Desse modo poderíamos utilizar o modelo das bases motivacionais da emoção para construção de advertências com imagens que pudesse gerar maior afastamento.

\subsection{Uso das técnicas de neuroimagem na saúde com propósitos comerciais}


Ao longo da nossa disciplina você estudou sobre as técnicas de neuroimagem e os seus avanços no estudo do cérebro humano. Como já foi relatado as técnicas de neuroimagem, como a Imagem por Ressonância Magnética Funcional (FMRI), a Tomografia por Emissão de Positrons (PET) e a Tomografia Ótica Funciona Difusa (FDOT), entre outras, podem, não só melhorar o conteúdo e a aplicação de métodos padronizados de pesquisa de mercado, como também detectar e medir as reações dos consumidores aos estímulos de marketing (BICKEL et al., 2007).

As técnicas de neuroimagem utilizadas pelo neuromarketing auxiliam aos gerentes a determinarem a eficácia de questionários de levantamento (especialmente os testes padronizados ou de levantamentos exclusivos) na avaliação de certos pensamentos e sentimentos, ampliando os conhecimentos dos gerentes acerca dos processos mentais dos consumidores. Outro ponto positivo com relação às técnicas de neuroimagem é a sua capacidade de isolar importantes metáforas, escolhidas para o desenvolvimento de determinadas propagandas ou de estratégias de posicionamento, e avaliar se a metáfora escolhida atrairá mais atenção e será mais memorável. Desse modo, o neuromarketing mostra que as análises realizadas com o consumidor estão bem mais abrangente do que aquelas realizadas anos atrás. Por isso, empresas renomadas como o Citibank e a Disney contemplam em suas áreas do conhecimento como a musicologia, neurologia, filosofia, zoologia, antropologia, psicologia e sociologia (ZALTMAN, 2003). 
A literatura aponta o neuromarketing como uma alternativa de análise do consumidor. Isto se deve ao fato de se reconhecer a importância de investigar e interpretar os processos inconscientes, psicossocial biológicas, instintivas, emocionais e intelectuais dos consumidores. Além disso, a utilização de técnicas de neuroimagem pelo neuromarketing possibilitam identificar as áreas do cérebro que são ativadas quando os consumidores são expostos a vídeos, marcas, produtos etc. (BICKEL et al., 2007).

Alguns pontos chamam a atenção sobre o desenvolvimento do neuromarketing. Embora seja um tema recente, as técnicas de neuroimagem, utilizadas com propósitos comerciais, já são discutidas em algumas universidades e aplicadas por grandes empresas automobilísticas, de refrigerantes, de varejo e de alimentos. As análises do sistema de recompensa dos indivíduos contribuem para entender o comportamento dos consumidores, suas preferências e reações a determinados sabores, cheiros ou até estímulos sociais (LEE; BRODERICK; CHAMBERLAIN, 2007; MCCLURE et al., 2004; ZALTMAN, 2003; LE COUTRE, 2007).

\subsection{Neuromarketing na educação}

A educação tem passado por muitas transformações, mas os educadores continuam difundindo os produtos e os serviços educacionais de forma desconectada com as reais demandas do seu público. Várias pesquisas em neuromarketing estão sendo desenvolvidas para a área educacional devido à importância no processo de 
aprendizagem, sendo necessário refletir sobre as tarefas cognitivas complexas do cérebro (SPRENGER, 2008).

\section{Como captar a atenção dos alunos e os fazer refletir sobre aquilo em que sua atenção se concentra mais?}

A década do cérebro foi a dos anos 90, trazendo grandes avanços tecnológicos e ferramentas que possibilitaram estudar a estrutura cerebral e seu funcionamento. As técnicas de neuroimagem como já foram ditas, possibilitaram um mapeamento do cérebro humano e trouxeram subsídios para um maior conhecimento dos mecanismos cognitivos. Esses novos conhecimentos nos possibilitam uma melhor compreensão sobre como lidamos com os alunos (SPRENGER, 2008). Existem três tipos de alunos, são eles:

1. Aprendizes visuais que prestarão uma atenção particular às informações visuais, incluindo texto;

2. Aprendizes auditivos para quem as informações tornam-se mais assimiláveis pela discussão;

3. Aprendizes cinestésicos ou táteis que aprendem melhor quando envolvem diretamente o corpo e podem precisar se "tornar" aquilo que estão aprendendo.

É importante saber que o ser humano aprende com facilidade aquilo que possibilita satisfazer alguma das suas necessidades básicas. De acordo com alguns autores, essas necessidades podem ser agrupadas em categorias, tais como: necessidades fisiológicas, necessidades de segurança, a sensação de estar inserido e ser amado, 
necessidade de estima, necessidade de auto-realização (MASLOW; LOWERY, 1998)

$\mathrm{O}$ neuromarketing educacional utiliza tais conhecimentos como recurso no desenvolvimento de tecnologias de ensino concordantes com os esquemas mentais componentes dos processos de memorização ampliada. Esses esquemas envolvem a passagem da memória de curto prazo para a de longo prazo o que poderá proporcionar a otimização do processo de ensinoaprendizagem. Desse modo, uma metodologia de ensino que utiliza adequadamente os fundamentos do neuromarketing deverá levar em consideração as algumas contribuições:

- O cérebro dos alunos do gênero feminino é diferente do masculino, logo os estímulos em sala de aula não podem ser os mesmos para ambos;

- $\quad$ Os alunos muitas vezes não sabem o que querem e muitas vezes tem medo do novo;

O sistema educativo está cheio de aspectos limitantes. É necessário entender as limitações para que haja uma transformação;

- $\quad$ As cores têm um efeito no cérebro humano, e estas apresentam influência em partes diferentes do cérebro, considerando que algumas cores terão uma reação maior em partes que favorecem o aprendizado como o pré-frontal, a exemplo do azul e do verde.

As experiências, já realizadas na área educacional, demonstram que o neuromarketing pode se tornar um 
campo com potencial para as instituições de ensino, pois, estas terão condições de obter informações mais precisas, bem como, poderão aplicar antecipadamente as estratégias de ensino ou conteúdo que serão veiculados para os alunos. Estudos podem ser feitos para mapear o nível de domínio ou aplicação dos conceitos e técnicas do neuromarketing nestes segmentos, e sugere-se que quando utilizados na área educacional poderão ser capazes de promover uma maior motivação aos alunos no processo de aprendizagem. No entanto, essa área é ainda desprovida de bibliografias e pesquisas científicas.

\section{O que vimos neste conteúdo?}

- $\quad$ No século atual as áreas do conhecimento que tem mais utilizado o neuromarketing são a educação e a saúde;

- $\quad$ O neuromarketing passa a ser visto pela saúde e educação, como uma ciência aplicada ao consumo, sendo de grande valia para o entendimento da influência de pistas sensoriais, a geração de desejo, e o ato de consumir, e a satisfação derivada do consumo em qualquer área;

- As técnicas de neuroimagem utilizadas pelo neuromarketing auxiliam aos gerentes a determinarem a eficácia de questionários de levantamento na avaliação de certos pensamentos e sentimentos;

- Várias pesquisas em neuromarketing estão sendo desenvolvidas para a área educacional devido a importância no processo de aprendizagem, sendo necessário refletir sobre as tarefas cognitivas complexas do cérebro. 


\section{Leitura complementar}

LUDOVICO, N.; SANTINI, F. R. Gestão de marketing:

O plano de marketing como orientador das decisões. São Paulo: Saraiva, 2014. (Série gestão empresarial).

PINHEIRO, D.; GULLO, J. Comunicação integrada de marketing: gestão dos elementos de comunicação. 4. ed. São Paulo: Atlas, 2013.

Aproveite a leitura complementar acima para aprender mais sobre o marketing e sua correlação com o tema estudado.

\section{REFERÊNCIAS}

AZEVEDO, T. M. et al. A freezing-like posture to pictures of mutilation. Psychophysiology, v. 42, n. 3, p. 255-260, 2005.

BAKER, T. B.; BRANDON, T. H.; CHASSIN, L.

Motivational influences on cigarette smoking. Annual Review of Psychology, v. 55, p. 463-491, 2004.

BARGH, J. A.; CHARTRAND, T. L. The unbearable automaticity of being. American Psychologist, v. 54, n. 7, p. 462-479,1999.

BICKEL, W. K. et al. Behavioral and neuroeconomics of drug addiction: Competing neural systems and temporal 
discounting processes. Drug and Alcohol Dependence, v. 90, suppl. 1, p. s85-s91, sep. 2007.

BORLAND, R.; BALMFORD, J. Understanding how mass media campaigns impact on smokers. Tobacco Control, v. 12, n. 2, p. 45-52, 2003.

CODISPOTI, M. et al. Emotional perception and neuroendocrine changes. Psychophysiology, v. 40, n. 6, p. 863-868, 2003.

DEMPSEY, J. P. et al. Appetitive nature of drug cues reconfirmed with physiological measures and the potential role of stage of change. Psychopharmacology, v. 194, n. 2, p. 253-260, 2007.

DONOVAN, R. J. et al. Continuous tracking of the Australian National Tobacco Campaign: advertising effects on recall, recognition, cognitions, and behaviour. Tobacco Control, v. 12, n. 2, p. 30-39, 2003.

EBERHARD, J. P. Applying Neuroscience to Architecture. Neuron, v. 62, n. 6, p. 753-756, 2009.

FACCHINETTI, L. D. et al. Postural modulation induced by pictures depicting prosocial or dangerous contexts. Neuroscience Letters, v. 410, n. 1, p. 52-56, 2006.

GISZTER, S. F. et al. Neurobiological and neurorobotic approaches to control architectures for a humanoid motor system. Robotics and Autonomous Systems,

v. 37, n. 2-3, p. 219-235, 2001. 
HAMMOND, D. et al. Effectiveness of cigarette warning labels in informing smokers about the risks of smoking: findings from the International Tobacco Control (ITC) Four Country Survey. Tobacco Control, v. 15, n. 3, p. 1925, 2006.

HOGARTH, L.; DICKINSON, A.; DUKA, T.

Discriminative stimuli that control instrumental tobaccoseeking by human smokers also command selective attention. Psychopharmacology, v. 168, n. 4, p. 435-445, 2003.

LE COUTRE, J. Molecular taste physiology of tongue and gut. In: NEUROSCIENCE SYMPOSIUM, 2., 2007, Natal. Anais [...]. Natal: IINN, 2007. p. 11.

LEE, N.; BRODERICK, A. J.; CHAMBERLAIN, L. What is 'neuromarketing'?

A discussion and agenda for future research.

International Journal of Psychophysiology, v. 63, issue 2, p. 199-204, feb. 2007.

LYNCH, Z. Neurotechnology and society (2010-2060). Coevolution of Human Potential and Converging Technologies, v. 1013, p. 229-233, 2004.

MASLOW, A.; LOWERY, R. Toward a psychology of being. 3. ed. Hoboken, NJ: Wiley \& Sons, 1998.

MCCLURE, S. M. et al. Separate neural systems value immediate and delayed monetary rewards. Science, v. 306, n. 5695, p. 503-507, oct. 2004. 
MOURAO-MIRANDA, J. et al. Contributions of stimulus valence and arousal to visual activation during emotional perception. Neuroimage, v. 20, n. 4, p. 1955-1963, 2003.

NETEMEYER, R. G.; ANDREWS, J. C.; BURTON, S. Effects of antismoking advertising-based beliefs on adult smokers' consideration of quitting. American Journal of Public Health, v. 95, n. 6, p. 1062-1066, jun. 2005.

PARASURAMAN, R.; WILSON, G. F. Putting the brain to work: Neuroergonomics past, present, and future.

Human Factors, v. 50, n. 3, p. 468-474, 2008. PEREIRA, M. G. et al. Emotion affects action: Midcingulate cortex as a pivotal node of interaction between negative emotion and motor signals. Cognitive, Affective, \& Behavioral Neuroscience, v. 10, n. 1, p. 94106, 2010.

PEREIRA, M. G. et al. Sustained and transient modulation of performance induced by emotional picture viewing. Emotion, v. 6, n. 4, p. 622-634, 2006.

PHELPS, E. A.; LEDOUX, J. E. Contributions of the amygdala to emotion processing: From animal models to human behavior. Neuron, v. 48, n. 2, p. 175-187, 2005.

PIERCE, J. P.; GILPIN, E. A. News media coverage of smoking and health is associated with changes in population rates of smoking cessation but not initiation. Tobacco Control, v. 10, n. 2, p. 145-153, 2001. 
SPRENGER, M. Memória: como ensinar para o aluno lembrar. Tradução de Magda França Lopes. Porto Alegre: Artmed, 2008.

WAKEFIELD, M. et al. Effects of anti-smoking advertising on youth smoking: a review. Journal of Health Communication, v. 8, n. 3, p. 229-247, may/jun. 2003.

WORLD HEALTH ORGANIZATION. ICD-10:

International statisticalclassification of diseases and related health problems. 2nd. ed. Geneva: WHO Press, 2004.

WORLD HEALTH ORGANIZATION. WHO

Framework Convention on Tobacco Control. Geneva: WHO Press, 2005.

WORLD HEALTH ORGANIZATION. WHO Report on the Global Tobacco Epidemic, 2008: The mpower package. Geneva: WHO Press, 2008.

ZALTMAN, G. Afinal, o que os clientes querem. Rio de Janeiro: Campus, 2003. 

Chawking 